Lilian Aparecida Fiorini Vermeersch

\title{
Desenvolvimento de membranas assimétricas de polieterimida e estudo comparativo pós modificação bioinspirada.
}

\section{Exemplar revisado}

O exemplar original encontra-se em acervo reservado na Biblioteca do IQSC-USP

Tese apresentada ao Instituto de Química de São Carlos da Universidade de São Paulo como parte dos requisitos para obtenção do título de Doutora em Ciências.

Área de concentração: Físico-Química

Orientador: Prof. Dr. Caio Márcio Paranhos da Silva

São Carlos 
Autorizo a reprodução e divulgação total ou parcial deste trabalho, por qualquer meio convencional ou eletrônico para fins de estudo e pesquisa, desde que citada a fonte.

AssinaturaLilian Ap. Fionini Vermeersch
Data: 11/05/2021

Ficha Catalográfica elaborada pela Seção de Referência e Atendimento ao Usuário do SBI/IQSC

Vermeersch, Lilian Aparecida Fiorini

Desenvolvimento de membranas assimétricas de polieterimida e estudo comparativo pós modificação bioinspirada. / Lilian Aparecida Fiorini

Vermeersch. - São Carlos, 2021.

$85 \mathrm{f}$

Tese (Doutorado em Físico-Química) — Instituto de Química de São Carlos / Universidade de São Paulo, 2021.

Orientador: Prof. Dr. Caio Márcio Paranhos da Silva

1. Membrana polimérica. 2. Permeção de gases. 3. Membrana assimétrica. 4. Polímeros (Materiais). I. Título.

Sonia Alves - CRB: 4280/8 
Dedico este trabalho aos meus pais Célia e Carlos. 


\section{AGRADECIMENTOS}

Ao Instituto de Química de São Carlos - USP;

Ao programa de Pós-graduação em Química da UFSCar;

Às agências de fomento CAPES, CNPq e FAPESP;

Ao Professor Dr. Caio Márcio Paranhos da Silva, orientador deste trabalho;

À Professora $\mathrm{Dr}^{\mathrm{a}}$ Sandra Andrea Cruz, integrante do grupo de pesquisa do laboratório de polímeros;

Ao Professor Benedito dos Santos Lima Neto, pelo apoio e orientação no início deste trabalho;

Ao Professor Dr. Edenir Rodrigues Pereira Filho, colaborador em importante etapa deste trabalho;

Ao Dr. Nelson Marcos Larroca, colaborador em uma das etapas experimentais deste trabalho;

Ao Dr. Danilo Martins dos Santos, conselheiro de importante etapa deste trabalho;

Ao Dr. Orlando Lima de Sousa Ferreira, pelas discussões de importantes etapas deste trabalho;

À AMADA família do laboratório de polímeros, por toda a convivência, os aprendizados, suporte e alegrias durante todo o decorrer de meu doutorado;

A todos os amigos, os de longa data e aqueles que foram surgindo durante este tempo de pósgraduação, pelo apoio e carinho recebidos. 
"Nós somos o que repetidamente fazemos. A excelência, então, não é um ato, mas um hábito" (Will Durant) 


\section{RESUMO}

Nos últimos anos os processos de separação por membranas se tornaram muito interessantes para o setor industrial. Membranas poliméricas são frequentemente empregadas nesses processos por possuírem estabilidade térmica e química, propriedades que conferem versatilidade a esses materiais. Nos processos de separação de gases, especificamente, se avalia a performance através da seletividade, que compara a permeabilidade da membrana em relação aos gases permeados. A obtenção de membranas poliméricas que atendam às necessidades de permeabilidade e seletividade, requeridas nas aplicações, ainda é um dos desafios da etapa de produção destes materiais. O presente trabalho teve como um dos objetivos investigar a influência de diferentes variáveis na produção de membranas a partir da técnica de inversão de fases. Para este fim um planejamento experimental foi empregado para delinear as condições de obtenção de membranas à base de polieterimida (PEI). Em etapa seguinte, foram procedidas caracterizações de morfologia por microscopia eletrônica de varredura, de ângulo de contato e das propriedades de transporte por permeação de vapor de água, e seletividade do par gasoso $\mathrm{O}_{2} / \mathrm{CO}_{2}$. Os resultados de permeabilidade e seletividade foram avaliados através de tratamento estatístico com a finalidade de apontar a membrana mais adequada para ser submetida a um procedimento de modificação de superfície, com o objetivo de avaliar possíveis posteriores impactos nas suas propriedades. A amostra PEI 3, que apresentou a segunda maior taxa de transporte de vapor de água e seletividade ao par gasoso $\mathrm{O}_{2} / \mathrm{CO}_{2}$ mediana, entre as membranas produzidas, se apresentou a melhor opção para ser submetida à etapa de modificação bioinspirada: recobrimento com polidopamina. As mesmas caracterizações de transporte supracitadas foram realizadas para as membranas modificadas e a avaliação da influência deste procedimento na performance da membrana foi procedido, permitindo concluir que ocorre alteração no sentido de aumento das taxas de permeação a gases e vapores.

Palavras-chave: Membrana assimétrica, membrana porosa, polidopamina, modificação bioinspirada, separação de gases. 


\begin{abstract}
In the last years membrane separation processes became markably interesting for the industry, mainly due to financial scope. Polymer membranes are frequently employed in these processes because of its thermal and chemical stability that make them versatile materials. The performance of gas membrane separation processes is proceeded through selectivity measurement, which analyse the permeability of membrane for gases. A challenge in the production of polymeric membrane is achieve good permeability and selectivity in the same material, to attend applications needs. One of the objectives of this work was to investigate the influence of production stage variables on the membranes' morphology. The method chosen was the phase inversion and an experimental design was performed to delineate the conditions to obtain membranes of polyetherimide. In the next step, the following characterizations were performed: Scanning electronic microscopy (SEM), contact angle (CA), water vapour transmission (WVT) and selectivity of the gaseous pair, oxygen $\left(\mathrm{O}_{2}\right)$ and carbon dioxide $\left(\mathrm{CO}_{2}\right)$. The results obtained for transport analysis received a statistical treatment to point the best sample to be used in the second step of this work: a bioinspired modification through surface polydopamine deposition. The sample PEI 3 that presented the second larger WVT rate and median selectivity was chosen for this purpose. Finally, the results of selectivity transport analysis of the gaseous pair oxygen $\left(\mathrm{O}_{2}\right)$ and carbon dioxide $\left(\mathrm{CO}_{2}\right)$ for non modified and modified membranes were compared. It was possible to conclude that the surface modification promotes increase in WVT rates and $\mathrm{O}_{2}$ permeance.
\end{abstract}

Keywords: Asymmetric membrane, porous membrane, polydopamine, bioinspired modification, gas separation. 


\section{LISTA DE FIGURAS}

Figura 1. Ilustração de um módulo de separação por membrana....................................................... 16

Figura 2. Representação esquemática de separação por membrana................................................... 17

Figura 3. Principais tipos de membranas poliméricas...................................................................... 19

Figura 4. Digrama de fases ternário da obtenção de membranas pelo método da separação de fases por

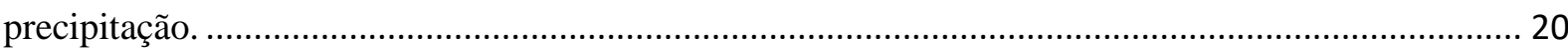

Figura 5. Representação dos mecanismos de permeação por membranas porosas.............................. 23

Figura 6. Representação da unidade monomérica de repetição do PEI. .............................................. 29

Figura 7. Esquema do equilíbrio mecânico entre uma gota em um sólido sob ação das tensões superficiais.

Figura 8 .Copo de Payne utilizado no ensaio de permeação ao vapor d'água. ..................................... 34

Figura 9. Representação esquemática da célula de permeação............................................................ 36

Figura 10. Representação esquemática do sistema de permeação a gás. ................................................ 36

Figura 11. Micrografia das secções transversais das membranas de PEI produzidas a partir de planejamento experimental.

Figura 12. Superfície de resposta da interação entre as variáveis V1(temperatura do banho de imersão)

e V2 (espessura úmida da membrana de PEI) e V3 (concentração da solução de PEI). 49

Figura 13. Representação das moléculas de DOPA e dopamina. 56

Figura 14. Representação esquemática da autopolimerização de moléculas de DOPA 56

Figura 15. Imagens digitais de membranas de PEI modificadas e não modificada 63

Figura 16. Espectro de IVTF obtido para cloreto de dopamina 64

Figura 17. Espectro IVTF obtido para membrana de PEI 66

Figura 18. Espectros obtidos para a série de membranas de PEI modificadas, para a membrana de PEI não modificada e para cloreto de dopamina. 68

Figura 19. Curvas termogravimétricas obtidas para a série de membranas de PEI modificadas e não modificada. 69

Figura 20. Curvas termogravimétricas derivadas obtidas para a série de membranas de PEI modificadas e não modificada. 70

Figura 21. Taxas de permeação de vapor de água obtidas para membranas de PEI não modificada e modificadas. 73 


\section{LISTA DE TABELAS}

Tabela 1. Descrição das variáveis e dos níveis utilizados na etapa de produção das membranas........ 30

Tabela 2. Planejamento fatorial completo em dois níveis

Tabela 3. Condições experimentais e espessura das membranas obtidas por planejamento experimental.

Tabela 4. Valores de ângulo de contato obtidos pelo método da gota séssil no modo estático. 44

Tabela 5. Planejamento experimental completo em dois níveis (valores decodificados) e resultados experimentais das análises de transporte

Tabela 6. Análise de variância para as análises de transporte: permeação ao vapor de água e aos gases $\mathrm{O} 2$ e $\mathrm{CO} 2$

Tabela 7. Valores de permeância (experimentais e de referência) para os gases $\mathrm{O} 2$ e CO2. 51

Tabela 8. Amostra produzidas por modificação bioinspirada 59

Tabela 9. Principais atribuições de bandas de absorção no IV para cloreto de dopamina 65

Tabela 10. Principais atribuições de bandas de absorção no IV obtidas para membrana de PEI 67

Tabela 11. Valores de ângulo de contato obtidos para a série de membranas de PEI modificadas e não modificada a partir de diferentes líquidos de prova.

Tabela 12. Valores de componente dispersiva $\left(\Upsilon^{\mathrm{LW}}\right)$, componente polar $\left(\Upsilon^{\mathrm{AB}}\right)$, elétron doador $\left(\Upsilon^{-}\right)$, elétron receptor $\left(\Upsilon^{+}\right)$, energia livre de superfície $\left(\Upsilon^{\text {total }}\right)$ e energia livre de interação $(\Delta \mathrm{G})$, em mJ m${ }^{-2}$ obtidos para a série de membranas de PEI modificadas e não modificada.

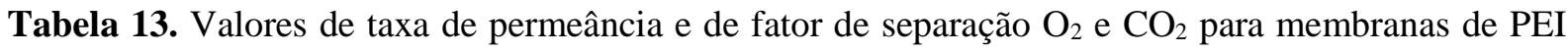
modificadas e não modificada. 


\section{Sumário}

JUSTIFICATIVA...

APRESENTAÇÃO

Capítulo I - Estudo sistemático da etapa de produção de membranas porosas assimétricas à base de PEI.

1 Introdução.

1.1 Processos de separação por membranas 15

1.1.1 Breve levantamento histórico 15

1.1.2 Tecnologia de membrana polimérica 16

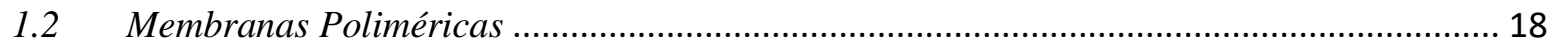

1.2.1 Membranas Poliméricas Assimétricas............................................................................. 19

1.2.2 Inversão de fases: A Técnica de Loeb-Sourirajan....................................................... 20

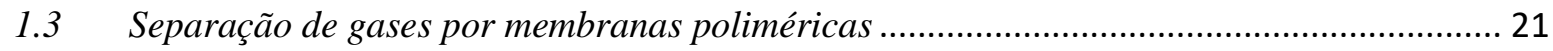

1.3.1 Mecanismos de transporte em membranas assimétricas ............................................. 23

$1.4 \quad$ Planejamento experimental e análise estatística ............................................................... 27

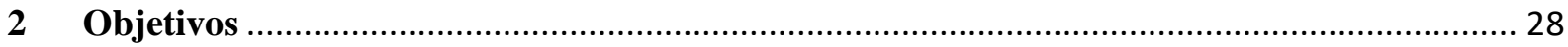

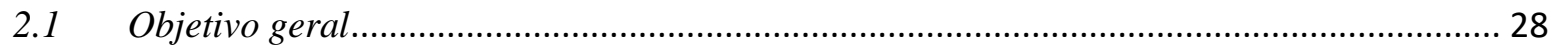

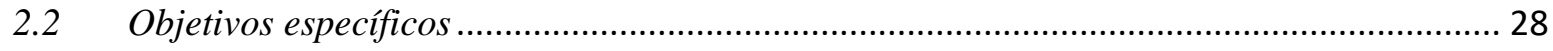

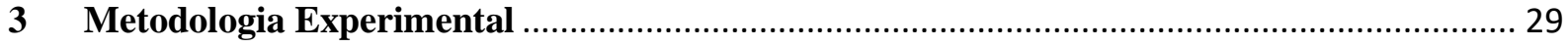

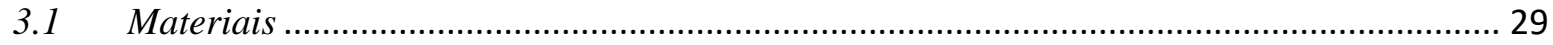

3.2 Planejamento experimental e Produção das membranas poliméricas ................................ 30

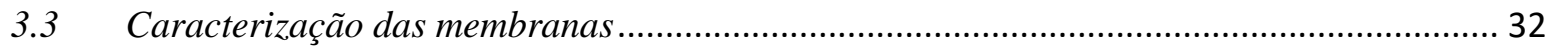

3.3.1 Microscopia Eletrônica de Varredura (MEV) ............................................................ 32

3.3.2 Ângulo de Contato ........................................................................................... 32

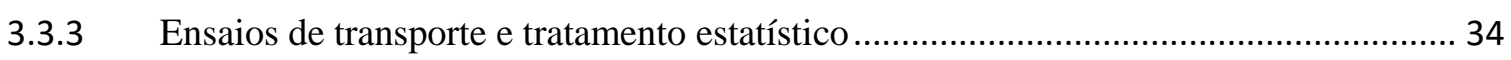

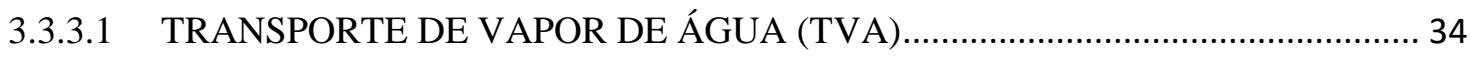

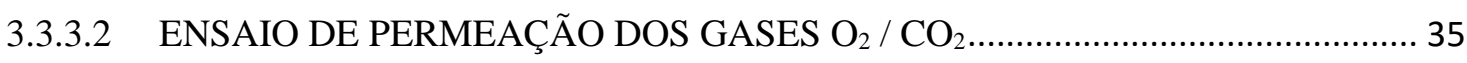

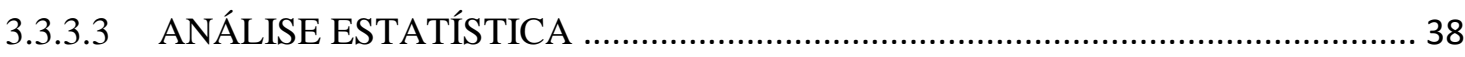

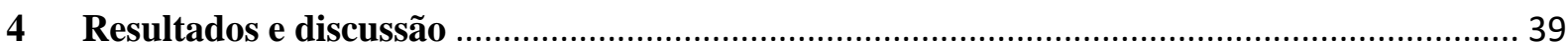

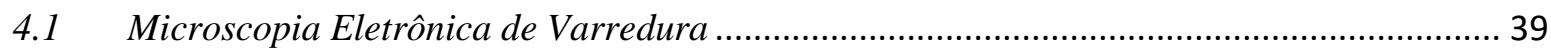

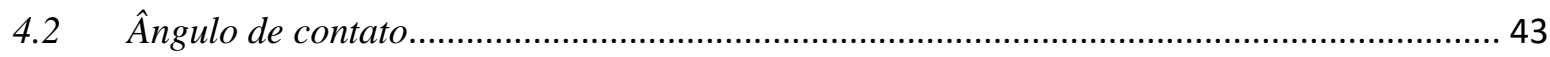

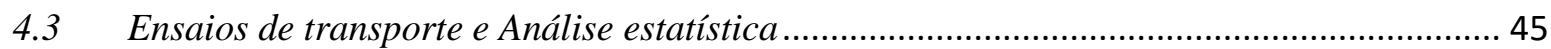

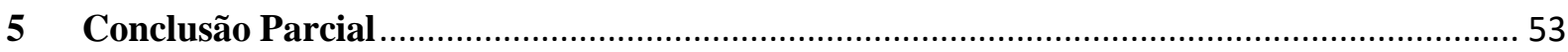

Capítulo II - Modificação superficial de membranas à base de poliéterimida. ........................... 55

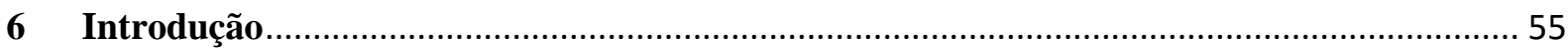

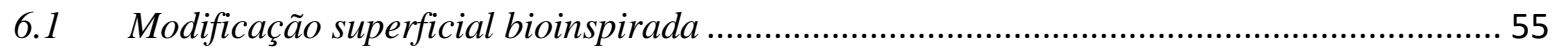




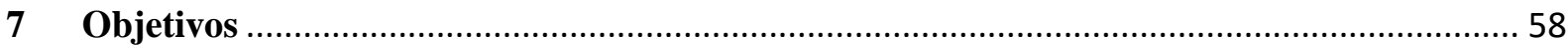

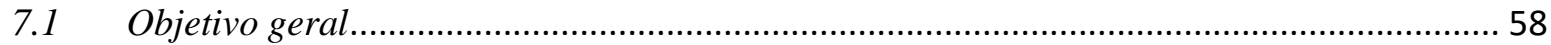

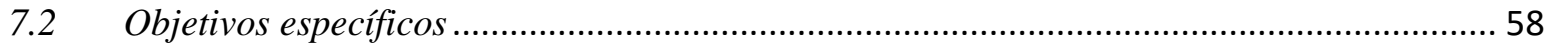

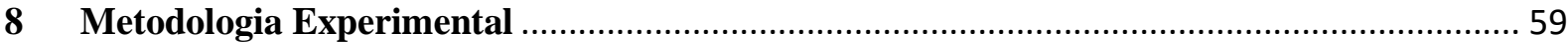

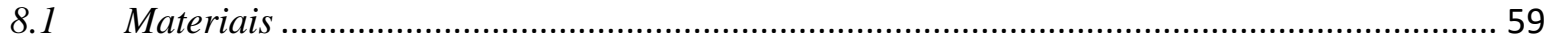

8.2 Procedimento da modificação bioinspirada ....................................................................... 59

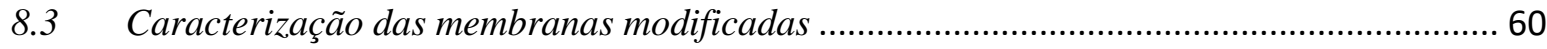

8.3.1 Espectroscopia na região do infravermelho com transformada de Fourier e acessório de

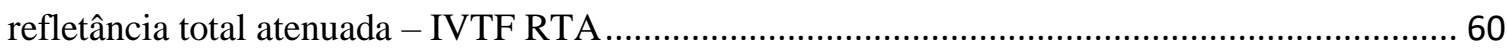

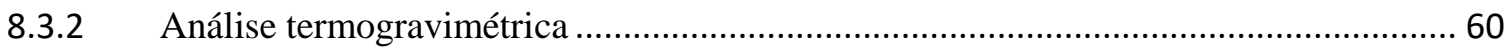

8.3.3 Medidas de ângulo de contato, energia livre de superfície e energia livre de interação $(\Delta \mathrm{G}) \quad 61$

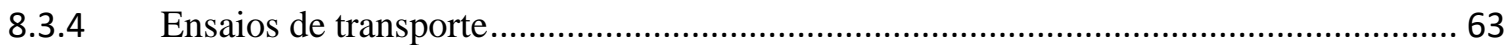

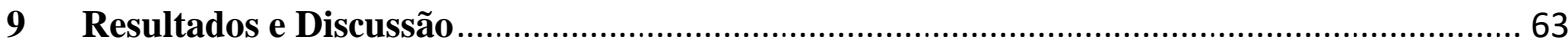

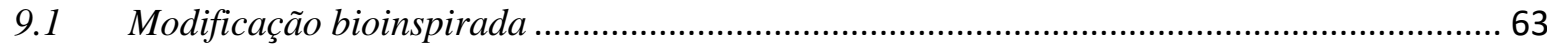

9.2 Espectroscopia na região do infravermelho com transformada de Fourier e acessório de

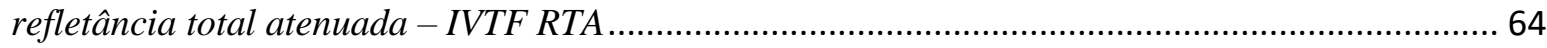

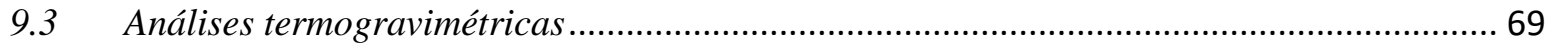

9.4 Ângulo de contato, energia de superfície e energia livre de superfície ................................ 71

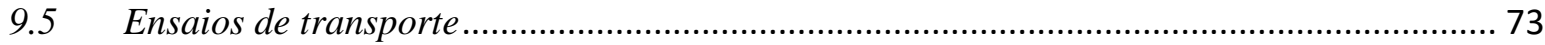

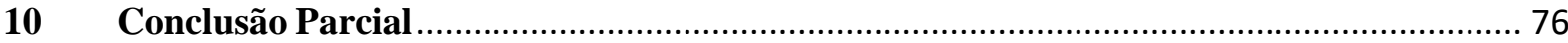

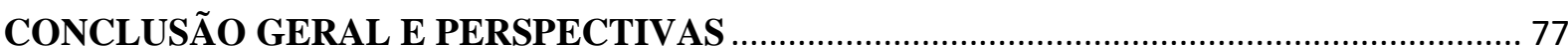

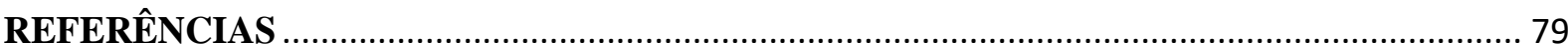




\section{JUSTIFICATIVA}

Processos de separação e extração de gases são parte importante de variados segmentos industriais, são alguns deles: extração de $\mathrm{CO}_{2}$ e $\mathrm{H}_{2} \mathrm{~S}$ de gases naturais (BAKERI; MATSUURA; ISMAIL, 2011; GEORGE et al., 2016), extração do $\mathrm{N}_{2}$ do ar, eliminação de $\mathrm{H}_{2}$ oriundos de petroquímicos (TIEN-BINH; VINH-THANG; YUAN, 2016), separação do par $\mathrm{CO}_{2} / \mathrm{CH}_{4}$ do processo de recuperação aprimorada de petróleo (SAEDI; MADAENI; SHAMSABADI, 2014).

Os processos de separação de gases foram estabelecidos no setor industrial através do emprego de técnicas, como destilação criogênica e adsorção de gás, capazes de proporcionar a obtenção de gases com alta pureza, como produto final, embora, em razão do consumo de energia, sejam considerados de alto custo (BAKERI; MATSUURA; ISMAIL, 2011; YANG et al., 2020). Neste sentido os processos de separação por membranas se apresentam vantajosos, em razão do baixo consumo de energia e, consequentemente, baixo investimento financeiro, podendo competir com processos de separação tradicionais (GEORGE et al., 2016; SAEDI et al., 2014).

A tecnologia de separação de gases por membranas tem como princípio a diferença entre as taxas de difusão dos diferentes gases, por isso utiliza menos energia, além de ser realizado em processo contínuo e sem necessidade de mudança de estado físico, diferente da maioria das técnicas tradicionais. Por isso a tecnologia de separação por membranas vem ganhando visibilidade na área da separação de gases nas últimas 3 décadas (YANG et al., 2020). As membranas poliméricas são frequentemente empregadas neste segmento, em razão de possuírem como característica estabilidade química e/ou térmica e/ou mecânica, o que os fazem materiais versáteis (GOVARDHAN; CHANDRASEKHAR; SRIDHAR, 2017; SAEDI; MADAENI; SHAMSABADI, 2014).

A performance dos processos de separação de gases é avaliada através da seletividade, que compara a permeabilidade da membrana em relação aos gases. O valor de seletividade é obtido pela relação entre as frações de cada gás, de um par, que permeia a membrana polimérica. A relação entre seletividade e permeabilidade é inversa, quanto maior a permeabilidade de um gás em uma membrana, menor a seletividade desta membrana a este gás, logo, a relação permeabilidade-seletividade pode se apresentar uma limitação desvantajosa na aplicação.

Um dos maiores desafios da tecnologia de membranas é alcançar um elevado desempenho em ambas as propriedades, permeação e seletividade, em um único material. Para 
esta finalidade, algumas técnicas já são empregadas na etapa de produção das membranas ou em posterior etapa de modificação, por exemplo: incorporação de materiais nanoestruturados (NIKPOUR; KHOSHNEVISAN, 2020; YANG et al., 2020), e incorporação de líquido iônico (LI) (TOMÉ et al., 2015; VEDOVELLO, 2017) na matriz polimérica, preparação de blendas poliméricas (SAEDI et al., 2014), inserção e modificação de camadas superficiais (CHAPMAN et al. 2008; HASHEMIFARD; ISMAIL; MATSUURA, 2011), dentre outras.

Membranas porosas assimétricas são um tipo de material que apresenta resposta permeabilidade-seletividade satisfatória a gases, como uma característica de sua estrutura microporosa na superfície e macroporosa na base (ABDUL LATIF AHMAD; OLATUNJI; JAWAD, 2017). Adicionalmente, há a possibilidade de se realizar modificações nas superfícies destes materiais que, não alteram profundamente suas estruturas, mas aprimoram propriedades de morfologia superficial, e, consequentemente, suas propriedades de transporte. Uma dessas técnicas é o recobrimento de membranas por polidopamina, conhecido como modificação bioinspirada, que tem sido empregada para aprimorar a hidrofilicidade e propriedades adesivas de variados materiais (JIANG et al., 2010; LEE, 2012; XU et al., 2018).

O emprego de membranas poliméricas na área médica representa um grande potencial de aplicação destes materiais, pois, adicionalmente ao que foi exposto anteriormente, materiais poliméricos têm sido relatados, na literatura, biocompatíveis. Um exemplo de aplicação na área médica que envolve tecnologia de membranas para permeação de gás são os processos de oxigenação sanguínea, os chamados pulmões artificiais, que são utilizados em procedimentos cirúrgicos. Estes dispositivos necessitam de materiais que fiquem em contato direto com sangue e apresentem, simultaneamente, propriedade de permear o gás $\mathrm{O}_{2}$ e ser resistente ao acúmulo de substâncias orgânicas (fouling)(BAKER, 2001a; WANG et al., 2014).

No presente trabalho, membranas assimétricas foram produzidas com o emprego da técnica de Loeb-Sourirajan, separação/inversão de fases. Para a obtenção das membranas foi empregado o polímero polieterimida (PEI), que apresenta estabilidade química e térmica (AINSCOUGH; OATLEY-RADCLIFFE; BARRON, 2017; BAKERI; MATSUURA; ISMAIL, 2011), e por ser apontado, na literatura, como uma opção satisfatória para formação de membranas assimétricas para permeação de gases (BAKERI et al., 2010; NAIM; ISMAIL, 2013). Posteriormente as membranas foram modificadas por recobrimento com polidopamina, com a finalidade de diminuir a característica hidrofóbica destes materiais e consequentemente incrementar a solubilização de espécies químicas nas suas superfícies, aprimorando suas 
propriedades de transporte e anti - fouling. Os gases empregados para avaliar a performance das membranas produzidas foram o oxigênio $\left(\mathrm{O}_{2}\right)$ e o gás carbônico $\left(\mathrm{CO}_{2}\right)$. 


\section{APRESENTAÇÃO}

O presente trabalho tratou de estudo sistemático e comparativo sobre membranas poliméricas porosas assimétricas à base de PEI, tendo sido realizado nas seguintes etapas: $a$. produção e caracterização das membranas obtidas, $b$. modificação de superfície e caracterização de membranas de PEI.

Com a intenção de organizar os assuntos, e facilitar a leitura e compreensão, esta tese encontra-se dividida em três capítulos. O primeiro capítulo contempla revisão bibliográfica sobre processos de separação e membranas poliméricas, com ênfase em membranas poliméricas porosas assimétricas, planejamento experimental e análise estatística, estudo sistemático sobre a etapa de produção de membranas poliméricas porosas assimétricas, no qual abrange planejamento experimental e metodologia, caracterizações, discussão dos resultados e análise estatística, e conclusões parciais. O segundo capítulo consiste no estudo comparativo entre membranas não modificadas e modificadas, onde a técnica de modificação bioinspirada, empregada para modificar as superfícies de membranas de PEI obtidas na primeira etapa do trabalho, é apresentada. Este capítulo abrange revisão bibliográfica sobre a técnica de modificação, metodologia experimental, caracterização e conclusões finais. 


\section{Capítulo I - Estudo sistemático da etapa de produção de membranas porosas assimétricas à base de PEI.}

\section{Introdução}

\subsection{Processos de separação por membranas}

\subsubsection{Breve levantamento histórico}

Os estudos à cerca dos fenômenos envolvendo membranas poliméricas datam do século XVIII, quando o francês Abbé Nollet, em 1748, ensaiou um experimento de permeação, usando uma membrana de origem natural, e apresentou ao mundo o fenômeno da osmose. No século XIX e início do século $\mathrm{XX}$, os processos envolvendo membranas se restringiram a procedimentos laboratoriais científicos, no sentido de compreender os fenômenos de permeação e seletividade. Esses conhecimentos foram empregados em experimentos que embasaram o desenvolvimento de teorias físicas e químicas, como a equação de van’t Hoff para soluções ideais e a teoria cinética dos gases por Maxwell.

Em 1861 Graham reportou seu primeiro experimento de diálise usando membrana sintética. Mais tarde, em 1907, membranas porosas de nitrocelulose foram criadas em laboratório, por Bechhold, e em 1930, após serem aprimoradas, estavam disponíveis comercialmente.

A tecnologia de membranas poliméricas teve sua primeira aplicação significante, ao final da $2^{\mathrm{a}}$ Guerra Mundial, em testes para obtenção de água potável. Os resultados promissores foram explorados pela Millipore Corporation, EUA, a primeira empresa produtora de membranas para microfiltração.

A tecnologia de membranas pode ser dividida em duas gerações. A primeira foi o desenvolvimento das membranas para processos de micro, ultra e hiperfiltração, osmose e diálise. A segunda geração foi a evolução das membranas para aplicação em separação de gases, destilação e pervaporação e membranas liquidas. O grande avanço na tecnologia de membranas para processos de separação foi marcado pelo desenvolvimento da membrana assimétrica por Loeb e Sourirajan, em meados dos anos 1960. Por apresentar taxa de permeação mais elevada que as membranas já empregadas para osmose reversa, até então, despertou grande interesse da indústria. A partir desse momento, inicia-se a fase de aperfeiçoamento das membranas 
poliméricas, para que mais processos industriais, como separação de gases, destilação por membranas e pervaporação, pudessem ser atendidos (BAKER, 2001).

De 1960 a 1980 o status da tecnologia de membranas poliméricas mudou significativamente, e os tipos de membranas desenvolvidas naquela época são produzidas e aprimoradas até hoje, através de estudos sobre método de produção (BAKERI et al., 2014; UENISHI et al., 2014), modificações de matriz (MAHAJAN; KOROS; THUNDYIL, 1999; ZULHAIRUN et al., 2014), entre outras técnicas.

\subsubsection{Tecnologia de membrana polimérica}

Em uma abordagem simplista, o processo de separação por membranas envolve um dispositivo que possui face de alimentação, por onde se insere a mistura, e as faces de saída, por onde o permeado e retido são recolhidos. A Figura 1 ilustra um esquema genérico de um módulo de separação por membrana.

Figura 1. Ilustração de um módulo de separação por membrana.

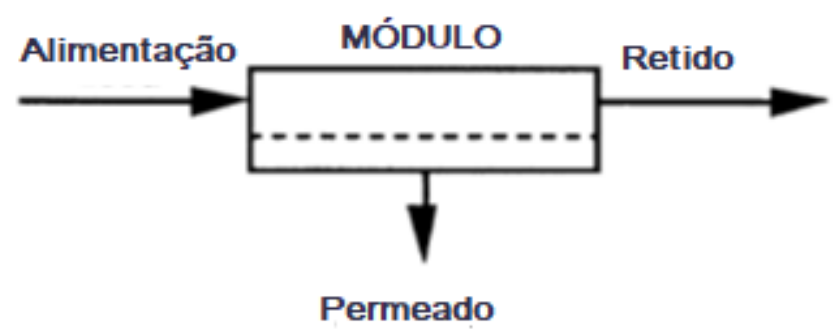

Fonte: ADAPTADO de Mulder (1992)

Dentro do dispositivo é alocada a membrana, que é a barreira permeável-seletiva, e separa a fase da mistura da fase do permeado.

A separação ocorre porque a membrana tem habilidade de permitir a permeação de alguns componentes mais eficientemente do que de outros. Esse fenômeno se dá em razão de diferenças em propriedades e/ou características entre membrana e componentes a serem permeados, como: tamanho, carga e afinidade química. 
A permeação através da membrana é possível pela existência de uma força motriz (gradiente de pressão, concentração, potencial elétrico, temperatura, etc.) que impacta individualmente os componentes da mistura, resultando na permeação diferenciada, ou, na não permeação de componente(s)(MULDER, 1992). A Figura 2 ilustra um esquema de permeação através de membrana.

Figura 2. Representação esquemática de separação por membrana.

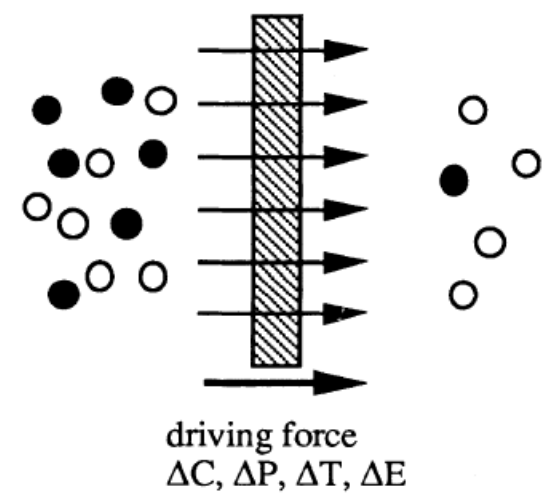

Fonte: ADAPTADO de Mulder (1992)

A taxa de permeação de um processo de separação por membrana baseia-se na condição de processo irreversível. Logo, a permeação que ocorre irreversivelmente devido a força motriz empregada estabelece uma relação descrita por uma equação fenomenológica linear (BAKER, 2001b), Equação 1.

$$
J=-A \frac{d X}{d x} \quad \text { Equação } 1
$$

onde J é o fluxo, $A$ é o coeficiente fenomenológico; $d X / d x$ é o gradiente de força motriz no eixo perpendicular à membrana.

Em resumo, um processo de separação por membranas ocorre devido a aplicação de uma força motriz que "empurra" a mistura em direção perpendicular a membrana, a barreira permeável - seletiva, responsável pela separação dos componentes. Cada tipo de processo de separação exige força motriz e membrana específicas. 
Dois parâmetros são utilizados para se avaliar a performance de um processo de separação por membranas: a taxa de permeação, e a seletividade do meio separador (MULDER, 1992). Que impactam diretamente no rendimento do processo e na pureza do produto resultante.

A taxa de permeação, ou fluxo, Equação 1, é dada pela quantidade de permeado (em volume, massa ou mol) que atravessa determinada área da membrana em uma quantidade de tempo. Quanto mais elevada a taxa de permeação, mais rápido o processo de separação.

A eficiência de separação das membranas pode ser avaliada por dois parâmetros: retenção $(\mathrm{R})$ e seletividade $(\alpha)$. A retenção, Equação 2, diz respeito a fração retida na membrana, ou seja, que não permeia, e é empregada para separações de soluções, cujo retido é composto por particulados sólidos e o permeado é líquido.

$$
R=1-\frac{C p}{C f} \quad \text { Equação } 2
$$

onde Cp é a concentração de soluto no permeado, e Cf é a concentração do soluto na alimentação.

Já a seletividade avalia a quantidade relativa de cada componente na fase do permeado em relação a fase da alimentação, Equação 3 é empregada na separação de gases e na separação de líquidos orgânicos.

$$
\alpha=\frac{Y A / Y B}{X A / X B} \quad \text { Equação } 3
$$

onde $\mathrm{Y}_{\mathrm{A}}$ e $\mathrm{Y}_{\mathrm{B}}$ são as concentrações dos componentes $\mathrm{A}$ e $\mathrm{B}$ no permeado, e $\mathrm{X}_{\mathrm{A}}$ e $\mathrm{X}_{\mathrm{B}}$ são as concentrações dos componentes A e B na alimentação.

\subsection{Membranas Poliméricas}

As membranas, de uma forma simplista, são definidas como uma barreira permeávelseletiva que separa duas fases. São classificadas de acordo com: $a$ ) origem: natural ou sintética; b) estado físico: sólida ou líquida; c) morfologia: simétrica ou assimétrica, porosa ou não porosa; $d$ ) composição: integral ou composta. Estas características não somente classificam as membranas, mas também determinam o mecanismo de transporte no processo de separação, e, 
consequentemente, suas aplicações (BAKER, 2001). Os principais tipos de membranas poliméricas estão compilados na Figura 3.

Figura 3. Principais tipos de membranas poliméricas.

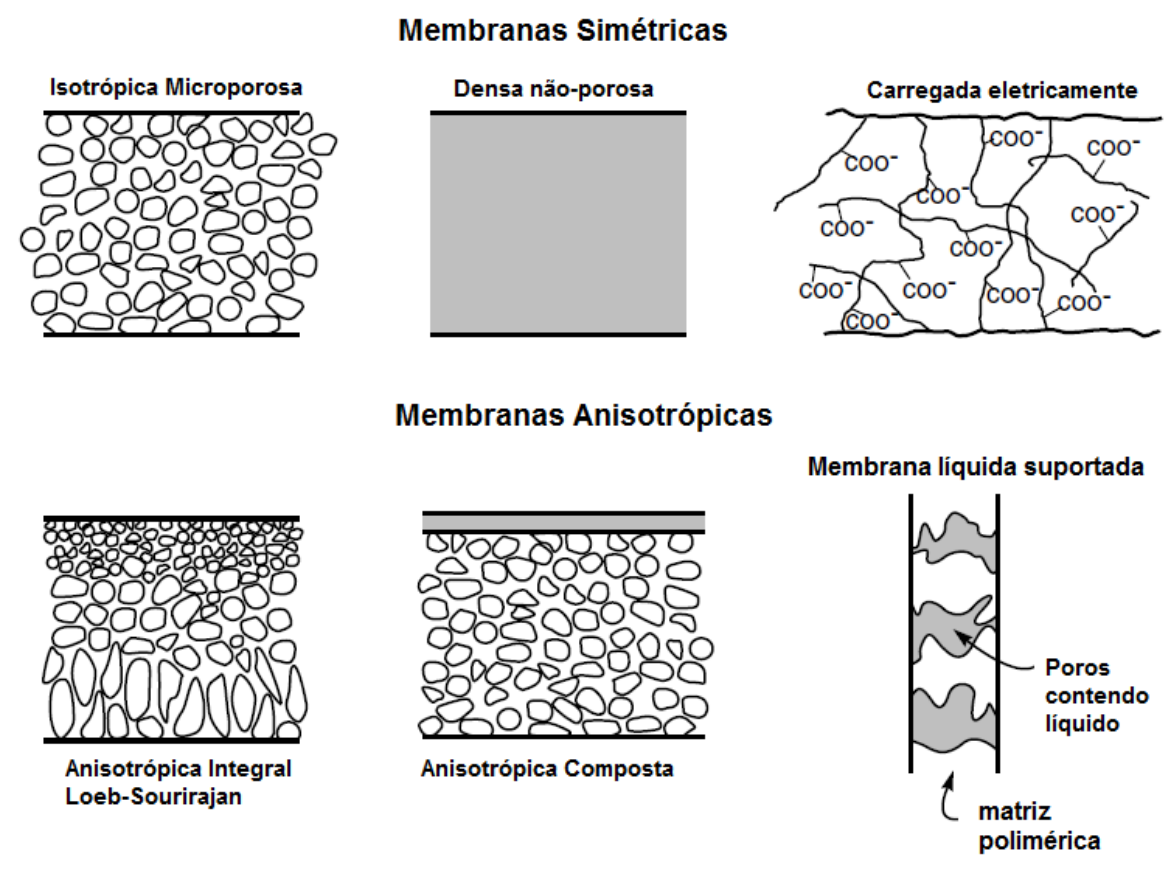

Fonte: ADAPTADO de BAKER em Vedovello (2017)

\subsubsection{Membranas Poliméricas Assimétricas}

As membranas assimétricas, ou anisotrópicas, são aquelas que possuem morfologia heterogênea em sua extensão. Elas podem ser produzidas a partir de um ou mais componentes poliméricos. Podem apresentar dois tipos de morfologia: $a$ ) com camada superficial densa e suporte macroporoso (dual layer), produzida em duas etapas; $b$ ) produzida em uma única etapa, resulta em membrana com base macroporosa e camada superficial fina com ou sem a presença de microporos e/ou defeitos. A morfologia das membranas assimétricas é resultante do método de produção.

As membranas assimétricas produzidas em uma única etapa, são obtidas principalmente, pela técnica de separação de fases, ou inversão de fases, denominação mais comum. Essa técnica foi desenvolvida, entre 1958 e 1960, por Sidney Loeb e Srinivasa Sourirajan, a partir da imersão de uma solução de acetato de celulose em banho de água, induzindo a precipitação do 
polímero. O resultado obtido foi uma membrana assimétrica, composta por uma fina camada na superfície e base porosa heterogênea, que apresentou alta permeabilidade e revolucionou o processo de osmose reversa (REUVERS, 1956).

\subsubsection{Inversão de fases: A Técnica de Loeb-Sourirajan}

O processo de separação de fases, mais conhecido como inversão de fases, tem como princípio básico a perturbação de um sistema termodinamicamente estável. A técnica de precipitação por imersão consiste em um sistema ternário composto por líquidos miscíveis.

De acordo com esta técnica, a solução polimérica, fase termodinamicamente estável, é depositada em um suporte, geralmente uma placa, que na sequência é imersa em água (nãosolvente), e inicia-se o processo de deslocamento de líquidos que resulta na desestabilização do sistema. Ao longo dos anos muitas aproximações foram pensadas a fim de esquematizar o processo da separação de fases de Loeb-Sourirajan, muitas delas se baseiam em diagrama de fases ternário, como o da Figura 4.

Figura 4. Digrama de fases ternário da obtenção de membranas pelo método da separação de fases por precipitação.

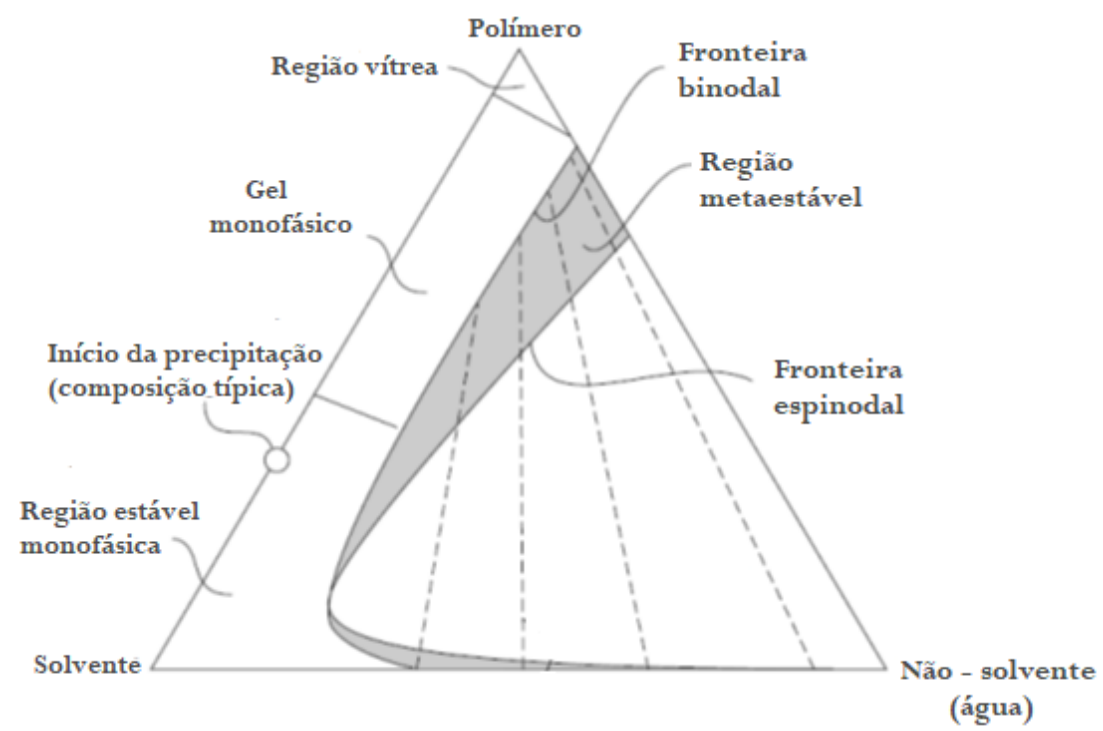

Fonte: ADAPTADO de Baker (2001) 
No diagrama de fases observa-se que a partir de uma certa quantidade de não-solvente adentrando a solução polimérica, o sistema passa da condição de uma única e estável fase para a condição de fase instável. À medida que a solução polimérica vai perdendo solvente, e ganhando água, passam a coexistir as fases: rica, com maior concentração polimérica; e pobre, com baixa concentração polimérica misturada a água e solvente. Ao longo do eixo solventepolímero, pode-se observar a variação da composição da solução polimérica, devido à perda de solvente. A partir de um ponto crítico de concentração, a solução se encontra em condição de iniciar o processo de solidificação da solução polimérica, decorrente da alta viscosidade, que impede o movimento das cadeias poliméricas, fixando a matriz final. A fase pobre, dispersa na matriz formada pela fase rica, dá origem aos microporos, e a coalescência desses, dá origem aos macroporos. Por observação experimental é possível identificar o início da precipitação pela opacidade que é adquirida pela membrana na etapa da imersão. Após toda a membrana se tornar opaca, ocorre seu descolamento da placa suporte, indicando que a matriz polimérica sólida foi obtida (BAKER, 2001b; VAN DE WITTE et al., 1996).

Há de se considerar que a taxa e a rota de precipitação diferem em variadas partes da solução polimérica. Assim que a solução polimérica é imersa em banho de não-solvente, sua superfície é primeiramente induzida à precipitação, formando rapidamente uma fina camada de estrutura microporosa. Esta face que se forma se comporta como uma barreira, que provoca atraso na perda de solvente e na entrada de água, resultando em lenta precipitação no sentido topo-base, e resultando em formação de matriz macroporosa (WIENK et al., 1996).

De acordo com tal consideração, ficou entendido que os sistemas ternários de precipitação, compostos por polímero, solvente e não-solvente, não são simplistas, pois dependem da abordagem cinética e termodinâmica, relacionada à composição destes. Outrossim, depende de variáveis controladas, como temperatura e concentração inicial da mistura solvente-polímero, e a combinação exclusiva de fatores pode resultar em variadas morfologias.

\subsection{Separação de gases por membranas poliméricas}

Os estudos sobre permeação de gases por membranas foram iniciados por Thomas Graham, em 1850. Seus estudos sistemáticos consistiram em sintetizar gases, e testá-los em diversos diafragmas, os disponíveis na época, a fim de conhecer a taxa de permeação. Graham 
contribuiu significativamente com a elucidação dos mecanismos de permeação de gases através de membranas, descrevendo o modelo da sorção-difusão para membranas densas, e a lei de difusão de Graham para membranas porosas. Durante a década de 1940 a 1950, Barrer, van Amerongen, Stern, Meares entre outros, lançaram as bases da teoria moderna para permeação de gases. O desenvolvimento de membranas poliméricas assimétricas de alto fluxo e dos módulos de membranas de grande área superficial para aplicações em osmose reversa, no início de 1970, forneceu a base de conhecimento para alavancar a tecnologia de separação de gases por membranas poliméricas. A partir de então a aplicação comercial da tecnologia de membranas em processos de separação de gases teve início (BAKER, 2001b; MULDER, 1992).

Os processos de separação de gases (incluindo os industriais) por membranas densas já são bem estabelecidos, pelo fato de que o mecanismo de transporte por essas membranas, modelo da sorção-difusão, ser consolidado e abrangente (RANGARAJAN et al., 2002).

Membranas porosas também são empregadas como barreiras seletivas em processos de separação de gases. Contudo não há um único mecanismo de transporte que rege esses processos. De acordo com a morfologia da membrana porosa, em relação ao tamanho médio dos poros, um mecanismo específico será responsável pela permeação das moléculas de gases através da membrana.

A análise teórica da permeação de gás por membranas microporosas depende da relação entre a mobilidade das moléculas (caminho livre) e o tamanho médio dos poros, pois desta relação depende o transporte das moléculas através dos poros das membranas, que pode ocorrer com choques predominantes entre moléculas e paredes dos poros ou choques predominantes entre moléculas. Assim para membranas que apresentam o tamanho de poro muito maior que o caminho livre das moléculas, o mecanismo de transporte característico é descrito pelo fluxo de Poiseuille (convectivo), já o transporte de gases em membranas que apresentam o tamanho de poro muito menor que o caminho livre das moléculas é descrito pela difusão de Knudsen. Em membranas com poros muito menores, da ordem de $5-20 \AA$, a separação ocorre por peneiramento molecular (HASHEMIFARD; ISMAIL; MATSUURA, 2013), Figura 5. 
Figura 5. Representação dos mecanismos de permeação por membranas porosas.

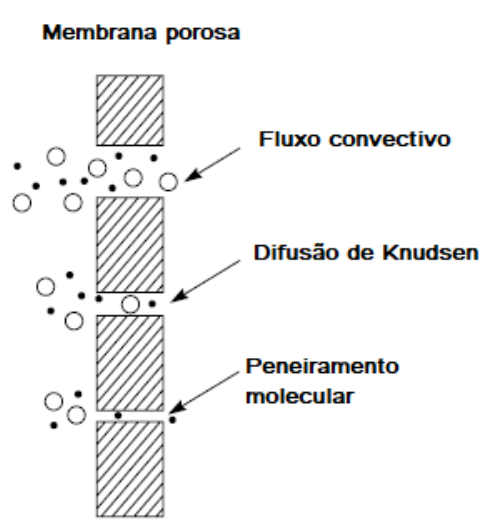

Fonte: ADAPTADO de Baker (2001)

Em grande parte dos processos de transporte de massa, inclusive nos naturais, a transferência de componentes através de barreiras físicas permeáveis ocorre por difusão e convecção. O fenômeno da difusão é um processo de transferência de massa em razão da existência de um gradiente de concentração. O comportamento espontâneo de migração de componentes do local mais concentrado para o menos concentrado foi reconhecido por Fick, que formulou a $1^{\mathrm{a}}$ lei de Difusividade (BAKER, 2001b), Equação 4:

$$
J i=-D i \frac{d C i}{d x} \quad \text { Equação } 4
$$

onde $D i$ é o coeficiente de difusividade; $d C i / d x$ é o gradiente de concentração no eixo x.

\subsubsection{Mecanismos de transporte em membranas assimétricas}

As membranas assimétricas integrais possuem duas características importantes que influenciam suas propriedades de permeação e seletividade no emprego em processos de separação de gases: os poros e/ou defeitos superficiais, e a fina espessura da camada superficial.

Em termos de difusão, a taxa de permeação de componentes através de uma membrana é inversamente proporcional a sua espessura, assim membranas assimétricas apresentam mais alta taxa de permeação em comparação às porosas simétricas, em razão de o transporte ser controlado pela camada superficial extremamente fina. 
Para que a membrana assimétrica apresente permeação satisfatória é necessário que a base macroporosa da membrana seja formada por poros abertos e abundantes, para que não haja resistência ao fluxo das moléculas de gás capazes de permear a camada superficial. A contribuição do fluxo de moléculas pela camada macroporosa, na taxa de permeação total, é negligenciável.

Uma abordagem teórica de permeação de gás por estruturas microporosas (assumidas como capilares tubulares com distribuição normal de tamanho de poros) considera a existência de mais de um mecanismo de transporte. Mecanismos estes que consideram a comparação entre diâmetro médio dos poros $\left(r_{p}\right)$ e caminho livre das moléculas $(\lambda)$ (relacionado à mobilidade das moléculas). Para um dado gás, em condições conhecidas $(\mathrm{T}, \Delta \mathrm{P}, \sigma)$ o $\lambda$ pode ser calculado pela Equação 5:

$$
\lambda=\frac{K_{B} T}{2^{1 / 2} \pi \sigma^{2} P} \quad \text { Equação } 5
$$

onde $K_{B}=$ constante de Boltzmann, $T=$ temperatura absoluta, $\sigma=$ diâmetro de colisão, $P=$ pressão do sistema.

O número de Knudsen, Equação 6, relaciona a mobilidade das moléculas permeantes e o diâmetro médio dos poros:

$$
K n=\frac{\lambda}{2 r_{p}} \quad \text { Equação } 6
$$

onde $r_{p}=$ diâmetro médio do poro.

Quando o Kn é $\geq 10$, de acordo com a Equação 6, o $\lambda$ é maior que o diâmetro do poro, a mobilidade das moléculas é grande e os choques entre moléculas e parede dos poros é predominante durante a permeação. Nas regiões com estas características, denominada região molecular livre, o mecanismo de transporte predominante é a difusão de Knudsen, Equação 7: 


$$
J_{K}=\frac{2 r_{p} A_{p}}{3 R T}\left(\frac{8 R T}{\pi M}\right)^{1 / 2} \frac{\Delta P}{l_{p}} \quad \text { Equação } 7
$$

onde $r_{p}=$ diâmetro do poro, $A_{p}=$ área do poro, $l_{p}=$ comprimento do poro, $T=$ temperatura absoluta, $\Delta P$ = variação de pressão do sistema, $R=$ constante dos gases, $M=$ massa molar do gás.

Quando o $K n$ é $\leq$ 0,001(de acordo com a Equação 6), o $\lambda$ é muito pequeno, há pouca mobilidade das moléculas, o $\lambda$ é menor que o diâmetro do poro. Como consequência, os choques predominantes nestas regiões, ocorrem entre moléculas. Nas regiões com estas características, denominada região contínua, o mecanismo de transporte predominante, no caso de substâncias puras, é o fluxo viscoso, regido pelo modelo matemático de Hagen-Poiseuille, Equação 8;

$$
J_{v}=\frac{r_{p}{ }^{2} A_{p} P}{8 \mu R T} \frac{\Delta P}{l_{p}} \quad \text { Equação } 8
$$

onde $r_{p}=$ diâmetro do poro, $A_{p}=$ área do poro, $l_{p}=$ comprimento do poro, $T=$ temperatura absoluta, $\Delta P=$ variação de pressão do sistema, $R=$ constante dos gases, $\mu=$ viscosidade do gás, $P=$ expansão do gás durante permeação.

Quando se analisa o transporte de massa em regiões contínuas de permeação para misturas, o mecanismo de transporte responsável pela permeação é a difusão molecular. Contudo, pode haver regiões com características intermediárias em processos de permeação de gases. E, nestes casos, haverá contribuições de mais de um mecanismo de transporte.

Tratam-se de regiões de transição, quando o valor $K n$ se encontra na faixa $0,1 \leq K n \leq$ $10 ; \lambda$ e $r_{p}$ são comparáveis, e podem coexistir choques tanto entre moléculas, quanto entre molécula e parede de poro, e haverá contribuição tanto de fluxo viscoso de Poiseuille, Equação 8, quanto de difusão de Knudsen, Equação 7. 
Uma terceira contribuição ainda pode ocorrer, em casos em que $0,001 \leq K n \leq 0,1$, região de muito baixa mobilidade molecular, o transporte de moléculas ocorre por um fenômeno chamado de deslizamento, Equação 9, descrito por L. B. Loeb. Neste mecanismo as moléculas escorregam pelas paredes dos poros sob um gradiente de pressão caracteristicamente baixo.

$$
J_{s}=\frac{r_{p} A_{p}}{R T}\left(\frac{\pi R T}{8 M}\right)^{1 / 2} \frac{\Delta P}{l_{p}} \quad \text { Equação } 9
$$

onde $r_{p}=$ diâmetro do poro, $A_{p}=$ área do poro, $l_{p}=$ comprimento do poro, $T=$ temperatura absoluta, $\Delta P=$ variação de pressão do sistema, $R=$ constante dos gases, $M=$ massa molar do gás.

Para gases condensáveis, e em condições suficientes, o mecanismo de deslizamento ocorre com a adsorção de moléculas nas paredes dos poros, e a permeação ocorre através desta fase condensada, chamada de difusão superficial.

A extensão em que cada tipo de mecanismo influencia a taxa de permeação total depende das características do processo e do sistema. Em casos onde a faixa de pressão empregada abrange o regime de transição, por exemplo, os três mecanismos devem ser considerados. Em outros casos apenas o mecanismo difusivo-convectivo deve ser considerado (HASHEMIFARD; ISMAIL; MATSUURA, 2013; RANGARAJAN et al., 1984; SCHOFIELD; FANE; FELL, 1990).

Com intensão de descrever mais amplamente o fenômeno da permeação de gases por membranas microporosas assimétricas, combinações das contribuições de cada mecanismo são feitas mediante ajustes e formalismos matemático (HASHEMIFARD; ISMAIL; MATSUURA, 2013). O emprego destas equações requer informações específicas sobre as membranas, propriedades como a porosidade superficial e diâmetro médio de poro. O que, eventualmente, pode dificultar sua aplicação. 


\subsection{Planejamento experimental e análise estatística}

Os planejamentos experimentais baseados em princípios estatísticos auxiliam na extração do máximo de informações úteis sobre o sistema em estudo através da realização do mínimo número de experimentos. Esses métodos podem ser utilizados para melhorar ou otimizar processos ou produtos, permitindo produzir produtos com melhores características, reduzir tempo e custos da produção, por exemplo. (DE BARROS NETO; SCARMINIO; BRUNS, 2001; PEREIRA FILHO, 2015)

O planejamento fatorial é uma dessas ferramentas, e é uma das primeiras etapas que deve ser realizada, pois permite: identificar dentre o número de variáveis iniciais qual(ais) apresenta(m) maior importância, através do planejamento fatorial fracionário ou avaliar os efeitos das variáveis de interesse sobre a resposta em questão, através do planejamento fatorial completo. (DE BARROS NETO; SCARMINIO; BRUNS, 2001; PEREIRA FILHO, 2015)

A forma mais simples de se realizar um planejamento fatorial é identificar os fatores $(\mathrm{F})$ a serem estudados, e decidir em quantos níveis $(\mathrm{N})$ eles serão estudados, e a partir disto, aplicar a regra $\mathrm{N}^{\mathrm{F}}$ = número de experimentos a serem realizados. Cada um destes experimentos corresponde a uma combinação única dos fatores, que produzirá uma ou mais respostas.

A partir do emprego do planejamento fatorial é possível observar interações sinergéticas ou antagônicas entre as variáveis; prever a resposta do sistema em estudo em uma condição que não foi testada na prática; conhecer antecipadamente quantos experimentos deverão ser realizados para alcançar determinado objetivo; e gerar menos resíduos químicos (talvez matemáticos também), o que contribui para os princípios de química verde e economia de tempo. (PEREIRA FILHO, 2015)

A análise estatística visa a obtenção de modelos matemáticos mais sofisticados e compreensão mais detalhada sobre o sistema estudado (DE BARROS NETO; SCARMINIO; BRUNS, 2001; PEREIRA FILHO, 2015). O método da modelagem pelos mínimos quadrados, cuja significância estatística é avaliada pela análise de variância (ANOVA), e o método das superfícies de resposta (gráficos com três dimensões para apresentação dos resultados) foram empregados neste trabalho. 


\section{Objetivos}

\subsection{Objetivo geral}

Realizar estudo sistemático da etapa de produção de membranas porosas assimétricas à base de polieterimida, com o objetivo de investigar, através de planejamento experimental e análise estatística, a melhor condição experimental de obtenção de materiais que apresentem altas taxas de permeação ao vapor de água, e seletividade ao par gasoso $\mathrm{O}_{2} / \mathrm{CO}_{2}$.,

\subsection{Objetivos específicos}

- Produzir membranas microporosas assimétricas à base de polieterimida através do emprego da técnica de inversão de fases (Loeb-Sourirajan) e caracterizá-las em relação a propriedades morfológicas e propriedades de transporte;

- Através de planejamento fatorial completo identificar a influência dos fatores: $a$. temperatura do banho, $b$. espessura úmida da membrana e $c$. concentração da solução polimérica, na etapa de produção das membranas;

- Analisar, comparativamente, as morfologias das membranas obtidas, através das técnicas de micrografia eletrônica de varredura e ângulo de contato;

- Analisar, através do emprego de análise estatística, as propriedades de transporte das membranas obtidas, a partir de ensaios de permeação de vapor de água, permeação dos gases $\mathrm{O}_{2}$ e $\mathrm{CO}_{2}$, e determinação da seletividade $\mathrm{O}_{2} / \mathrm{CO}_{2}$.

- A partir do conjunto total de dados obtidos na etapa de caracterização identificar a melhor condição experimental para a obtenção de membranas altamente permeáveis e seletivas a gases e vapores 


\section{Metodologia Experimental}

\subsection{Materiais}

$\mathrm{Na}$ etapa de produção das membranas poliméricas foram empregados os seguintes materiais:

- ULTEM $^{\mathrm{TM}} 1010$

Resina de polieterimida (PEI), um termoplástico de engenharia, que foi criada e introduzida no mercado pela divisão de polímeros da General Electric GE, na década 1950 60. A Sabic Innovative Plastics (Sabic IP) é uma das atuais fabricantes da resina ULTEM. No portfólio da supracitada fabricante a resina é disponibilizada em diversas formulações, compostas apenas por PEI (série ULTEM ${ }^{\mathrm{TM}} 1010$ ) ou combinada com outros materiais (série ULTEM $^{\mathrm{TM}}$ 2100, composta por PEI e fibra de vidro). (RESINEX, [s.d.]; SABIC, [s.d.])

Neste trabalho a resina ULTEM $^{\mathrm{TM}} 1010$ foi o material empregado para produzir as membranas objeto de estudo. A temperatura de transição vítrea do PEI-ULTEM ${ }^{\mathrm{TM}} 1010$ se apresenta em torno de $217^{\circ} \mathrm{C}$ e sua massa molar ponderal média (Mw) é de aproximadamente $48.000 \mathrm{~g} \cdot \mathrm{mol}^{-1}$ (SABIC, 2017).

O PEI, Figura 6, é um polímero que apresenta unidades repetitivas unidas por ligações éter e imida. Devido à estabilidade da ligação imida é conferida à cadeia polimérica rigidez e alta resistência ao calor. Enquanto que as ligações éter entre os anéis fenílicos proporcionam flexibilidade na cadeia, permitindo o processamento do polímero e boas características de fluxo (SMITH E HASHIMED, 2009).

Figura 6. Representação da unidade monomérica de repetição do PEI.<smiles>Cc1cccc(N2C(=O)c3ccc(Oc4ccc(C(C)(C)c5ccc(Oc6ccc7c(c6)C(=O)N(C)C7=O)cc5)cc4)cc3C2=O)c1</smiles>

Fonte: Adaptado de SMITH E HASHIMED (2009). 
Este material é frequentemente empregado na produção de membranas em razão de possuir estabilidade química e térmica. Especificamente em estudos sobre permeação de gases, membranas densas de PEI se mostraram seletivas para importantes pares gasosos, assim como em estudos sobre separação de gases, o PEI tem se mostrado eficaz na formação de membranas porosas assimétricas, método da inversão de fases. (WANG,1998; AHMAD 2013, 2017)

- N-Metil Pirrolidona

Também conhecido comercialmente com o nome pharmasolve ${ }^{T M}$, é utilizado como solvente em diversos processos envolvendo hidrocarbonetos, polímeros, têxteis e fármacos. É um solvente polar aprótico, miscível em água e em outros solventes, como: dimetilformamida, acetato de etila, álcoois e cetona de cadeias carbônicas pequenas. Possui baixa volatilidade, ponto de fusão $-24{ }^{\circ} \mathrm{C}$ e ponto de ebulição $202{ }^{\circ} \mathrm{C}$, e é quimicamente estável em temperatura ambiente (ASHLAND; MULTI CHEMIE, 2011)

\subsection{Planejamento experimental e Produção das membranas poliméricas}

A primeira parte da etapa de produção das membranas foi a realização de um planejamento experimental. Com base em levantamento bibliográfico foram estipuladas as variáveis investigadas assim como os níveis empregados no estudo, Tabela 1, que resultou em um planejamento fatorial completo em dois níveis $\left(2^{3}\right)$, ou seja, oito experimentos fatoriais ortogonais, Tabela 2.

Tabela 1. Descrição das variáveis e dos níveis utilizados na etapa de produção das membranas.

\begin{tabular}{lll}
\hline \hline Variáveis & Nível (-) & Nível (+) \\
\hline \hline 1. Temperatura do banho & $25^{\circ} \mathrm{C}$ & $65{ }^{\circ} \mathrm{C}$ \\
2. Espessura da membrana & $100 \mu \mathrm{m}$ & $300 \mu \mathrm{m}$ \\
3. Conc. Sol. Polimérica $(m / m)$ & $25 \% \mathrm{PEI} / 75 \% \mathrm{NMP}$ & $35 \% \mathrm{PEI} / 65 \% \mathrm{NMP}$ \\
\hline \hline
\end{tabular}


Tabela 2. Planejamento fatorial completo em dois níveis.

\begin{tabular}{cccc}
\hline \hline Membranas & Variável 1 & Variável 2 & Variável 3 \\
\hline \hline PEI 1 & - & - & - \\
PEI 2 & + & - & - \\
PEI 3 & - & + & - \\
PEI 4 & + & + & - \\
PEI 5 & - & - & + \\
PEI 6 & + & - & + \\
PEI 7 & - & + & + \\
PEI 8 & + & + & + \\
\hline \hline
\end{tabular}

O método empregado para a produção das membranas foi o de inversão de fases, que consiste em um sistema ternário formado por solução polimérica (sistema binário homogêneo) e um não solvente ao polímero, para compor o banho de coagulação, anteriormente explicado (seção 1.3).

As soluções poliméricas foram preparadas de acordo com as concentrações prédeterminadas no planejamento fatorial, Tabela 1, a partir da mistura e homogeneização (agitação magnética) do PEI e do NMP, por 24 horas. Para as soluções de maior concentração foi utilizado aquecimento (máx. $80^{\circ} \mathrm{C}$ ) a fim de auxiliar na solubilização do polímero. Após esta etapa, as soluções foram deixadas em repouso por $24 \mathrm{~h}$ para que bolhas de ar, decorrentes da agitação, pudessem ser eliminadas.

A solução de PEI foi depositada, sobre placas de vidro, previamente higienizadas com acetona P.A. Nesta etapa um extensômetro multi-espessuras de aço inox (construído na Oficina Mecânica do DQ-UFSCar) foi empregado para espalhar a solução. Na sequência, as placas com as soluções poliméricas foram mergulhadas em banho de água destilada. Todo este procedimento foi realizado de acordo com as variáveis e os níveis delineados no planejamento experimental. A etapa de banho de coagulação tem duração específica par cada sistema, é possível identificar a finalização da formação da membrana quando ocorre o descolamento entre membrana e placa. Para estabelecer um protocolo para este trabalho, todas as membranas produzidas foram deixadas por30 minutos no banho de coagulação. Na sequência, as membranas permaneceram mergulhadas em um recipiente com água destilada por mais 24 
horas, para retirada do solvente remanescente. Após esse período, as membranas foram envoltas em papel absorvente, para secarem em temperatura ambiente por $48 \mathrm{~h}$.

\subsection{Caracterização das membranas}

\subsubsection{Microscopia Eletrônica de Varredura (MEV)}

A microscopia eletrônica de varredura foi a técnica empregada para avaliar a morfologia das membranas de PEI, obtidas através do planejamento experimental, por meio da captura de micrografias de faces transversais das amostras.

O preparo pré-análise consistiu no congelamento de pedaços das membranas em nitrogênio líquido, e imediata fratura. Na sequência foi feita a imobilização das amostras fraturadas em suporte metálico, do próprio equipamento, e recobrimento deste conjunto com fina $(\approx 30 \mathrm{~nm})$ camada de ouro. O equipamento utilizado para a captura das imagens foi um microscópio eletrônico de varredura digital marca LEO, modelo 440, nas condições de corrente e potência de feixe de elétrons de $0,75 \mathrm{~mA}$ e $15 \mathrm{kV}$, respectivamente, e detector de elétrons secundário (S1).

\subsection{2 Ângulo de Contato}

Uma das formas de se estimar o ângulo de contato entre uma superfície sólida e um líquido é através da medida do ângulo tangente entre uma gota líquida que é depositada em uma face sólida. Este ângulo é resultado de equilíbrio mecânico da gota sob ação de três tensões superficiais, tensão entre vapor e líquido $\left(\gamma_{\mathrm{lv}}\right)$, a tensão entre vapor e sólido $\left(\gamma_{\mathrm{sv}}\right)$ e tensão entre sólido e líquido $\left(\gamma_{\mathrm{sl}}\right)$, Figura 7. 
Figura 7. Esquema do equilíbrio mecânico entre uma gota em um sólido sob ação das tensões superficiais.

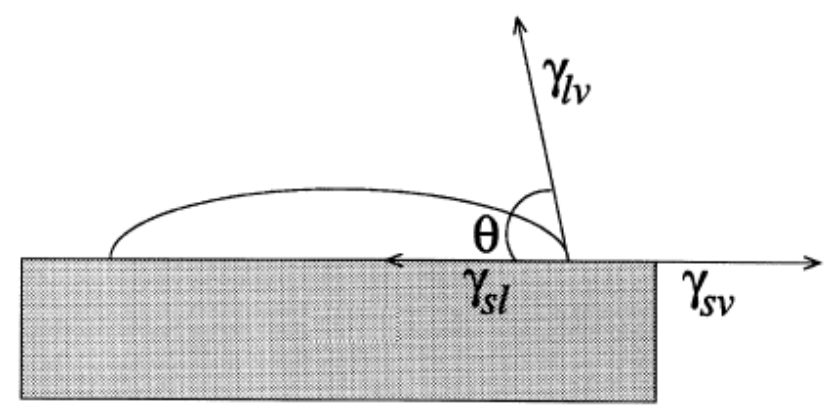

Fonte: Kwok e Neumann (1999)

Em uma situação ideal em que a superfície sólida é plana, rígida, lisa e sem deformidades, e não exista interações ou reações químicas entre sólido - líquido - vapor, seria possível medir um único ângulo de contato para a linha tangencial sólido-líquido. Nas situações reais, em que os experimentos são realizados, essas condições não são, na totalidade, obedecidas, levando a medidas de diferentes ângulos de contato em diferentes pontos da linha tangencial sólido-líquido, o que é chamado de histerese. Fica possível entender, então, que o valor medido experimentalmente para o ângulo de contato é resultado da linha tangencial sólido-líquido que se estabelece decorrente tanto das propriedades do sólido e do líquido, como hidrofilicidade/hidrofobicidade, reatividade, quanto também das características topográficas da superfície sólida, como rugosidade e deformidades (KWOK et al., 1997; YILDIRIM ERBIL et al., 1999).

Medidas do ângulo de contato entre as membranas de PEI e água destilada foram obtidas a fim de se comprovar o caráter hidrofóbico das membranas obtidas por planejamento experimental.

Tiras retangulares (aproximadamente $5 \mathrm{~cm}$ x $1 \mathrm{~cm}$ ) das membranas de PEI foram fixadas no porta-amostra do equipamento. Na sequência, com o auxílio de uma microsseringa, gotas de água destilada (aproximadamente $2 \mu$ litros) foram depositadas sobre as amostras. A análise foi executada em modo estático, ou seja, a amostra permaneceu fixa, e a cada gota depositada, os ângulos de contato foram medidos em um espaço de tempo de 60 segundos. O equipamento utilizado foi um goniômetro da marca Ramé-Hart modelo 260, que mediu e registrou, em triplicata, os ângulos de contato de ambos os lados de cada gota. Foram realizadas medidas de 3 gotas depositadas em diferentes pontos para cada tira de amostra. Assim, os valores finais de ângulo de contato correspondem à média das determinações. Esta caracterização foi realizada 
conforme protocolo ASTM D5725 (ASTM - American Society for Testing and Materials, 1999).

\subsubsection{Ensaios de transporte e tratamento estatístico}

\subsubsection{TRANSPORTE DE VAPOR DE ÁGUA (TVA)}

Esta técnica foi empregada com a finalidade de avaliar, comparativamente, a taxa de permeação do vapor de água entre as membranas de PEI.

As amostras foram recortadas na forma de discos e fixadas em copos de Payne, de acordo com o ilustrado na Figura 8. Os copos foram preenchidos com água destilada em 3/4 do seu volume, em seguida, foram aferidas suas massas em balança analítica. Em um dessecador, contendo sílica gel (atividade da água, $\mathrm{a}_{\mathrm{w}}=0,18$ ), os copos foram alocados. Esse sistema foi mantido em banho térmico a $30{ }^{\circ} \mathrm{C}$ por 10 dias, período em que as massas dos copos de Payne foram aferidas duas vezes ao dia, em concordância com protocolo ASTM E 96 (ASTM American Society for Testing and Materials, 1953).

Figura 8. Copo de Payne utilizado no ensaio de permeação ao vapor d’água.

E. Anéis de borracha

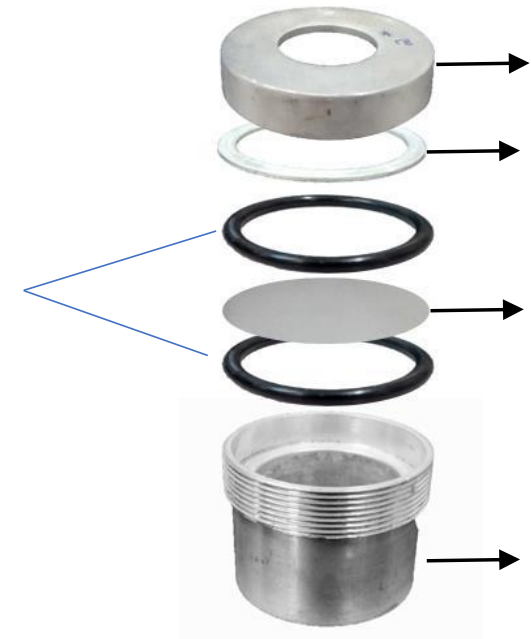

A. Tampa*

B. Anel metálico

C. Amostra

D. Copo

*Sendo (A) tampa com rosca para fechamento do copo; (B) anel metálico; auxiliar de vedação; (D) corpo do copo com espaço interno para acomodação do líquido; logo acima, espaço para fixação da amostra; (E) anéis de borracha que auxiliam a fixação da membrana e vedação do sistema.

Fonte: Vedovello (2017) 
A variação de massa entre as pesagens é decorrente do transporte de água na forma de vapor através da membrana. A relação entre a perda de massa $(\Delta \mathrm{m})$ e a variação do tempo $(\Delta \mathrm{t})$, que é linear, e a área (A) da membrana empregada na análise possibilita calcular o valor do fluxo de vapor de água $(\mathrm{J})$ transportado no experimento, como demonstrado na Equação 10:

$$
J=\frac{\Delta m}{\Delta t \cdot A}\left(\frac{g}{h \cdot m^{2}}\right)
$$

Equação 10

Considerando a primeira lei de Fick, proporcionalidade entre fluxo de matéria e gradiente de concentração, calcula-se a taxa de permeação de vapor de água através da Equação 11:

$$
P_{H_{2} O_{(V)}}=\frac{J L}{\Delta P_{V}(T)}\left(\frac{g}{\text { Pa.s.m }}\right) \quad \text { Equação } 11
$$

onde $L$ é a espessura da membrana, e $\Delta P_{V}(T)$ a variação de pressão de vapor de água a uma dada temperatura.

\subsubsection{ENSAIO DE PERMEAÇÃO DOS GASES $\mathrm{O}_{2} / \mathrm{CO}_{2}$}

Os ensaios de permeação dos gases oxigênio $\left(\mathrm{O}_{2}:\right.$ 6.0, pureza $\left.99.999 \%\right)$ e dióxido de carbono $\left(\mathrm{CO}_{2}\right.$ : 5.0, pureza 99.999\%), ambos adquiridos de White Martins, foram realizados, à pressão de $2 \mathrm{~atm}$, com a finalidade de avaliar a seletividade $\mathrm{O}_{2} / \mathrm{CO}_{2}$, comparativamente, entre as membranas de PEI.

O preparo da amostra consiste em fixar a membrana entre duas máscaras de fita de alumínio (silver tape) e fixar essa amostra, com adesivo epóxi, no interior de uma célula de metal com vedação tipo $O$-ring, Figura 9. 
Figura 9. Representação esquemática da célula de permeação.

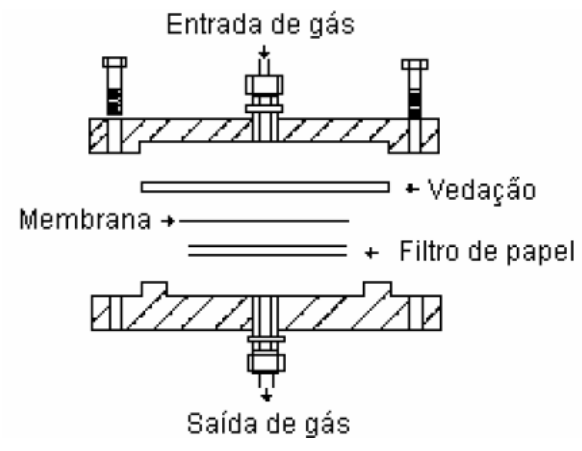

Fonte: Vedovello (2017)

Os ensaios foram realizados em um sistema de permeação a volume constante/pressão variável, localizado no Laboratório de Permeação e Sorção do Departamento de Engenharia de Materiais da UFSCar, composta pela célula de metal que contém a amostra; dois reservatórios de gás (superior e inferior); manômetro; e transdutor de pressão, como ilustrado na Figura 10.

Figura 10. Representação esquemática do sistema de permeação a gás.

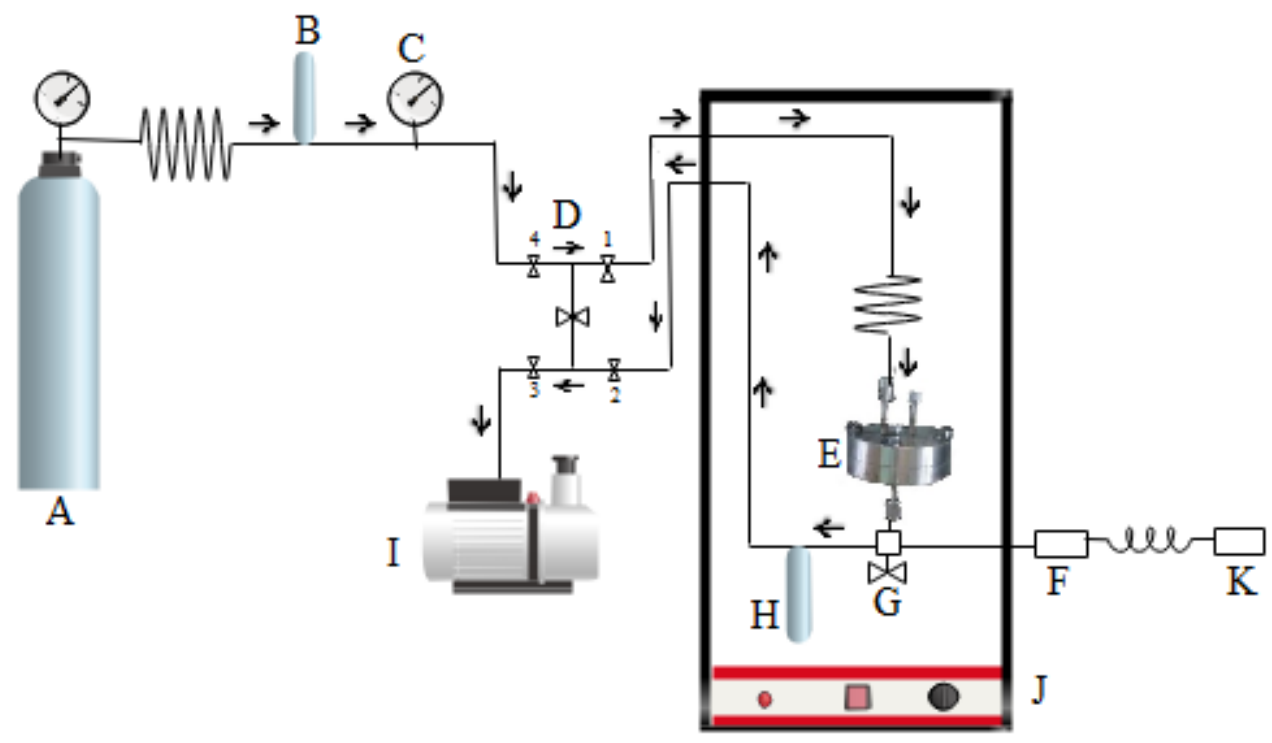

*Sendo: (A) Cilindro de gás; (B) Reservatório de gás (upstream); (C) Manômetro; (D) Conjunto de válvulas; (E) Célula de permeação; (F) Transdutor de pressão; (G) Válvula de alívio com disco de ruptura; (H) Reservatório de gás (downstream); (I) Bomba de vácuo; (J); Estufa com temperatura controlada; (K) Registrador de pressão.

Fonte: Vedovello (2017) 
Anteriormente ao início do ensaio, todo o sistema é evacuado por um período de 48 horas. O gás a ser testado provém do reservatório superior, ligado à tubulação de alimentação do sistema (upstream) por meio de válvulas e com um manômetro acoplado para informar a pressão do gás na linha. O gás passa pela célula de permeação, onde está a amostra, e segue para o reservatório inferior, que está acoplado a um transdutor de pressão, o qual monitora a variação da pressão (proporcional a quantidade de gás que atravessa a membrana) em relação ao tempo.

Através da determinação da taxa da pressão $(d p / d t)$, se obtém a taxa de permeância de cada gás, como mostrado na Equação 12;

$$
P=\frac{d p}{d t}\left(\frac{\text { torr }}{s}\right) \cdot \frac{V_{D}}{760}\left(\frac{\mathrm{cm}^{3}}{\text { torr }}\right) \cdot \frac{1}{A\left(\mathrm{~cm}^{2}\right) P(\mathrm{~cm} \mathrm{hg})} \cdot 10^{6}=\frac{\mathrm{cm}^{3} \cdot 10^{6}}{\mathrm{~s} \cdot \mathrm{cm}^{2} \cdot \mathrm{cmHg}} G P U
$$

Equação 12

onde $V_{D}$ é o volume do reservatório inferior, $A$ é a área da membrana empregada no ensaio e $P$ é a pressão do upstream, ou seja, a pressão do gás aplicada na entrada a célula de permeação.

A partir dos valores de permeância é possível calcular a seletividade $\mathrm{O}_{2} / \mathrm{CO}_{2}$ de cada membrana de PEI produzida através de planejamento experimental;

$$
\alpha=\frac{P O_{2}}{P C O_{2}}
$$




\subsubsection{ANÁLISE ESTATÍSTICA}

Foi empregado tratamento matemático-estatístico aos dados experimentais obtidos através das análises de transporte: TVA e permeação aos gases $\mathrm{O}_{2} \mathrm{e} \mathrm{CO}_{2}$. O tratamento consistiu no ajuste de uma função polinomial empírica, Equação 14, ao conjunto de dados experimentais, por meio de regressão linear múltipla, método dos mínimos quadrados.

$$
Y=b_{0}+\sum_{i=1}^{k} b_{i} X_{i}+\sum_{i<j}^{k} b i j X i X j+\varepsilon
$$

onde $Y=$ função genérica; $b=$ coeficientes estimados a partir do método dos mínimos quadrados; $X=$ variáveis codificadas e $\varepsilon=$ erro experimental.

Para avaliar a qualidade do ajuste do modelo matemático foi utilizado o método da Análise de Variância (ANOVA), a partir da análise de resíduos a 95\% de limite de confiança $(p<0,05)$. A significância estatística dos coeficientes do modelo foi avaliada pelo teste $\mathrm{F}$ e valor de probabilidade (valor- $p$ ), que foi adotado $p \leq 0,05$ para todos os ensaios.

Com a finalidade de avaliar a influência das variáveis independentes nas variáveis resposta, superfícies de resposta foram construídas a partir dos modelos matemáticos obtidos através do tratamento estatístico. A estatística e os gráficos tridimensionais foram processados com o emprego do Software Statistica for Windows versão 10.0 da StatSoft. 


\section{Resultados e discussão}

\subsection{Microscopia Eletrônica de Varredura}

Na Figura 11 estão apresentadas as micrografias das oito membranas obtidas, baseadas em planejamento experimental. Observam-se perfis bastante diferentes, em relação às suas morfologias, porém, nota-se que todas apresentaram estrutura típica assimétrica; com presença de poros em macro e microescala.

As membranas apresentaram morfologias diversas, uma vez que cada experimento foi realizado sob uma condição única, de acordo com o planejamento experimental, porém algumas tendências puderam ser notadas. Nas membranas PEI 1, PEI 2, PEI 3 e PEI 4 (micrografias de A a D, na Figura 11) pode-se observar a formação de macroporos com estruturas alongadas, do tipo finger like, abundantes, correspondendo a maior parcela das membranas. Nas outras membranas, PEI 5, PEI 6, PEI 7 e PEI 8 (micrografias de E a H, na Figura 11) observa-se a ocorrência de macroporos com formato arredondado ou em gota, e em pequena quantidade, os quais se encontram dispersos em uma "matriz" com morfologia microporosa, conhecida como sponge like.

O planejamento experimental que precedeu a produção das membranas teve como variáveis: a temperatura do banho de coagulação (V1); a espessura úmida das membranas (V2) e a concentração da solução polimérica (V3), e de acordo com a combinação das variáveis, que está apresentada na Tabela 3, as membranas PEI 1; PEI 2; PEI 3 e PEI 4 foram produzidas com solução polimérica $25 \%$, menos concentrada em relação a solução empregada para produzir as membranas PEI 5; PEI 6; PEI 7 e PEI 8. É importante ressaltar que todos os experimentos foram realizados por períodos de imersão idênticos. Então, pode-se sugerir a influência da concentração no perfil morfológico das membranas, em razão da viscosidade da solução polimérica, que é um importante parâmetro da técnica de inversão de fases, empregada neste trabalho.

De acordo com alguns autores (A. L. AHMAD; SALAUDEEN; JAWAD, 2017; SHAMSABADI; KARGARI; BABAHEIDARI; LAKI, 2013; SHAMSABADI; KARGARI; BABAHEIDARI; LAKI et al., 2013) a influência da concentração da solução polimérica na morfologia de membranas, obtidas pelo método de inversão de fases, está relacionada à viscosidade, e a concentração crítica de solução, exclusiva do par polímero-solvente. 
Figura 11. Micrografia das seç̧̃̃es transversais das membranas de PEI produzidas a partir de planejamento experimental.

A.

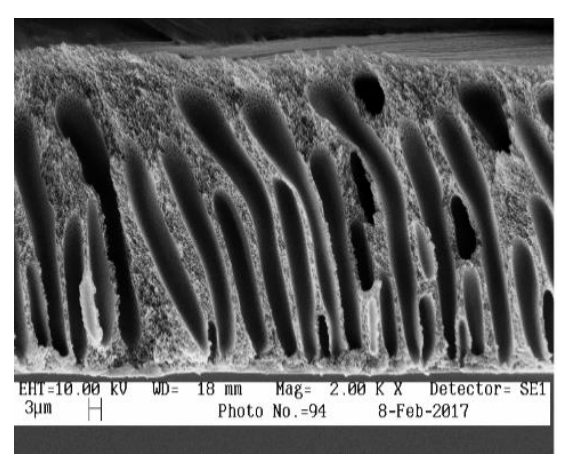

E.

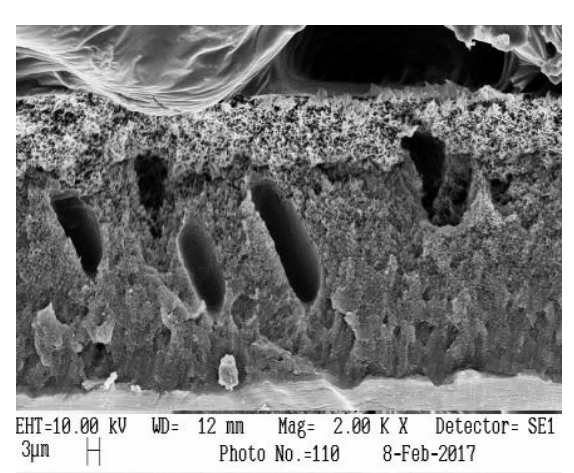

B.

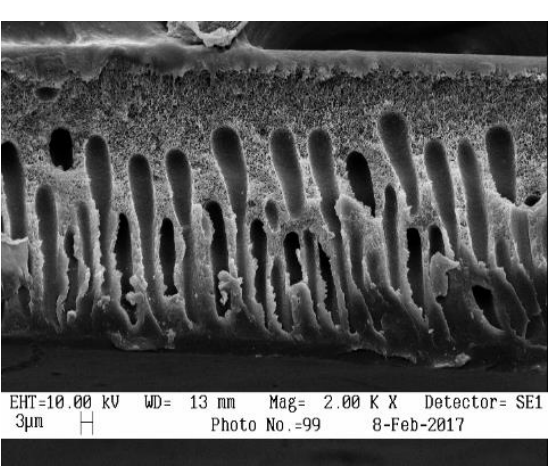

F.

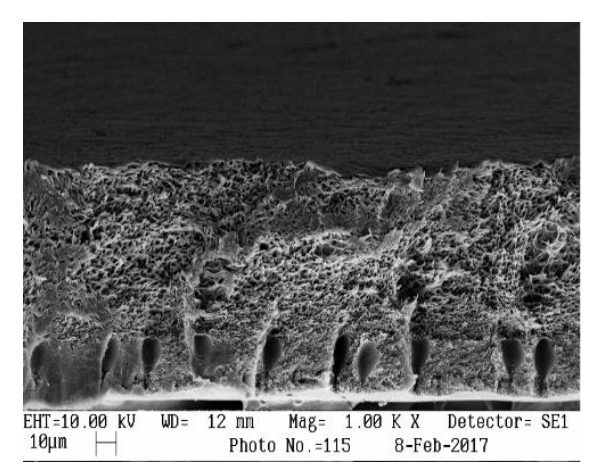

C.

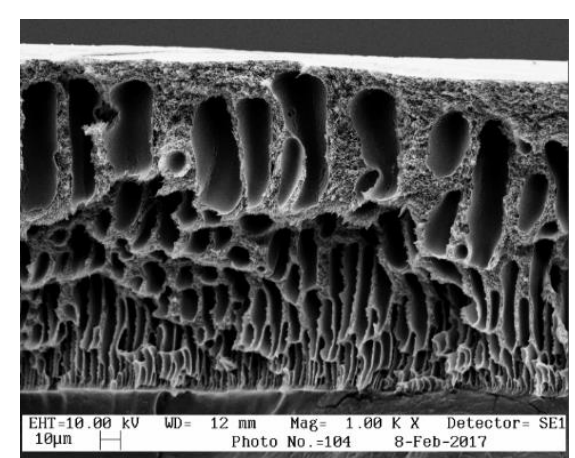

G.

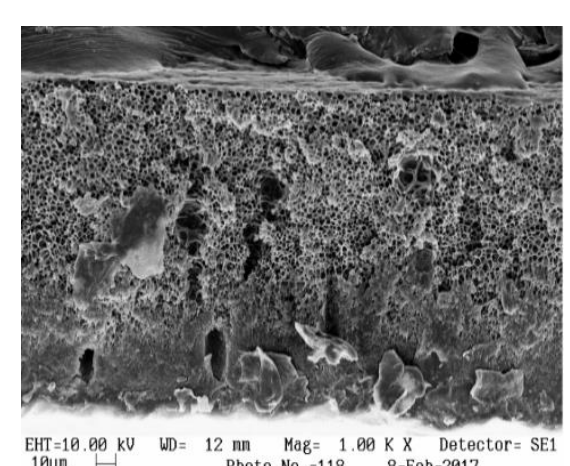

D.

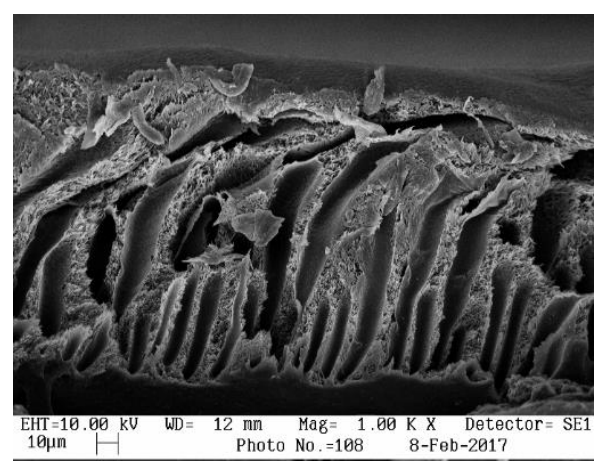

H.

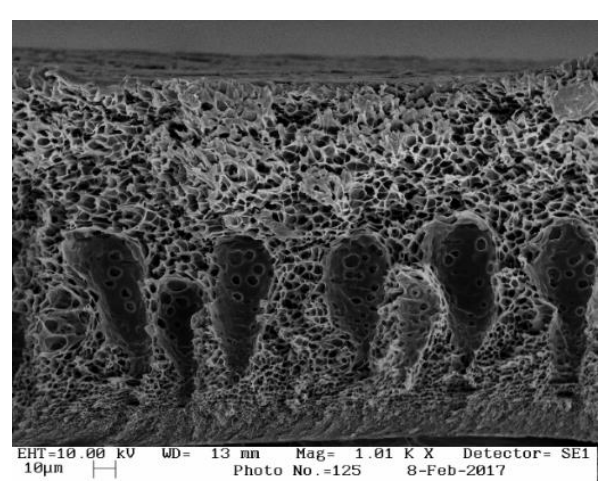

Sendo: A. Membrana PEI 1; B. Membrana PEI 2; C. Membrana PEI 3; D. Membrana PEI 4; E. Membrana PEI 5; F. Membrana PEI 6; G. Membrana PEI 7; H. Membrana PEI 8 
Por meio de experimentos, os autores mostraram que, a uma determinada temperatura, existe uma concentração de solução PEI - NMP, em que a viscosidade sofre um aumento significativo e súbito brusco, resultando em uma configuração de emaranhamento das cadeias poliméricas, e, por consequência, diminuição na mobilidade. Nos experimentos citados o valor crítico de concentração de solução PEI - NMP encontrado ficou na faixa de 23 a $24 \%$ (m/m), muito próximos aos da concentração de $25 \%$ utilizada para as amostras PEI 1-4

Transportando esse raciocínio para o processo da inversão de fases, que consiste em imergir a solução polimérica em um banho de coagulação, onde ocorre deslocamento de solventes líquidos (no caso deste trabalho NMP e água), pode-se prever que para as soluções com concentrações acima do valor crítico, em razão da alta viscosidade e pouca mobilidade das cadeias poliméricas, o início da precipitação ocorre rapidamente, formando uma barreira física à entrada de água na solução. Assim ${ }_{2}$ as trocas entre solventes serão mais dificultadas, atrasando a remoção do solvente. O resultado é a formação de estrutura microporosa, tipo sponge like com poucos macroporos, ser favorecida, já que para a formação dos macroporos é necessária a formação das chamadas "áreas pobres" em polímero, ou locais vazios, que são formados pela presença de água, solvente e baixa concentração de polímero na solução polimérica. (BAKER, 2001b).

Essa é uma provável explicação para a tendência de formação observada entre as membranas apresentadas na Figura 11. Aquelas que foram produzidas com solução polimérica menos concentrada (PEI 1 a PEI 4), provavelmente apresentam conformação molecular com menor empacotamento de cadeias poliméricas, que favorecem a entrada e a difusão de moléculas de água na solução polimérica. Assim a etapa de troca de solventes, durante a precipitação, favorece a formação de macroporos. O contrário ocorreu com as membranas produzida com solução polimérica mais concentrada (PEI 5 a PEI 8), lenta entrada de água durante a etapa de troca de solventes, favorecendo a formação de uma camada superficial microporosa espessa e poucos macroporos.

A membrana PEI 1 apresentou morfologia com grande incidência de poros tipo finger like que se formam próximos à superfície e se estendem através da membrana. A matriz é formada por estrutura microporosa, que possui poros muito pequenos e abundantes, (sponge like) e forma uma espécie de camada na superfície contrária à da superfície de origem dos poros. A membrana PEI 2 tem morfologia similar à da membrana PEI 1, apresentando a camada formada pela matriz sponge like mais espessa. De acordo com o planejamento experimental, as condições de produção das membranas PEI 1 - PEI 2 diferenciam apenas em relação a 
temperatura do banho de coagulação. O mesmo ocorre entre as membranas PEI 3 - PEI 4, observa-se pelas micrografias C e D na Figura 11, que a morfologia das membranas difere em relação a forma e ocorrência dos macroporos.

Na membrana PEI 3 pode-se observar macroporos abundantes e de tamanhos diversos e fina camada de matriz microporosa, já na membrana PEI 4 pode-se notar a presença de poros com configuração que se assemelha a canais, mais finos e estendidos, de uma superfície a outra. O que sugere que as variáveis temperatura do banho de coagulação e espessura úmida tenham influência no processo de formação das membranas.

Entre os pares de membranas PEI 5 - PEI 6 e PEI 7 - PEI 8 não foi possível observar tendência de formação decorrente, unicamente, da variação da temperatura do banho de coagulação. No caso do primeiro par, observa-se a diminuição do tamanho dos poros com o aumento da temperatura, já no caso do segundo par, observa-se aumento no tamanho dos poros com o aumento da temperatura. Porém, pode-se notar que a combinação das variáveis temperatura do banho de coagulação e concentração da solução polimérica no nível superior produz membranas mais espessas. A membrana PEI 6 apresenta espessura duas vezes maior que PEI 5, a mesma tendência se observa para PEI 7 e PEI 8, Tabela 3.

Tabela 3. Condições experimentais e espessura das membranas obtidas por planejamento experimental.

\begin{tabular}{lcccc}
\hline & \multicolumn{3}{c}{ Condições experimentais } & Espessura \\
\cline { 2 - 3 } & $\begin{array}{c}\text { Temp. } \\
\text { coagulação }\left({ }^{\circ} \mathrm{C}\right)\end{array}$ & $\begin{array}{c}\text { Espessura úmida } \\
(\mu \mathrm{m})\end{array}$ & $\begin{array}{c}\text { Conc. }(\%) \\
\text { sol. polimérica } \\
(\mathrm{m} / \mathrm{m})\end{array}$ & $\begin{array}{c}\text { seca } \\
(\boldsymbol{\mu m})\end{array}$ \\
\hline \hline PEI 1 & 25 & 100 & 25 & $70 \pm 20$ \\
PEI 2 & 65 & 100 & 25 & $70 \pm 10$ \\
PEI 3 & 25 & 300 & 25 & $170 \pm 0$ \\
PEI 4 & 65 & 300 & 25 & $190 \pm 10$ \\
PEI 5 & 25 & 100 & 35 & $60 \pm 10$ \\
PEI 6 & 65 & 100 & 35 & $120 \pm 10$ \\
PEI 7 & 25 & 300 & 35 & $170 \pm 20$ \\
PEI 8 & 65 & 300 & 35 & $250 \pm 40$ \\
\hline \hline
\end{tabular}


Na Tabela 3 encontram-se os valores das espessuras das membranas secas. Pode-se observar que entre os pares de membranas PEI 1 - PEI 2 e PEI 3 - PEI 4 (V3 = 25\%) o aumento da temperatura do banho não implica em aumento significativo da espessura seca das membranas. Já, para os pares PEI 5 - PEI 6 e PEI 7 - PEI 8 (V3=35\%), pode-se verificar o aumento da espessura seca com aumento da temperatura do banho.

Na comparação entre os pares de membranas PEI 2 - PEI 6 e PEI 4 - PEI 8 nota-se que houve aumento significativo da espessura da membrana seca com o aumento da concentração da solução polimérica. Estas membranas foram produzidas no nível superior da V1. O aumento da concentração da solução não produziu variação significativa na espessura dos pares PEI 1 PEI 5 e PEI 3 - PEI 7, que foram produzidas no nível inferior da V1. Sugerindo a seguinte contribuição: combinação das variáveis V1 e V3 no nível superior produz membranas mais espessas.

Ao avaliar a possível influência da V2, na formação das membranas, foram considerados alguns perfis morfológicos, relacionados a espessura, maior quantidade de poros, tamanho de poros variados e camada microporosa (sponge like) mais espessa decorrente do aumento da espessura (ABDUL LATIF AHMAD; OLATUNJI; JAWAD, 2017; D. LI et al., 2004).

Comparando-se a morfologia entre as membranas PEI 1 e PEI 3 nota-se que houve aumento de heterogeneidade dos poros com o aumento da espessura. Entre as membranas PEI 2 e PEI 4 houve mudança na morfologia dos poros. Entre as PEI 5 e PEI 7 houve aumento da matriz microporosa e entre as PEI 6 e PEI 8 houve aumento no tamanho dos macroporos, efeitos isolados que não permitem estabelecer uma tendência, portanto, conclui-se que a espessura úmida é uma variável que apenas impacta a espessura seca das membranas obtidas.

\section{2 Ângulo de contato}

Na Tabela 4 estão compilados os valores dos ângulos de contato referentes às membranas de PEI produzidas por meio de planejamento experimental. Na produção das membranas foram denominadas, por convenção, faces inferiores, as superfícies que ficaram em contato com o suporte de vidro. 
Tabela 4. Valores de ângulo de contato obtidos pelo método da gota séssil no modo estático.

\begin{tabular}{ccc}
\hline Amostra & $\begin{array}{c}\text { Ângulo de contato (superior) } \\
\left({ }^{\circ}\right)\end{array}$ & $\begin{array}{c}\text { Angulo de contato (inferior) } \\
\left({ }^{\circ}\right)\end{array}$ \\
\hline \hline PEI 1 & $71 \pm 3$ & $71 \pm 9$ \\
PEI 2 & $88 \pm 2$ & $77 \pm 4$ \\
PEI 3 & $80 \pm 4$ & $77 \pm 4$ \\
PEI 4 & $93 \pm 7$ & $86 \pm 3$ \\
PEI 5 & $77 \pm 11$ & $82 \pm 10$ \\
PEI 6 & $81 \pm 2$ & $76 \pm 4$ \\
PEI 7 & $83 \pm 3$ & $72 \pm 6$ \\
PEI 8 & $66 \pm 5$ & $65 \pm 7$ \\
\hline \hline
\end{tabular}

Todas as membranas planejadas experimentalmente foram produzidas com os mesmos materiais; PEI e NMP, diferindo apenas nas concentrações das soluções. Assim, em relação a propriedades que poderiam influenciar no "espalhamento" da água sobre a superfície das membranas, como hidrofilicidade, sugere-se que não haja diferença entre as amostras analisadas.

Observa-se que diferentes valores de ângulo de contato foram encontrados para cada face, inferior e superior, da mesma membrana. Esta variação é devida, provavelmente, a características topográficas das superfícies das membranas, como a rugosidade. Esta característica é fortemente influenciada pela técnica de produção.

É válido lembrar, que neste trabalho, as membranas são formadas com uma de suas faces em contato com o suporte, e a outra em contato com a água. Além de serem, cada uma das oito membranas, obtidas por uma combinação única das variáveis: $a$ ) temperatura do banho, b) espessura úmida e $c$ ) concentração da solução polimérica, que podem influenciar a morfologia das diferentes faces da mesma membrana, tanto quanto promover diferenças nas morfologias entre elas.

Na comparação entre faces da mesma membrana pode-se observar que as mostras PEI 2, PEI 4, PEI 5 e PEI 7 apresentaram variações nos valores de ângulos de contato iguais ou superiores a $5^{\circ}$ entre suas faces. Para as membranas PEI 1, PEI 3, PEI 6 e PEI 8 ocorreu o contrário; variações menores que $5^{\circ}$. Não foi possível traçar nenhuma tendência entre as membranas pertencentes aos grupos de amostras supracitados, por não haver variável experimental ou característica morfológica em comum a todos os integrantes, em cada grupo. 
Observa-se para as membranas PEI 1 e PEI 4, a partir dos valores de desvio, que uma das faces apresenta sua topografia mais heterogêneas, e/ou, possivelmente, com defeitos superficiais em microescala, comparada a outra face. No caso da membrana PEI 5, que apresentou valores elevados de desvio para ambas as faces, provavelmente possui topografia heterogênea, e/ou possivelmente defeitos superficiais em microescala, em ambas.

As diferenças de valores de ângulo médio de contato entre as membranas também são decorrentes, provavelmente, das diferenças topográficas de suas superfícies.

Bakeri et al. (2012) mediram valor de 80,6 $6^{\circ}$ de ângulo de contato, para membrana de contato produzida com PEI e NMP; Qtaishat et al. (2009) relataram os valores $80,04^{\circ}$ e $72,83^{\circ}$ para os ângulos de contato das faces superior e inferior, respectivamente, de membranas planas assimétricas de PEI e NMP, o que reforça a hipótese de que as características topográficas são bastante influentes na formação do ângulo de contato entre uma gota e uma superfície sólida.

Observa-se que tanto os valores experimentais obtidos neste trabalho quanto aqueles previamente relatados não ficaram abaixo de $60^{\circ}$, o que indica um caráter hidrofóbico para membranas de PEI.

\subsection{Ensaios de transporte e Análise estatística}

Os resultados obtidos nas análises de transporte (TVA) e Permeação de gases, variáveis resposta, estão compilados na Tabela 5, onde também se encontram os valores decodificados das variáveis independentes empregadas no planejamento experimental. A fim de avaliar a permeação do gás $\mathrm{O}_{2}$ relativa a permeação do gás $\mathrm{CO}_{2}$, os resultados desta análise de transporte foram apresentados na forma de fator de separação $\left(\alpha=\mathrm{PO}_{2} / \mathrm{PCO}_{2}\right)$. 
Tabela 5. Planejamento experimental completo em dois níveis (valores decodificados) e resultados experimentais das análises de transporte.

\begin{tabular}{cccccc}
\hline Ensaio & \multicolumn{3}{c}{ Variáveis independentes } & \multicolumn{2}{c}{ Variáveis Resposta $^{a}$} \\
\cline { 2 - 6 } & Temp. banho & Espessura & Conc. Sol. & Fator de & Permeação $\mathrm{H}_{2} \mathrm{O}(\mathrm{v})$ \\
& $\left({ }^{\circ} \mathrm{C}\right)$ & $(\mu \mathrm{m})$ & Pol. & separação & $(\mathrm{exp}-10)[\mathrm{g} / \mathrm{Pa} . \mathrm{s} . \mathrm{m}]$ \\
& & & $(\% \mathrm{~m} / \mathrm{m})$ & $\mathrm{O}_{2} / \mathrm{CO}_{2(\mathrm{~g})}$ & \\
$\mathbf{1}$ & 25 & 100 & 25 & $0,57 \pm 0,14$ & $2,54 \pm 0,03$ \\
$\mathbf{2}$ & 65 & 100 & 25 & $0,53 \pm 0,12$ & $2,21 \pm 0,05$ \\
$\mathbf{3}$ & 25 & 300 & 25 & $0,59 \pm 0,10$ & $4,40 \pm 0,89$ \\
$\mathbf{4}$ & 65 & 300 & 25 & $0,79 \pm 0,03$ & $3,96 \pm 0,17$ \\
$\mathbf{5}$ & 25 & 100 & 35 & $0,83 \pm 0,24$ & $0,42 \pm 0,21$ \\
$\mathbf{6}$ & 65 & 100 & 35 & $0,94 \pm 0,22$ & $2,17 \pm 0,25$ \\
$\mathbf{7}$ & 25 & 300 & 35 & $0,44 \pm 0,00$ & $0,88 \pm 0,22$ \\
$\mathbf{8}$ & 65 & 300 & 35 & $0,67 \pm 0,09$ & $2,67 \pm 0,07$ \\
\hline \hline
\end{tabular}

$a=$ Valores médios e desvio padrão de duas repetições.

Para a análise de TVA observa-se que os valores obtidos para permeação de vapor de água variam entre 0,040 a 0,440 ng/Pa.s.m, para a análise de permeação de gases observa-se que o fator de separação $\mathrm{O}_{2} / \mathrm{CO}_{2(\mathrm{~g})}$ variou entre 0,44 e 0,94 . Fica indicado que os fatores escolhidos para compor o planejamento experimental influenciam o processo de obtenção das membranas, impactando tanto suas morfologias, como apontado e discutido nas seções 5.1 e 5.2, quanto suas propriedades, por consequência.

Visando descrever a relação entre as variáveis dependentes e independentes a Equação 14, seção 3.3.3.3, foi ajustada aos dados experimentais, por regressão linear múltipla. O ajuste do modelo foi avaliado com base no quadro ANOVA, Tabela 6, através do qual pode-se verificar quais termos foram significativos ao nível de 95\% de significância combinado a probabilidade de $5 \%$ ( $p$-valor $<0,05)$. 
Tabela 6. Análise de variância para as análises de transporte: permeação ao vapor de água e aos gases $\mathrm{O} 2$ e $\mathrm{CO} 2$.

\begin{tabular}{ccccc}
\hline \hline Termos & \multicolumn{2}{c}{ Permeação $\mathbf{H}_{\mathbf{2}} \mathbf{O}(\mathbf{v})$} & \multicolumn{2}{c}{ Fator de separação $\mathbf{O}_{2} / \mathbf{C O}_{2}$} \\
\cline { 2 - 5 } $\mathbf{X}_{\mathbf{1}}$ & $\mathrm{F}$ & $p$-value & $\mathrm{F}$ & $p$-value \\
\cline { 2 - 5 } $\mathbf{X}_{\mathbf{2}}$ & $15,5^{*}$ & $0,0043^{*}$ & 2,99 & 0,122 \\
$\mathbf{X}_{\mathbf{3}}$ & $42,5^{*}$ & $0,0002^{*}$ & 1,83 & 0,213 \\
$\mathbf{X}_{\mathbf{1}} \mathbf{X}_{\mathbf{2}}$ & $98,8^{*}$ & $0,0000^{*}$ & 2,02 & 0,193 \\
$\mathbf{X}_{\mathbf{1}} \mathbf{X}_{\mathbf{3}}$ & 0,00 & 0,9395 & 1,68 & 0,231 \\
$\mathbf{X}_{\mathbf{2}} \mathbf{X}_{\mathbf{3}}$ & $37,8^{*}$ & $0,0003^{*}$ & 0,43 & 0,530 \\
Falta de ajuste & $14,3^{*}$ & $0,0054^{*}$ & $11,0 *$ & $0,0105^{*}$ \\
\hline $\mathbf{R}^{\mathbf{2}}$ & 0,05 & 0,8307 & 0,18 & 0,685 \\
$\mathbf{R}^{\mathbf{2}}$ adj. & 0,9629 & & 0,7096 & \\
$\mathbf{X}^{2}=$ & 0,9382 & & 0,5160 &
\end{tabular}

$\mathrm{X}_{1}^{\mathrm{a}}=$ Temperatura do banho de coagulação; $\mathrm{X}_{2}^{\mathrm{a}}=$ espessura úmida da membrana; $\mathrm{X}_{3}^{\mathrm{a}}=$ Concentração da solução polimérica; * = Valores significativos ao nível $5 \%$ de probabilidade $(p<0,05)$

Observa-se a influência dos termos nos valores de permeação de vapor de água na seguinte ordem de significância $(p<0)$ :

$$
\mathrm{X}_{3}>\mathrm{X}_{2}>\mathrm{X}_{1} \mathrm{X}_{3}>\mathrm{X}_{1}>\mathrm{X}_{2} \mathrm{X}_{3}
$$

Pode-se afirmar, então, que o termo $\mathrm{X}_{3}$ exerce maior influência sobre esta resposta, assim como o termo $\mathrm{X}_{2} \mathrm{X}_{3}$ exerce a menor, e o termo $\mathrm{X}_{1} \mathrm{X}_{2}$ não exerceu influência significativa $(p>0,05)$ nesta resposta.

Também é possível verificar, no quadro ANOVA, que não houve falta de ajuste dos modelos $(p>0,05)$, indicando adequação do modelo matemático linear ao conjunto de dados. $\mathrm{O}$ valor do coeficiente de determinação do modelo matemático $\left(\mathrm{R}^{2}\right.$ adj $)$ para a análise de permeação de vapor de água (TVA) indica que 93,8\% da variação total em torno da média é explicada pela regressão linear, e pequena porcentagem é referente aos resíduos. A partir dessa análise, modelos polinomiais que expressam a relação entre as variáveis independente e dependentes foram elaborados. A Equação 15 representa o modelo polinomial para a variável resposta permeação do vapor de água. 


$$
P_{H_{2} O_{V}}=8,98-0,14 X_{1}+0,03 X_{2}-0,28 X_{3}+0,05 X_{1} X_{3}-0,0007 X_{2} X_{3} \quad \text { Equação } 15
$$

Sobre os valores da variável resposta fator de separação, verifica-se, no quadro ANOVA, que a única influência significativa $(p<0,05)$ foi a do termo $\mathrm{X}_{2} \mathrm{X}_{3}$, e todos os outros termos, inclusive o correspondente a falta de ajuste, não exerceram influência significativa ( $p$ $>0,05)$, indicando o ajuste do modelo matemático linear ao conjunto de dados. Essa análise gerou o modelo polinomial da Equação 16.

$$
\alpha_{O_{2} / \mathrm{CO}_{2}}=-0,564+0,006 X_{2}-0,0002 X_{2} X_{3} \quad \text { Equação } 16
$$

$\mathrm{O}$ valor de $\mathrm{R}_{\text {adj }}^{2}$ foi de $51,6 \%$, ou seja, essa foi a porcentagem da variação total em torno da média que a regressão linear conseguiu explicar, os outros 48,4\% são atribuídos aos resíduos.

Através dos modelos polinomiais, foram obtidas superfícies de resposta, a partir dos valores reais das variáveis independentes, Figura 12. Nos gráficos tridimensionais, a variável resposta corresponde ao eixo Z, enquanto duas das variáveis independentes são plotadas nos eixos $\mathrm{X}$ e Y, e a terceira variável independente é fixada no valor zero.

Na superfície de resposta A. da Figura 12 nota-se que o valor da variável resposta; permeação de vapor de água, tende a aumentar quando a temperatura do banho de coagulação se encontra no seu nível mínimo $\left(25^{\circ} \mathrm{C}\right)$, e a espessura úmida da membrana se encontra no seu nível máximo $(300 \mu \mathrm{m})$. Na superfície de resposta B. observa-se que a permeação tende a aumentar quando tanto a temperatura do banho de coagulação quanto a concentração de solução polimérica se encontram em seus níveis mínimos. E, por fim, na superfície de resposta C, verifica-se que o aumento da permeação ocorre quando a variável espessura úmida da membrana se encontra no seu nível máximo $(300 \mu \mathrm{m})$ e a concentração de solução polimérica se encontra no seu nível mínimo (25\%). Conclui-se, portanto, que a variável 1 e a variável 3 empregadas nos seus níveis mínimos $\left(25^{\circ} \mathrm{C}\right.$ e $25 \%$, respectivamente) e a variável 2 no seu nível máximo $(300 \mu \mathrm{m})$ no planejamento experimental, produzem membranas mais susceptíveis à permeação de água na forma de vapor. 
Figura 12. Superfície de resposta da interação entre as variáveis V1(temperatura do banho de imersão) e V2 (espessura úmida da membrana de PEI) e V3 (concentração da solução de PEI).

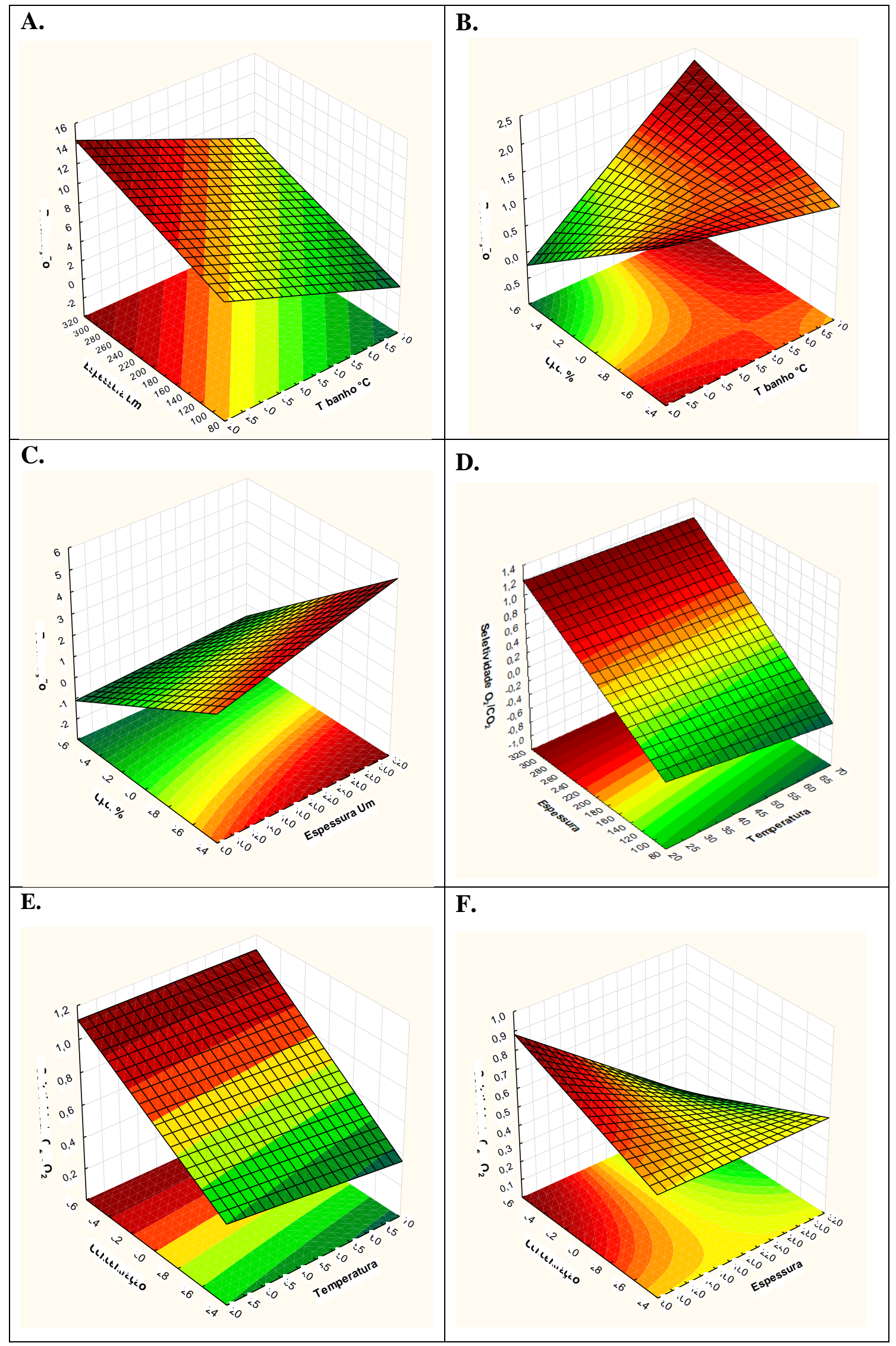


Na superfície de resposta D da Figura 12 nota-se que o valor da variável resposta fator de separação $\mathrm{O}_{2} / \mathrm{CO}_{2}$, que corresponde, teoricamente, a seletividade da membrana, tende a aumentar quando a espessura úmida se encontra no seu nível máximo $(300 \mu \mathrm{m})$. Por outro lado, a temperatura do banho de coagulação não exerce influência perceptível nesta variável resposta. Da mesma forma, na superfície de resposta E, observa-se que o valor do fator de separação $\mathrm{O}_{2} / \mathrm{CO}_{2}$ tende a aumentar quando a concentração de solução polimérica se encontra no seu nível máximo (35\%) ao passo que a temperatura do banho de coagulação, novamente, não exerce influência perceptível na variável resposta. E, por fim, na superfície de resposta $\mathrm{F}$ verifica-se que o aumento d o valor do fator de separação $\mathrm{O}_{2} / \mathrm{CO}_{2}$ ocorre quando a espessura úmida se encontra no seu nível mínimo $(100 \mu \mathrm{m})$ e a concentração de solução polimérica se encontra no seu nível máximo (35\%).

Portanto as variáveis 2 e 3 empregadas, separadamente, nos seus níveis máximos no planejamento experimental produzem membranas que apresentam altos valores de fator de separaçãoO $\mathrm{O}_{2} / \mathrm{CO}_{2}$. Quando são empregadas combinadas, produzem maiores valores da variável resposta se a variável 2 tender ao seu nível mínimo e a variável 3 ao seu nível máximo.

Sugere-se, a partir desta análise, que para a obtenção de membranas mais permeáveis ao vapor de água a melhor condição de produção é a combinação das variáveis V1 no nível mínimo $\left(25^{\circ} \mathrm{C}\right)$, V2 no nível máximo $(300 \mu \mathrm{m})$ e V3 no nível mínimo $(25 \%)$, que corresponde ao experimento PEI 3 do planejamento experimental. Já para a obtenção de membranas com maiores valores do fator de separação $\mathrm{O}_{2} / \mathrm{CO}_{2}$ conclui-se que em razão de a $\mathrm{V} 1$ não produzir influência significativa, a influência das outras duas varáveis combinadas, o efeito V2V3, deve ser considerado como maior responsável pela resposta obtida, o que corrobora os resultados obtidos a partir da análise estatística. Sendo assim, a melhor condição experimental de produção é o emprego da V2 no nível mínimo $(100 \mu \mathrm{m})$ e da V3 no nível máximo (35\%), que corresponde aos experimentos 5 e 6 do planejamento experimental.

Esta conclusão é corroborada pela análise de MEV, apresentada na seção 5.1, onde é possível visualizar que as membranas produzidas a partir das condições supracitadas, na ordem: PEI 3, PEI 5 e PEI 6, correspondentes às imagens C., E. e F. da Figura 10, apresentam morfologias muito diferentes. Enquanto a membrana PEI 3 se caracteriza por ser heterogeneamente porosa, as membranas PEI 5 e PEI 6 se apresentam com menor heterogeneidade, marcada por microporosidade e presença diminuída de macroporos. 
A membrana PEI 4 apresentou bons resultados para ambos os ensaios de transporte. Uma possível explicação para esse comportamento é a exclusiva morfologia desta membrana, que foi a única composta, apenas, por poros alongados, similares a canais, por toda sua extensão e fina camada superficial. A fina camada da superfície favorece a sorção das moléculas, e os poros estreitos e alongados permitem a difusão tanto de moléculas de água (vapor) quanto de moléculas dos gases $\mathrm{O}_{2}$ e $\mathrm{CO}_{2}$.

Tais constatações levam a crer que em membranas com maior incidência de macroporos o transporte de massa é mais facilitado, enquanto em membranas com poros mais fechados, o transporte de massa é menos incidente e a seletividade passa a ser uma característica mais marcante da membrana (A. L. AHMAD; SALAUDEEN; JAWAD, 2017; SHAMSABADI; KARGARI; BABAHEIDARI; LAKI et al., 2013). Contudo, em relação aos resultados obtidos neste trabalho, não se pode classificar nenhuma das membranas obtidas como seletivas ao par gasoso $\mathrm{O}_{2} / \mathrm{CO}_{2}$, pois nenhuma das membranas apresentou permeação do gás $\mathrm{O}_{2}$ superior a permeação do $\mathrm{CO}_{2}$, de acordo com o cálculo do fator de separação $\left(\alpha=\mathrm{PO}_{2} / \mathrm{PCO}_{2}\right)$, resultando em valores numéricos menores que a unidade para esta variável resposta. Valores de permeância dos gases $\mathrm{O}_{2}$ e $\mathrm{CO}_{2}$ obtidos paras as membranas produzidas neste trabalho e encontrados em referências estão compilados na Tabela 7.

Tabela 7. Valores de permeância (experimentais e de referência) para os gases $\mathrm{O} 2$ e CO2.

\begin{tabular}{|c|c|c|c|c|c|}
\hline \multirow[t]{2}{*}{ Amostra } & \multirow{2}{*}{$\begin{array}{l}\text { Permeância } \mathrm{O}_{2} \\
\text { (GPU) }\end{array}$} & \multirow{2}{*}{$\begin{array}{l}\text { Permeância } \mathrm{CO}_{2} \\
\text { (GPU) }\end{array}$} & \multirow[t]{2}{*}{ Amostra } & \multicolumn{2}{|c|}{ Permeância (GPU) } \\
\hline & & & & $\mathrm{O}_{2}$ & $\mathrm{CO}_{2}$ \\
\hline PEI1 & $7,20 \pm 0,50$ & $12,99 \pm 3,93$ & & & \\
\hline PEI2 & $1,56 \pm 0,58$ & $2,91 \pm 0,40$ & PEI ${ }^{\mathbf{a}}$ & 2,4 & \\
\hline PEI3 & $2,99 \pm 1,73$ & $4,86 \pm 2,05$ & & & \\
\hline PEI4 & $2,52 \pm 0,55$ & $3,18 \pm 0,56$ & & & \\
\hline PEI5 & $0,93 \pm 0,53$ & $1,06 \pm 0,32$ & PEI $\mathbf{I}^{\mathrm{b}}$ & & 6,35 \\
\hline PEI6 & $4,27 \pm 1,22$ & $4,50 \pm 0,25$ & & & \\
\hline PEI7 & $1,78 \pm 0,00$ & $4,03 \pm 0,00$ & & & \\
\hline PEI8 & $0,67 \pm 0,56$ & $1,06 \pm 0,97$ & & & \\
\hline
\end{tabular}

*PEI : referência KURDI; TREMBLAY (1999), PEI $^{\mathrm{b}}$ : referência AHMAD et al. (2017) 
Pode-se observar que a membrana PEI 8 apresentou os menores valores de permeância dos gases $\mathrm{O}_{2}$ e $\mathrm{CO}_{2}$ e a membrana PEI 1 apresentou os maiores valores. Tais membranas possuem morfologias opostas (Figura 10), sendo característica da PEI 1 expressiva incidência de macroporos, e PEI 8, morfologia microporosa dominante, corroborando discussão anterior.

Pode-se verificar que além de as citadas membranas apresentarem morfologias opostas, apresentam também condições experimentais de produção (Tabela 3) apostas. A concentração de solução polimérica, empregada na produção de membranas pelo método da inversão de fases, e a espessura da membrana são fatores que influenciam expressivamente as propriedades de transporte (AHMAD; OLATUNJI; JAWAD, 2017; SHAMSABADI et al., 2013a). O que explica os diferentes valores obtidos para as membranas obtidas neste trabalho.

Kurdi e Trembaly (KURDI; TREMBLAY, 1999) obtiveram o valor de 2,87 GPU para permeância do gás $\mathrm{O}_{2}$ em análise de separação de mistura $\mathrm{O}_{2} / \mathrm{CO}_{2}$ sob pressão de 6,9 bar, para membranas assimétricas de PEI obtidas a partir de solução PEI/NMP em concentração $(\mathrm{m} / \mathrm{m})$ 23\%/77\%. Ahmad et al(AHMAD; SALAUDEEN; JAWAD, 2017) obtiveram o valor de 6,35 GPU de permeância de $\mathrm{CO}_{2}$, em análise de permeação de gás puro, a 1 bar de pressão, para membranas assimétricas de PEI obtidas a partir de solução PEI/NMP em concentração $(\mathrm{m} / \mathrm{m})$ 30\%/70\%. As membranas PEI 3 e PEI 4 apresentaram valores de permeância de $\mathrm{O}_{2}$ mais próximos ao valor da referência encontrada e uma possível explicação é a semelhança entre as concentrações das soluções poliméricas empregadas na produção das mesmas, [PEI/NMP] $25 \% / 75 \%$ neste trabalho, [PEI/NMP] 23\%/77\% na referência.

No caso dos valores de permeância ao $\mathrm{CO}_{2}$, a amostra PEI1 apresentou maior valor em comparação às demais amostras e ao trabalho de Ahmad et al. Alqaheem e Alomair (ALQAHEEM; ALOMAIR, 2019) apresentaram uma revisão de valores de permeância ao $\mathrm{CO}_{2}$ para diferentes membranas, incluindo as obtidas de matrizes vítreas, como PEI, poli(imida) e policarbonato. Para estas membranas, valores entre 1,18 e 42 GPU foram apresentados. Faixa de valores similares foram relatados também por Chen et al (CHEN et al., 2015). O PEI possui importante capacidade de sorção de $\mathrm{CO}_{2}$ devido à presença dos grupos imida, o que justifica sua investigação para membranas visando a captura de $\mathrm{CO}_{2}$ (URIARTE; ALFAGEME; IRUIN, 1998). Pelo fato de ser um polímero vítreo, ou seja, possui temperatura de transição vítrea acima da temperatura ambiente, o PEI é significativamente resistente à plastificação pelo $\mathrm{CO}_{2}$. Logo, uma variável a ser considerada na análise dos resultados de permeância ao $\mathrm{CO}_{2}$ das membranas é a capacidade de sorção ao gás. Considerando as morfologias obtidas pelas amostras, corrobora-se que estruturas mais porosas são mais favoráveis à absorção de $\mathrm{CO}_{2}$ que as 
microporosas.

\section{Conclusão Parcial}

Pode-se concluir, desta primeira etapa do trabalho, que a variável concentração de solução polimérica tem grande influência sobre a morfologia das membranas, sendo observada a formação de membranas macroporosas a partir da produção de amostras com soluções $25 \%$ $(\mathrm{m} / \mathrm{m})$ PEI/NMP, valor próximo ao da concentração crítica, a $25{ }^{\circ} \mathrm{C}$, Assim como, as membranas produzidas a partir de solução 35\% (m/m) PEI/NMP, apresentaram morfologia microporosa, com poucos macroporos, essa tendência que pôde ser observada nas imagens de MEV.

Os ângulos de contato, aferidos entre membrana e água exibiram valores coerentes com que já foi relatado na literatura para PEI, confirmando a natureza hidrofóbica das membranas.

Foi possível constatar, em relação às propriedades de transporte, que as membranas que apresentaram melhores resultados de permeação ao vapor de água foram as amostras PEI 3 e PEI 4, enquanto PEI 5 e PEI 7 apresentaram os mais baixos valores. Este resultado é devido às características morfológicas dessas membranas, pois, PEI 3 e PEI 4 foram as membranas que apresentaram mais finas camadas superficiais e bases abundantemente macroporosas de todas as amostras, o que colabora para maior taxa de difusão das moléculas de água (v). Nas membranas PEI 5 e PEI 7, a matriz microporosa é predominante e a presença de macroporos ocorre em pequena extensão, dificultando a permeação de moléculas, e atuando com uma barreira física ao transporte difusional de massa.

Como esperado, a membrana PEI 3 apresentou baixo valor para o fator de separação ao par gasoso $\mathrm{O}_{2} / \mathrm{CO}_{2}$ enquanto as membranas PEI 5 e PEI 6, apresentaram melhores resultados, corroborando o que já foi demonstrado em trabalhos publicados: membranas com camadas microporosas mais espessas com poucos macroporos tendem a serem mais seletivas. A análise estatística também mostrou que há sinergia entre as variáveis empregadas na etapa de produção das membranas, mostrando que a melhor condição de produção de membranas permeáveis é a combinação de maior espessura úmida de membrana e menor concentração de solução polimérica. Já para obtenção de membranas mais seletivas a melhor condição é a combinação 
de menor espessura úmida de membrana e maior concentração de solução polimérica. Foi possível concluir, a partir do estudo sistemático da etapa de produção das membranas, que não é possível obter membrana com ambas as propriedades: permeabilidade e seletividade, somente através da manipulação da morfologia. Além de ter sido possível concluir que nenhuma das membranas foi mais permeável para $\mathrm{O}_{2}$ em relação ao $\mathrm{CO}_{2}$, que era um dos objetivos. Por este motivo foi pensada uma segunda etapa para este trabalho, uma modificação na superfície das membranas, visando melhorar a permeabilidade das membranas ao $\mathrm{O}_{2}$ e alcançar a propriedade de seletividade $\mathrm{O}_{2} / \mathrm{CO}_{2}$.

A membrana PEI 3 foi escolhida para a segunda etapa deste trabalho, pois como a finalidade foi verificar se a realização de modificação superficial causaria impacto na seletividade à permeação dos gases, a escolha mais coerente seria testar uma amostra que possuísse satisfatória taxa de permeação e baixo valor de fator de separação $\mathrm{O}_{2} / \mathrm{CO}_{2}$. 


\section{Capítulo II - Modificação superficial de membranas à base de poliéterimida.}

\section{Introdução}

\subsection{Modificação superficial bioinspirada}

As modificações superficiais são realizadas com o intuito de agregar, ao material de interesse, propriedades não intrínsecas. O recobrimento superficial por polidopa e por polidopamina (PDA) tem sido apontado como uma técnica de modificação superficial que traz menos prejuízos a estrutura dos materiais, comparados a outros tipos de técnicas; e aprimora propriedades hidrofílicas em materiais originalmente considerados hidrofóbicos (XU et al., 2018). Materiais modificados superficialmente por PDA apresentaram melhora na ação antifouling, na habilidade de trocas iônicas e nas propriedades de adesão (J. LI et al., 2018; XI et al., 2009).

A técnica de recobrimento de superfícies bioinspirada originou-se da habilidade dos mexilhões (Mytilus Edulis) aderirem às superfícies de rochas marinhas e embarcações, mesmo em ambientes úmidos. Os mexilhões produzem e secretam uma substância que ficou conhecida por "cola biológica", em razão de sua enorme resistência às forças de turbulência das águas marinhas e impermeabilidade.

Estudos demonstraram que, dentre outros componentes, foi detectada alta incidência da catecolamina 3,4-dihidroxi-L-fenilalanina (DOPA), e do aminoácido lisina na referida substância (SILVERMAN; ROBERTO, 2007). Atribui-se a DOPA, Figura 13a, as propriedades adesivas da substância secretada pelo mexilhões (LEE; LEE; MESSERSMITH, 2007; YU; HWANG; DEMING, 1999), um dos motivos é a sua capacidade de complexar íons metálicos e óxidos, o que explica a boa adesão às rochas marinhas (SILVERMAN; ROBERTO, 2007). Em adição, participa de reações intermoleculares, as quais são responsáveis por formar a "cola biológica" e possui a capacidade de interagir fortemente, por interações covalente e não covalentes, com materiais variados; orgânicos, inorgânicos e semimetais (LEE, 2012; LEE; SCHERER; MESSERSMITH, 2006). 
Figura13. Representação das moléculas de DOPA e dopamina.<smiles>N[C](Cc1ccc(O)c(O)c1)C(=O)O</smiles>

a. L-DOPA<smiles>NCCc1ccc(O)c(O)c1</smiles>

b. Dopamina

Fonte: (Química Nova Interativa, 2020) ADAPTADO

Considerando a hipótese de que a propriedade de adesão e de "cura" intermolecular é atribuída a presença dos grupos catecol e amina, a dopamina, Figura 13b, que possui ambos os grupos funcionais, foi apontada como uma substância equivalente para, através de rota sintética, obter material similar à substância secretada pelos mexilhões, apoiada na sua característica de auto polimerização. (BURZIO; WAITE, 2000; LEE, 2012). Um esquema do provável mecanismo de reação base de auto polimerização de moléculas de DOPA, assim como ocorre para dopamina, está ilustrado na Figura 14.

Figura14. Representação esquemática da autopolimerização de moléculas de DOPA.

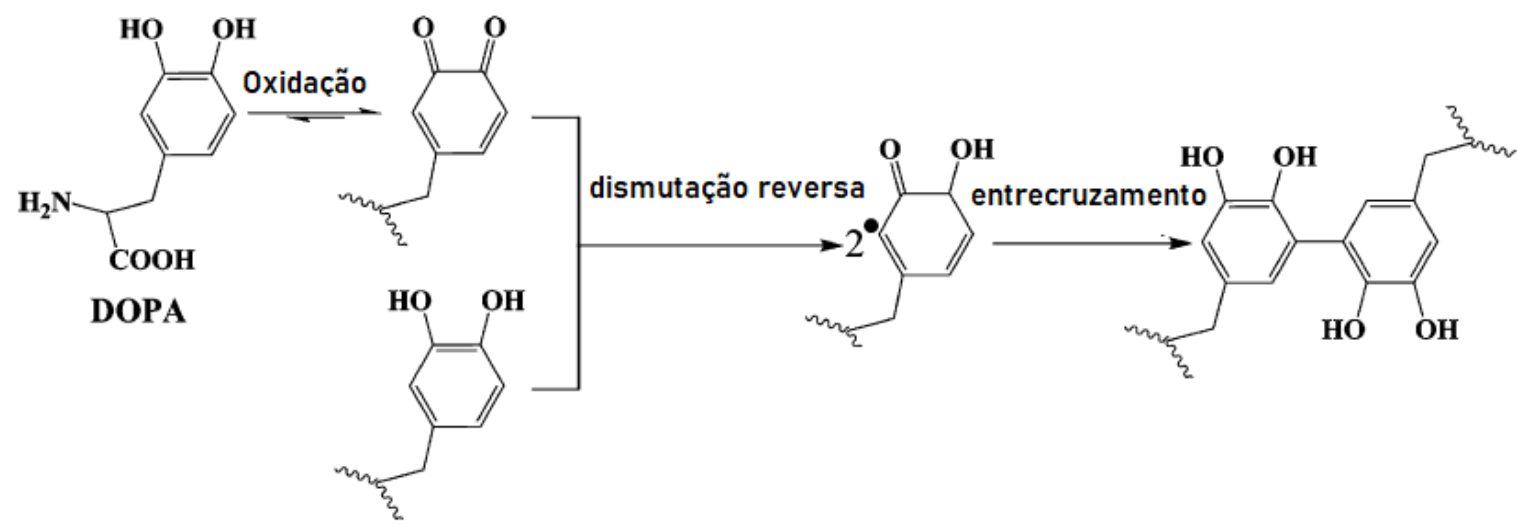

*Aplica-se a moléculas de dopamina.

Fonte: ADAPTADO (Xi et al., 2009) 
A dopamina sofre processo de auto polimerização em ambiente com características similares ao ambiente marinho, levemente alcalino, e como resultado, é formada uma substância polimérica que adere fortemente a superfícies de materiais variados. O processo de auto polimerização para DOPA/dopamina não é conhecido por completo, mas há um consenso de que seja complexo e envolva interações covalente e não covalentes, em razão da abundante disponibilidade de grupos funcionais: amina, hidroxi-fenol (catecol) e carbonila (proveniente de o-quinonas) (LEE; SCHERER; MESSERSMITH, 2006; WANG et al., 2016; YU; HWANG; DEMING, 1999).

Em razão de se formar um polímero funcionalizado, este, confere às superfícies nas quais se deposita, características hidrofílicas, maior capacidade de trocas iônicas, além de ser reconhecido como uma plataforma versátil para ocorrência de reações químicas, propiciando, por exemplo, a construção de uma segunda camada de recobrimento superficial. 


\section{Objetivos}

\subsection{Objetivo geral}

Realizar modificação bioinspirada na superfície de membranas do tipo PEI 3, obtidas na etapa anterior deste trabalho, a fim de aprimorar sua propriedade de transporte: seletividade $\mathrm{O}_{2} / \mathrm{CO}_{2}$.

\subsection{Objetivos específicos}

- Realizar modificação bioinspirada, recobrimento com polidopamina, em membranas PEI 3 , a fim de promover a funcionalização de suas superfícies, de acordo com os protocolos já estabelecidos na literatura;

- Comprovar a ocorrência da etapa de modificação através das caracterizações: a) termogravimetria e $b$ ) FTIR - ATR;

- Analisar o impacto da modificação nas propriedades morfológicas da superfície das membranas através de medidas de ângulo de contato, de energia livre superficial e energia livre de interação; análise de imagens digitais e microgafias eletrônicas;

- Caracterizar as membranas modificadas em relação às suas propriedades de transporte, permeação ao vapor de água e seletividade ao par gasoso $\mathrm{O}_{2} / \mathrm{CO}_{2}$ e avaliar os resultados comparativamente a membranas não modificadas. 


\section{Metodologia Experimental}

\subsection{Materiais}

Na etapa de modificação bioinspirada foram empregados os seguintes reagentes:

- Cloridrato de dopamina (CAS - 62-31-7)

- Tris(hidroximetil)aminometano (CAS - 77-86-1)

- Ácido Clorídrico (CAS - 7647-01-0)

\subsection{Procedimento da modificação bioinspirada}

Para alcançar o ambiente necessário à auto polimerização da dopamina, uma solução tampão Tris - $\mathrm{HCl}$ 0,01 M (pH = 8,0), similar às condições do ambiente marinho, foi utilizada para dissolver 1,0 g de cloridrato de dopamina, (JIANG et al., 2010; XI et al., 2009). Em um recipiente de vidro, uma membrana por vez, foi depositada e coberta com solução Tris dopamina, e a este conjunto foi aplicada agitação magnética moderada, onde ficaram por períodos de 3, 6 e 9 horas. As membranas poliméricas funcionaram como um substrato, onde a polidopamina se depositou. Foi possível observar visualmente a evidência da ocorrência do processo de auto polimerização, pois ocorre mudança da coloração da solução de amarelo acastanhado para marrom intenso. Após o período de modificação, as membranas foram mergulhadas em água destilada durante 24 horas, e secas em estufa a $60{ }^{\circ} \mathrm{C}$ por 8 horas.

Foram submetidas a este procedimento apenas membranas do tipo PEI 3, Tabela 2, conforme apontamentos das conclusões do capítulo anterior. Na Tabela 8 encontram-se especificadas as amostras produzidas nesta etapa no trabalho.

Tabela 8. Amostra produzidas por modificação bioinspirada

\begin{tabular}{ccc}
\hline \hline Amostra & Tipo de membrana & Período de modificação \\
\hline DOPA 3 & PEI 3 & 3 horas \\
DOPA 6 & PEI 3 & 6 horas \\
DOPA 9 & PEI 3 & 9 horas \\
\hline \hline
\end{tabular}

As membranas foram modificadas por períodos diferentes, para que pudesse ser realizado um estudo comparativo. 


\subsection{Caracterização das membranas modificadas}

\subsubsection{Espectroscopia na região do infravermelho com transformada de Fourier e acessório de refletância total atenuada - IVTF RTA}

A membrana PEI 3 e as membranas modificadas DOPA 3, 6 e 9 foram caracterizadas através de espectroscopia na região do infravermelho com a finalidade de verificar possíveis interações entre PEI e polidopamina que comprovasse a modificação superficial bioinspirada. Devido à natureza física das membranas a análise foi realizada com o auxílio de um acessório de refletância total atenuada (ATR) baseado em cristal de seleneto de zinco (ZnS). As membranas foram recortadas nos moldes do porta-amostra do equipamento, onde foram depositadas de modo a garantir o contado entre a superfície da amostra e o cristal.

O cloreto de dopamina também foi analisado, com a finalidade de comparação, seu espectro foi obtido na forma de pastilha de $\mathrm{KBr}$. A obtenção da amostra para análise ocorre nas seguintes etapas: a) mistura do cloreto de dopamina a brometo de potássio ( $\mathrm{KBr}$, grau espectroscópico) na proporção de 1:100 $(\mathrm{g}) ; b$ ) prensagem, em prensa manual Carver Laboratory Press - modelo 3648, para obtenção da pastilha.

As análises de espectroscopia foram realizadas em um equipamento FTIR Agilent 3200, com acúmulo de 32 varreduras, resolução de $4 \mathrm{~cm}^{-1}$, no intervalo de $4000-600 \mathrm{~cm}^{-1}$, à temperatura ambiente.

\subsubsection{Análise termogravimétrica}

A membrana PEI 3 e as membranas modificadas DOPA 3, 6 e 9 foram caracterizadas através de análises termogravimétricas, a fim de obter as informações: $a$ ) estabilidade térmica das membranas, através da determinação da temperatura onset dos eventos térmicos associados à decomposição da amostra; $b$ ) temperatura de máxima decomposição, determinada pelo máximo da primeira derivada da curva de perda de massa em função da temperatura. As análises foram realizadas em um equipamento TGA Netzsch Tarsus F3 onde foram utilizados cadinhos de alumina como porta amostra e aproximadamente $10 \mathrm{mg}$ de amostra. A dinâmica de análise compreendeu uma rampa de aquecimento de $25^{\circ} \mathrm{C}$ até $800{ }^{\circ} \mathrm{C}$ à taxa de $20^{\circ} \mathrm{C} \mathrm{min}^{-1}$, sob fluxo

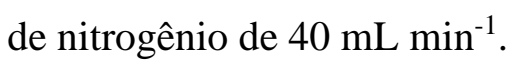




\subsubsection{Medidas de ângulo de contato, energia livre de superfície e energia livre de interação $\underline{(\Delta \mathrm{G})}$}

Medidas do ângulo de contato entre membranas de PEI não modificadas e modificadas e os seguintes líquidos de prova: $a$ ) água destilada; $b$ ) di-iodometano; $c$ ) etilenoglicol, foram obtidas com a finalidade de se analisar, comparativamente, suas características morfológicas, e obter sua energias livre de interação e superfície.

Tiras retangulares (aproximadamente $5 \mathrm{~cm} \times 1 \mathrm{~cm}$ ) das membranas foram fixadas no porta-amostra do equipamento, e na sequência, com o auxílio de uma microsseringa, gotas (aproximadamente 2,0 $\mu \mathrm{L}$ ) dos líquidos de prova foram depositadas sobre as amostras. A análise foi executada em modo estático, ou seja, a amostra permaneceu fixa, e a cada gota depositada, os ângulos de contato foram medidos por um período de 60 segundos. $\mathrm{O}$ equipamento utilizado foi um goniômetro da marca Ramé-Hart modelo 260, que mediu e registrou, em triplicata, os ângulos de contato de ambos os lados de cada gota. Foram realizadas medidas de 3 gotas em diferentes pontos para cada tira de amostra, assim, os valores finais de ângulo de contato correspondem à média das determinações. Esta caracterização foi realizada conforme protocolo ASTM D5725 (ASTM - American Society for Testing and Materials, 1999).

A partir dos valores de ângulo de contato e dos valores tabelados de tensão superficial dos líquidos de prova $\left(\Upsilon_{\mathrm{L}}{ }^{\mathrm{LW}}, \Upsilon_{\mathrm{L}}^{+}, \Upsilon_{\mathrm{L}}^{-}\right)$foram determinados os valores de energia livre de superfície $\left(\Upsilon^{\text {total }}\right)$ e de seus componentes apolar $\left(\Upsilon^{\mathrm{LW}}\right)$ e polar $\left(\Upsilon^{\mathrm{AB}}\right)$, elétron doador $\left(\Upsilon^{-}\right)$e elétron receptor $\left(\Upsilon^{+}\right)$, a partir do emprego da equação de Young na forma da Equação 16, de acordo com o proposto por van Oss et al (CAREL J. van OSS; CHAUDHURY; GOOD, 1988), onde os subscritos "L" e "S", nas equações a seguir, denotam as fases líquida e sólida dos materiais.

$$
(1+\cos \theta) \gamma_{L}=2\left(\sqrt{\gamma_{S}^{L W} \gamma_{L}^{L W}}+\sqrt{\gamma_{S}^{+} \gamma_{L}^{-}}+\sqrt{\gamma_{S}^{-} \gamma_{L}^{+}}\right)
$$


De acordo com van Oss et al. a energia de superfície total é calculada pela soma das componentes apolar e polar, Equação 17.

$$
\gamma^{\text {Total }}=\gamma^{L W}+\gamma^{A B} \quad \text { Equação } 17
$$

Sendo o componente apolar calculado a partir da Equação 18:

$$
\gamma_{L}(1+\cos \theta)=2\left(\sqrt{\gamma_{S}^{L W} \gamma_{L}^{L W}}\right) \quad \text { Equação } 18
$$

E o componente polar calculado a partir da equação 19:

$$
\gamma_{S L}^{A B}=-2\left(\sqrt{\gamma_{S}^{+} \gamma_{L}^{-}}+\sqrt{\gamma_{S}^{-} \gamma_{L}^{+}}\right) \quad \text { Equação } 19
$$

O cálculo da energia livre de interação $(\Delta G)$ foi realizado a partir dos valores das componentes de energia obtidos para as membranas e de parâmetros de tensão superficial de água destilada, Equação 20 (C. J. van OSS, 1995), e possibilitou a avaliação da hidrofobicidade das membranas modificadas e não modificadas.

$$
\Delta G_{S L}=-2 \gamma_{S L} \quad \text { Equação } 20
$$

Os cálculos dos componentes apolar $\left(\Upsilon^{\mathrm{LW}}\right)$ e polar $\left(\Upsilon^{\mathrm{AB}}\right)$, elétron doador $\left(\Upsilon^{-}\right)$e elétron receptor $\left(\Upsilon^{+}\right)$e da energia livre de interação $(\Delta G)$ foram efetuados a partir do emprego de planilha elaborada com as equações supracitadas, através do software Excel, Office 2016. 


\subsubsection{Ensaios de transporte}

Análises de TVA e Permeação aos gases $\mathrm{O}_{2}$ e $\mathrm{CO}_{2}$ foram realizadas para as membranas PEI 3, DOPA 3, DOPA 6 e DOPA 9, seguindo os métodos descritos anteriormente, nas seções 3.3.3.1 e 3.3.3.2.

\section{Resultados e Discussão}

\subsection{Modificação bioinspirada}

As membranas modificadas através do procedimento de recobrimento por polidopamina foram fotografadas com a finalidade de identificação visual através da alteração da coloração de suas superfícies. Na Figura 15 as imagens digitais estão compiladas.

Figura15. Imagens digitais de membranas de PEI modificadas e não modificada
A. PEI 3
B. DOPA 3
C. DOPA 6
D. DOPA 9
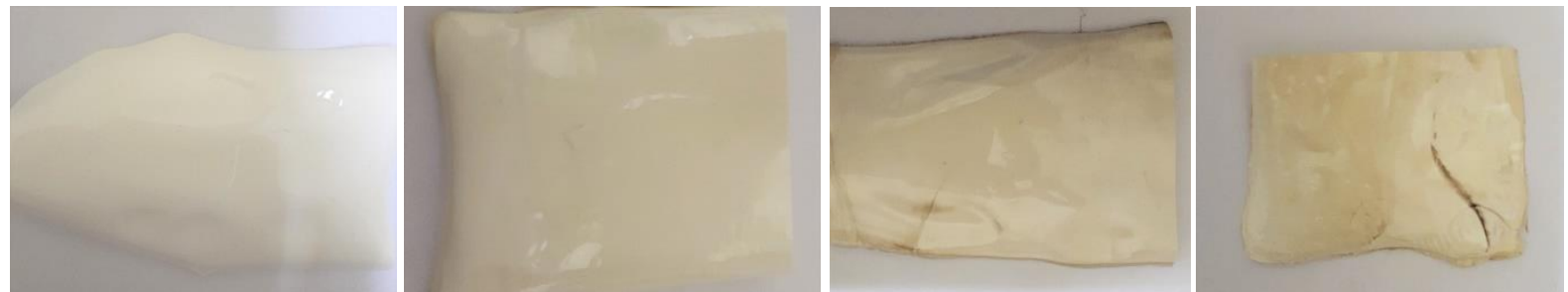

Fonte: Autoria própria

Pode-se observar nas imagens mudança gradual na coloração das membranas. A membrana a base de PEI não modificada se caracteriza pela cor branca, as membranas modificadas, DOPA 3, 6 e 9, se caracterizam pela coloração marrom, que apresentaram gradiente de coloração em razão dos diferentes períodos de modificação a que foram submetidas. Para corroborar a comprovação da etapa de modificação das membranas, caracterizações específicas foram realizadas e seus resultados são apresentados na sequência. 
9.2 Espectroscopia na região do infravermelho com transformada de Fourier e acessório de refletância total atenuada - IVTF RTA

No espectro de IVTF da Figura 16, e na Tabela 9, estão as atribuições das bandas de absorção características da dopamina verificadas neste trabalho e na literatura (DREYER et al., 2012; LAGUTSCHENKOV et al., 2011; LÓPEZ et al., 2011).

Figura16. Espectro de IVTF obtido para cloreto de dopamina

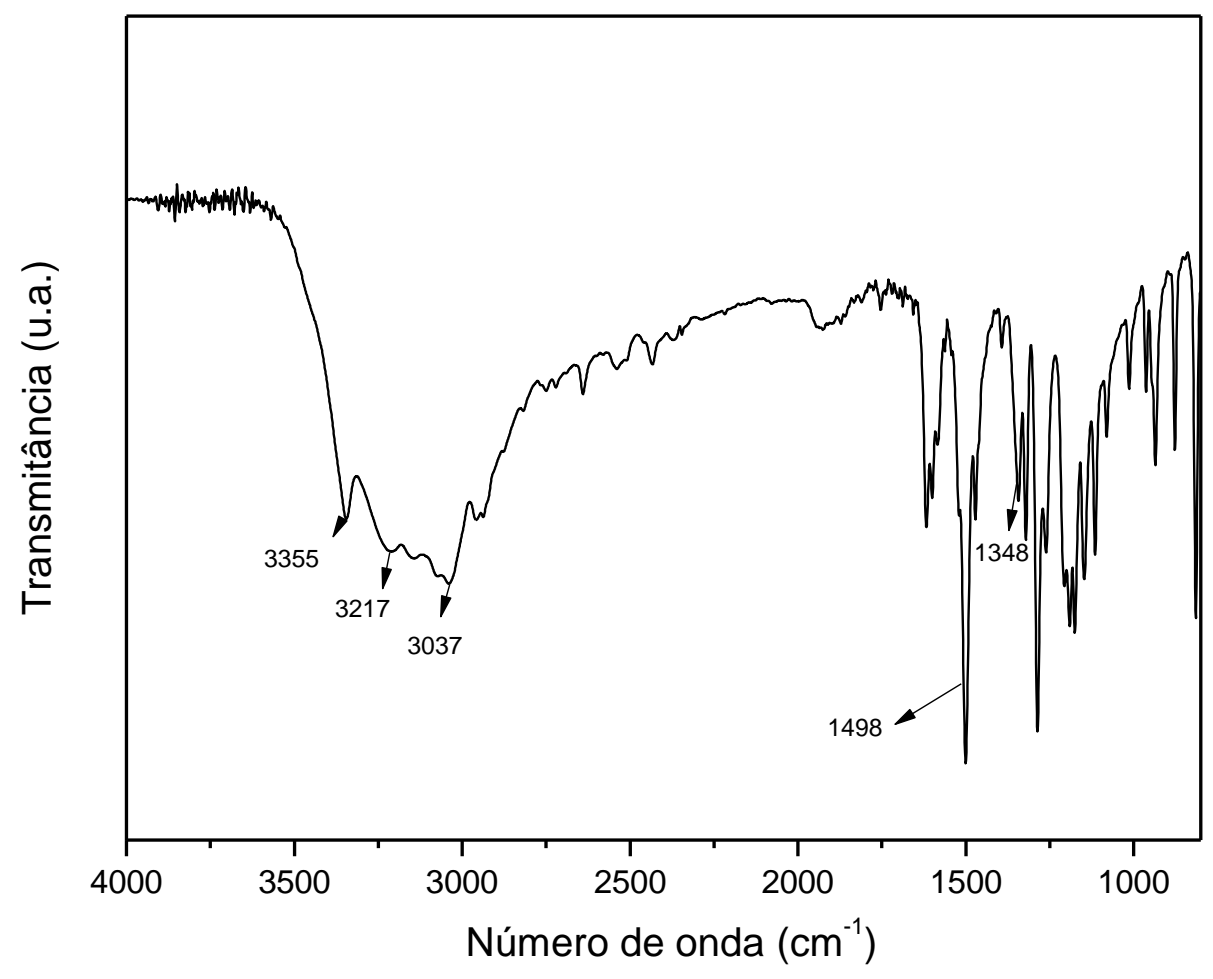

Fonte: Autoria própria

Segundo López et al. (2011) podem ser observadas três importantes bandas de absorção, na região de baixa energia, em $3350 \mathrm{~cm}^{-1}$ correspondente à deformação axial de ligação $\mathrm{O}-\mathrm{H}$, em $3205 \mathrm{~cm}^{-1}$ correspondente à deformação axial de ligação $\mathrm{C}-\mathrm{N}$ e em $3034 \mathrm{~cm}^{-1}$ correspondente à deformação axial de ligação $\mathrm{N}-\mathrm{H}$, ligações características dos grupos presentes na estrutura da dopamina. O mesmo ocorreu para as importantes bandas de absorção na região de alta energia, segundo López et al. (2011) e Lagutschenkov et al. (2011), em $1494 \mathrm{~cm}^{-1}$ ocorre banda de absorção devida à deformação angular de ligação $\mathrm{C}-\mathrm{H}$, e em 
$1342 \mathrm{~cm}^{-1}$ ocorre banda de absorção devida à deformação angular dentro do plano de ligação $\mathrm{O}-\mathrm{H}$, características de grupos funcionais hidroxilas presentes na estrutura da dopamina. Podese observar no espectro de IVTF, obtido neste trabalho, que foram identificadas bandas em valores de número de onda $\left(\mathrm{cm}^{-1}\right)$ muito próximos aos reportados na literatura.

Tabela 9. Principais atribuições de bandas de absorção no IV para cloreto de dopamina

\begin{tabular}{ccc}
\hline Atribuições & \multicolumn{2}{c}{ Banda de absorção (cm-1) } \\
\cline { 2 - 3 } Deformação axial de $\mathbf{O}-\mathbf{H}$ & Literatura* & Presente trabalho \\
\cline { 2 - 3 } Deformação axial de C-N & 3350 & 3355 \\
Deformação axial de N-H & 3205 & 3217 \\
Deformação angular de C-H & 3034 & 3037 \\
Deformação angular de O-H no plano & 1494 & 1348 \\
\hline
\end{tabular}

* López et al. (2011); Lagutschenkov et al. (2011).

De acordo com Amancio-Filho et al. (2008) as principais bandas de absorção características de PEI na região do infravermelho (IV) são: a) em $3060 \mathrm{~cm}^{-1}$ devida à deformação axial de ligação $\mathrm{C}-\mathrm{H}$ em anel aromático, $b$ ) em $1777 \mathrm{~cm}^{-1}$ devida à deformação axial de ligação $\mathrm{C}=\mathrm{O}$ em anel imida, $c$ ) em $1348 \mathrm{~cm}^{-1}$ devida à deformação axial de ligação $\mathrm{C}$ $\mathrm{N}$ em anel ftalamida, $d$ ) na faixa $1013-1262 \mathrm{~cm}^{-1}$ devida à deformação axial de ligação Ar-OAr. No espectro obtido para a membrana PEI 3, Figura 17 , observa-se que foram identificadas bandas de valores muito próximos aos supracitados. 
Figura17. Espectro IVTF obtido para membrana de PEI

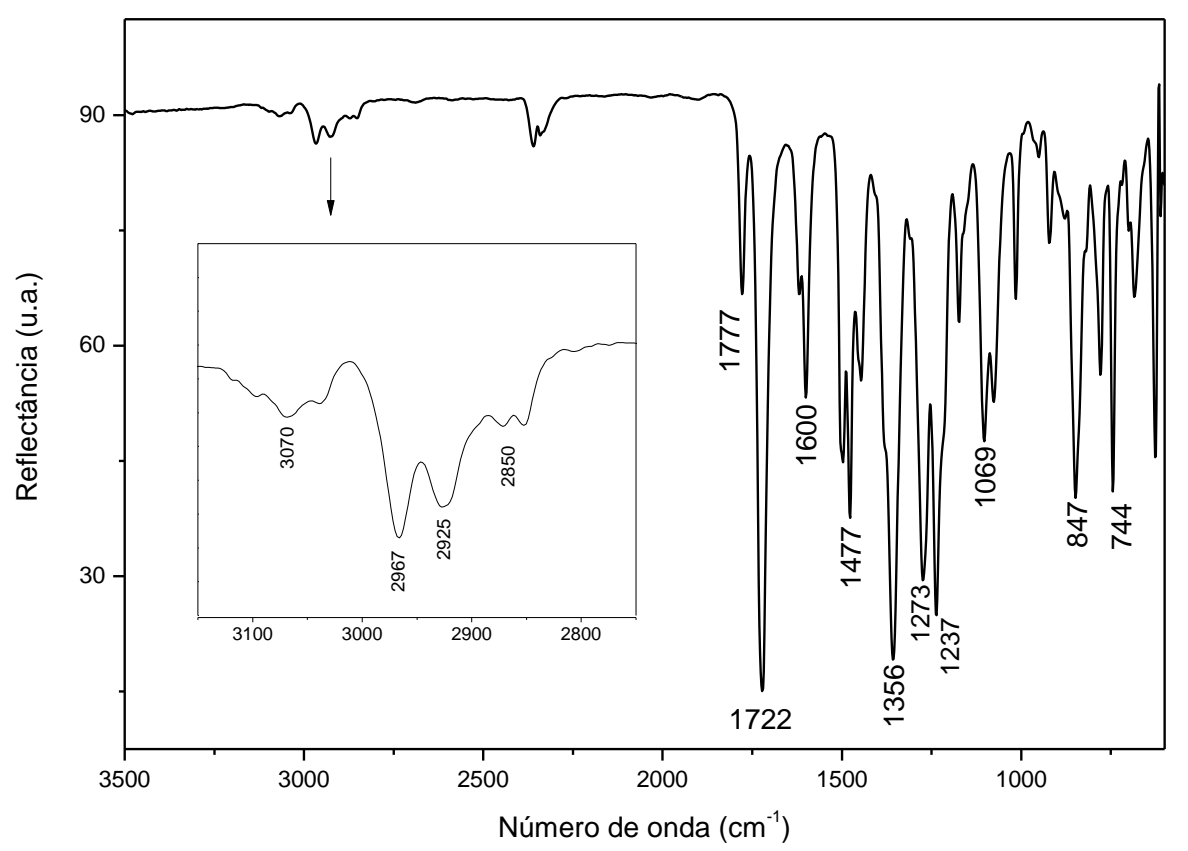

Fonte: Autoria própria

Na Tabela 10 estão as atribuições as bandas de absorção características de PEI verificadas neste trabalho e na literatura (AMANCIO-FILHO et al., 2008). 
Tabela 10. Principais atribuições de bandas de absorção no IV obtidas para membrana de PEI

\begin{tabular}{|c|c|c|}
\hline \multirow[t]{2}{*}{ Atribuições } & \multicolumn{2}{|c|}{ Banda de absorção $\left(\mathrm{cm}^{-1}\right)$} \\
\hline & $\begin{array}{l}\text { Amancio- } \\
\text { Filho et al. }\end{array}$ & Presente trabalho \\
\hline $\begin{array}{c}\text { Deformação axial simétrica }(\mathrm{C}-\mathrm{H}) \text { no } \\
\text { anel } \\
\text { aromático }\end{array}$ & 3060 & 3070 \\
\hline $\begin{array}{l}\text { Deformação axial simétrica alifática (C- } \\
\qquad \mathrm{H})\end{array}$ & $\begin{array}{c}2970,2930, \\
2875\end{array}$ & $2967,2925,2850$ \\
\hline $\begin{array}{l}\text { Deformações axiais assimétricas e } \\
\text { simétricas }(C=O) \text { de anéis imida }\end{array}$ & 1777,1715 & 1777,1722 \\
\hline Deformação axial $(C-N)$ ou $(C=C)$ & 1598 & 1600 \\
\hline Deformação axial no anel aromático & 1476 & 1477 \\
\hline $\begin{array}{c}\text { Deformação axial (C-N) no anel de } \\
\text { ftalimida }\end{array}$ & 1348 & 1356 \\
\hline Deformação axial (Ar-O-Ar) & $\begin{array}{l}1262,1232 \\
1070,1013\end{array}$ & $1273,1237,1069$ \\
\hline $\begin{array}{c}\text { Deformação vibracional do anel } \\
\text { aromático }\end{array}$ & 833 & 847 \\
\hline Deformação angular do anel ftalimida & 740 & 744 \\
\hline
\end{tabular}

Foi possível identificar, através dos experimentos e do levantamento bibliográfico, as estruturas de PEI e dopamina, ambos materiais de partida na etapa de modificação das membranas.

Espectros de IVTF das membranas modificadas, Figura18, também foram obtidos, e comparados com os espectros dos materiais de partida, com a finalidade de comprovar a deposição de polidopamina sobre as membranas de PEI. 
Figura18. Espectros obtidos para a série de membranas de PEI modificadas, para a membrana de PEI não modificada e para cloreto de dopamina.

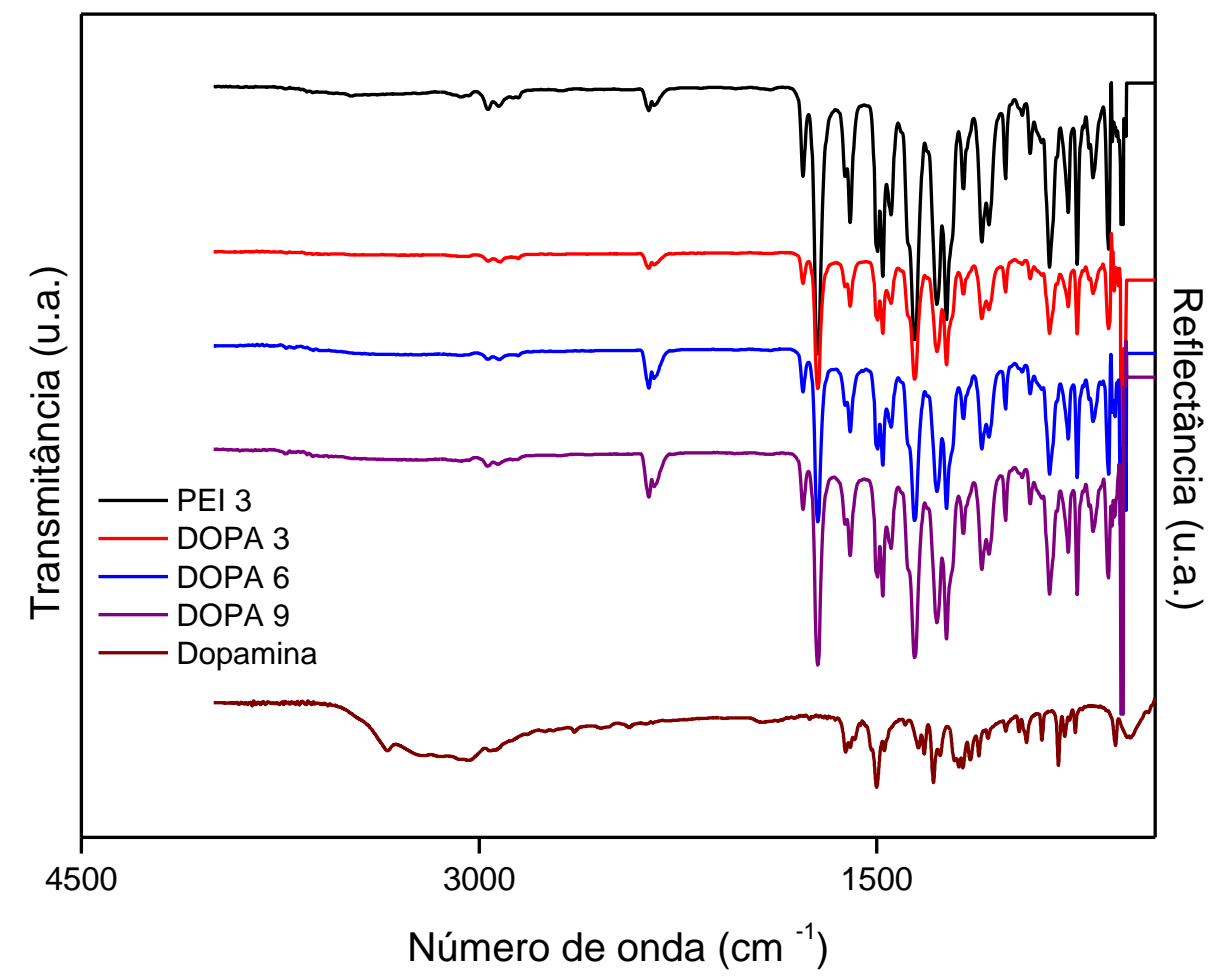

Fonte: Autoria própria

Nota-se pelos espectros das membranas modificadas, apresentados na Figura 18, que as bandas de absorção características de PEI também foram verificadas para as amostras DOPA 3, 6 e 9. Bandas de possível ocorrência na região de alta energia, características de grupos presentes na dopamina, provavelmente foram encobertas pelas bandas características de PEI, e as bandas características da região de baixa energia, referentes a dopamina, não foram identificadas nos espectros das membranas modificadas. Tão pouco, para estes espectros, foram identificadas diferentes bandas com atribuições que pudessem sugerir a presença de novas ligações, indicando interações entre dopamina e PEI. Assim, concluiu-se que a técnica IVTF não foi suficiente para comprovar a modificação superficial das membranas de PEI.

$\mathrm{Na}$ intenção de concretizar esta etapa do trabalho de comprovar a modificação superficial, análises termogravimétricas e medidas de ângulo de contato, energia de superfície e energia livre de interação foram realizadas. 


\subsection{Análises termogravimétricas}

A técnica de análise termogravimétrica foi empregada para avaliar as estabilidades térmicas da membrana PEI 3, amostra não modificada, e membranas DOPA 3, DOPA 6 e DOPA 9, amostras modificadas por períodos diferentes, a fim de comprovar a presença de polidopamina nas membranas modificadas. Na Figura 19 estão as curvas termogravimétricas de todas as amostras, observa-se que houve variação da estabilidade térmica da amostra PEI 3 para a amostra DOPA 9, em ordem crescente de temperatura. Observam-se também os valores de resíduos, próximo a $800{ }^{\circ} \mathrm{C}$, na faixa de 45 a $55 \%$.

Figura19. Curvas termogravimétricas obtidas para a série de membranas de PEI modificadas e não modificada.

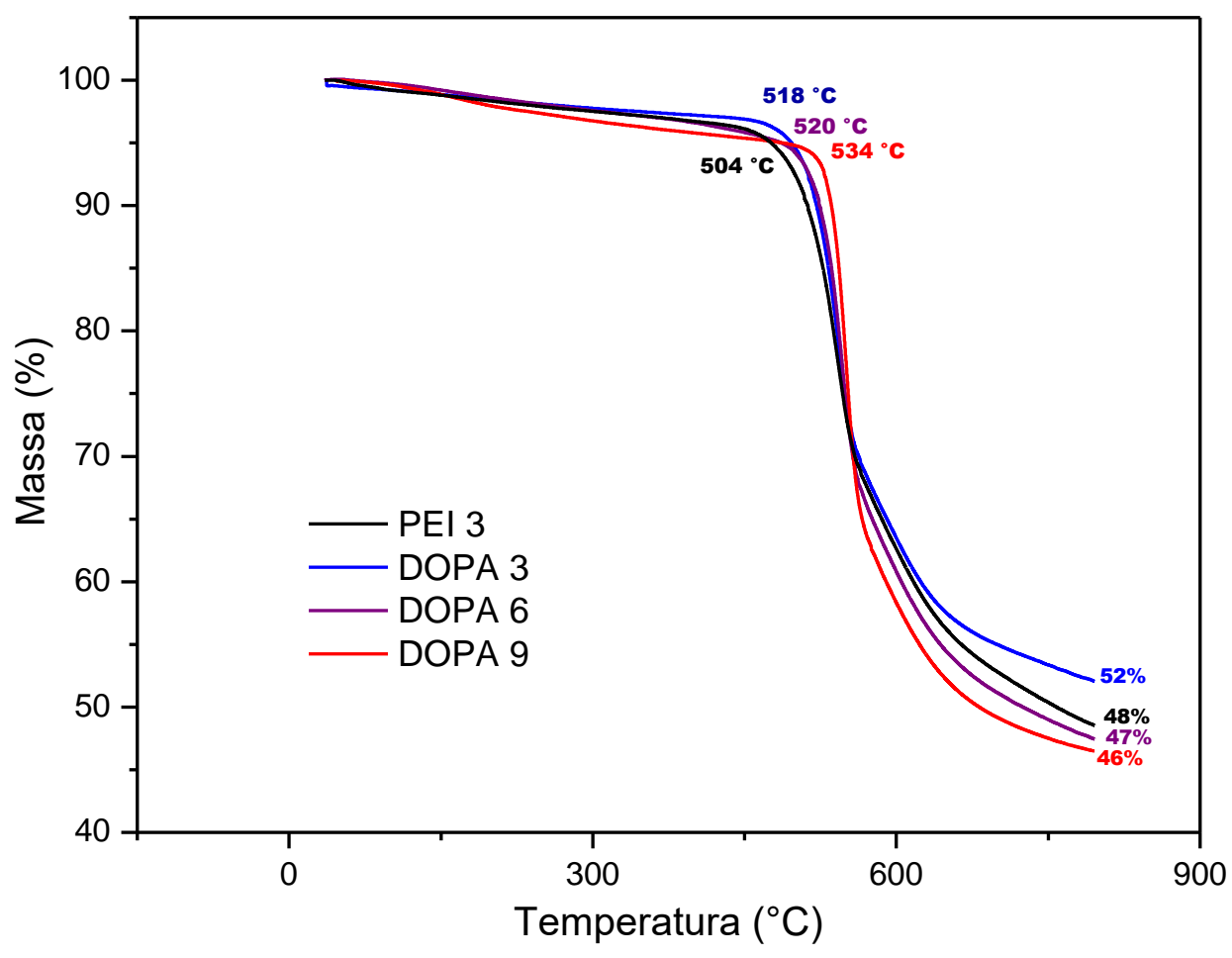

Fonte: Autoria própria

De acordo com CARROCIO et al (CARROCCIO; PUGLISI; MONTAUDO, 2000) é característico do PEI ter o início de sua primeira degradação térmica em aproximadamente $450{ }^{\circ} \mathrm{C}$ e apresentar máximo de degradação nos arredores de $510{ }^{\circ} \mathrm{C}$. O segundo evento de degradação ocorre em $600{ }^{\circ} \mathrm{C}$, e produz massa residual em torno de $60 \%$, em $800{ }^{\circ} \mathrm{C}$. Na 
comparação entre PEI 3 e amostras DOPA 3, 6 e 9, nota-se a tendência de aumento na estabilidade térmica. A partir deste resultado pode-se sugerir que mais energia tenha sido necessária para desfazer prováveis interações que se estabeleceram entre PEI e polidopamina, durante o processo de auto polimerização e deposição. Em decorrência, as temperaturas onset da primeira degradação das membranas modificadas se alteraram. Pode-se observar também, pela primeira derivada das curvas termogravimétricas (que a temperatura máxima de decomposição segue a mesma tendência supracitada, aumento da temperatura de PEI 3 para DOPA 9, o que indica a possibilidade de deposição de maior quantidade de dopamina em consequência de maior tempo de exposição das membranas à solução de auto polimerização Figura 20.

Figura20. Curvas termogravimétricas derivadas obtidas para a série de membranas de PEI modificadas e não modificada.

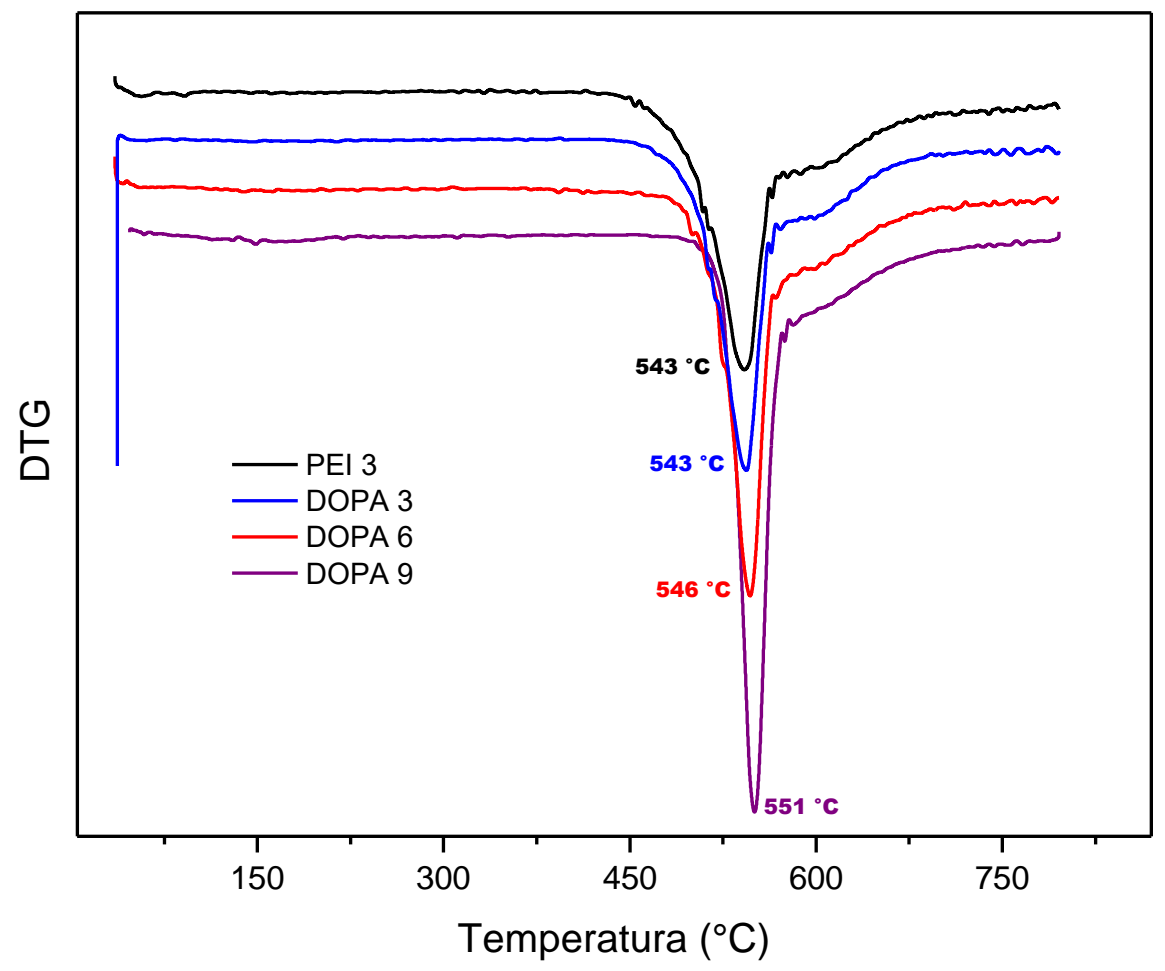

Fonte: Autoria própria 
Este resultado indica que é necessária maior energia para a ocorrência do início dos eventos térmicos, assim como o evento de máxima degradação térmica nas membranas que possuem recobrimento de polidopamina do que em membranas não recobertas.

De acordo com THAKUR (THAKUR, 2012), a dopamina possui importante evento de degradação térmica na faixa de temperatura $300-500{ }^{\circ} \mathrm{C}$, atribuído a quebra de ligações em grupos alquilas e ligações de grupos amida, que corroboram as conclusões indicadas.

\section{4 Ângulo de contato, energia de superfície e energia livre de superfície}

Medidas de ângulo de contato entre as membranas de PEI não modificadas e modificadas e três líquidos de prova com diferentes propriedades foram obtidas e estão compiladas na Tabela 11.

Tabela 11. Valores de ângulo de contato obtidos para a série de membranas de PEI modificadas e não modificada a partir de diferentes líquidos de prova.

\begin{tabular}{cccc}
\hline \hline Amostra & Água $\left(^{\circ}\right)$ & Etilenoglicol $\left(^{\circ}\right)$ & Di-iodometano $\left(^{\circ}\right)$ \\
\hline \hline PEI 3 & $78 \pm 5$ & $57 \pm 2$ & $34 \pm 3$ \\
DOPA 3 & $66 \pm 2$ & $42 \pm 4$ & $33 \pm 4$ \\
DOPA 6 & $63 \pm 3$ & $35 \pm 2$ & $32 \pm 5$ \\
DOPA 9 & $55 \pm 3$ & $45 \pm 3$ & $30 \pm 5$ \\
\hline \hline
\end{tabular}

Pode ser observado que os valores de ângulo de contato medidos a partir de água e etilenoglicol apresentaram a tendência de diminuição na comparação entre membranas não modificada e modificadas. Na comparação entre as membranas modificadas por diferentes períodos (DOPA 3, 6 e 9) é possível notar tendência de diminuição dos valores, progressivamente, DOPA 3 a 9, para valores obtidos a partir da água. Para os valores obtidos a partir de etilenoglicol, nota-se que a membrana DOPA 6 apresentou menor valor médio em relação as outras membranas, que apresentaram valores muito próximos, principalmente quando são considerados os desvios. É possível sugerir, em relação a DOPA 6, que tenha havido alguma interferência, alheia às propriedades químicas da superfície desta membrana, que proporcionou a obtenção de tal resultado, como a topografia. Para as medidas obtidas a partir 
do di-iodometano, líquido apolar, pode-se observar que não houve alteração significativa nos valores, considerando os desvios, para todas as membranas.

Esta análise permite sugerir, preliminarmente, que houve modificação superficial das membranas, por recobrimento com polidopamina, corroborando as conclusões das análises termogravimétricas, que permite que líquidos polares se espalhem mais nas suas superfícies que nas superfícies de membranas não modificadas, o que indica um possível aumento das interações polares.

Pelos dados da Tabela 12 pode-se observar que a componente dispersiva tem maior contribuição no valor da energia de superfície que a componente polar, para todas as membranas.

Tabela 12. Valores de componente dispersiva $\left(\Upsilon^{\mathrm{LW}}\right)$, componente polar $\left(\Upsilon^{\mathrm{AB}}\right)$, elétron doador $\left(\Upsilon^{-}\right.$ ), elétron receptor $\left(\Upsilon^{+}\right)$, energia livre de superfície $\left(\Upsilon^{\text {total }}\right)$ e energia livre de interação $(\Delta G)$, em $\mathbf{m J}$ $\mathbf{m}^{-2}$ obtidos para a série de membranas de PEI modificadas e não modificada.

\begin{tabular}{ccccccc}
\hline \hline Amostra & $\boldsymbol{\Upsilon}^{\mathbf{L W}}$ & $\boldsymbol{\Upsilon}^{-}$ & $\mathbf{\Upsilon}^{+}$ & $\mathbf{Y}^{\mathbf{A B}}$ & $\boldsymbol{\Upsilon}^{\text {Total }}$ & $\Delta \mathbf{G}$ \\
\hline \hline PEI 3 & $42,5 \pm 1,3$ & $0,14 \pm 0,17$ & $10,3 \pm 4,7$ & $3,04 \pm 1,42$ & $45,5 \pm 3,3$ & $-33,6 \pm 2,7$ \\
DOPA 3 & $42,7 \pm 1,9$ & $0,05 \pm 0,04$ & $15,0 \pm 2,9$ & $1,03 \pm 1,41$ & $44,7 \pm 2,9$ & $-34,1 \pm 6,2$ \\
DOPA 6 & $43,3 \pm 2,2$ & $0,16 \pm 0,06$ & $16,3 \pm 3,5$ & $3,36 \pm 0,44$ & $46,7 \pm 2,6$ & $-30,0 \pm 8,9$ \\
DOPA 9 & $44,3 \pm 2,4$ & $0,13 \pm 0,11$ & $30,0 \pm 3,2$ & $4,10 \pm 2,31$ & $48,2 \pm 6,6$ & $-1,9 \pm 3,9$ \\
\hline \hline
\end{tabular}

Não houve alteração significativa dos valores das componentes apolar e polar entre a amostra PEI 3 e as amostras DOPA 3,6 e 9, levando em consideração os valores de desvios. Verifica-se ainda a predominância do componente elétron receptor $\left(\Upsilon^{+}>\Upsilon^{-}\right)$, para todas as membranas, adicionalmente nota-se a tendência do aumento deste valor, progressivamente de PEI 3 a DOPA 9. A partir do que foi verificado sugere-se que membranas produzidas a base de PEI possuem a capacidade de participar de interações apolares e polares, sendo as apolares as predominantes. As interações polares se caracterizam receptoras de elétrons, e são aprimoradas pela presença da polidopamina, no caso das membranas de PEI modificadas.

A energia livre de interação $(\Delta G)$ das membranas de PEI, não modificadas e modificadas, com água, foi calculada a partir dos valores referentes aos componentes de energia livre de superfície, resultados que consistem na medida quantitativa de hidrofobicidade/ hidrofilicidade. Por definição (C. J. van OSS, 1995) materiais hidrofóbicos são aqueles que 
apresentam $\Delta \mathrm{G}<0$, e hidrofílicos são aquele que apresentam $\Delta \mathrm{G}>0$. Desta forma pode-se verificar que todas as membranas possuem superfícies hidrofóbicas, entretanto a membrana DOPA 9 apresentou um valor muito menos negativo em comparação a todas outras, que apresentaram valores similares, o que pode sugerir que a superfície da referida membrana, que foi a amostra modificada durante o maior período, se apresenta menos hidrofóbica.

9.5 Ensaios de transporte

Os resultados obtidos para a análise de TVA das membranas PEI 3, DOPA 3, DOPA 6 e DOPA 9 estão apresentados no diagrama de Pareto, Figura 21.

Figura21. Taxas de permeação de vapor de água obtidas para membranas de PEI não modificada e modificadas.

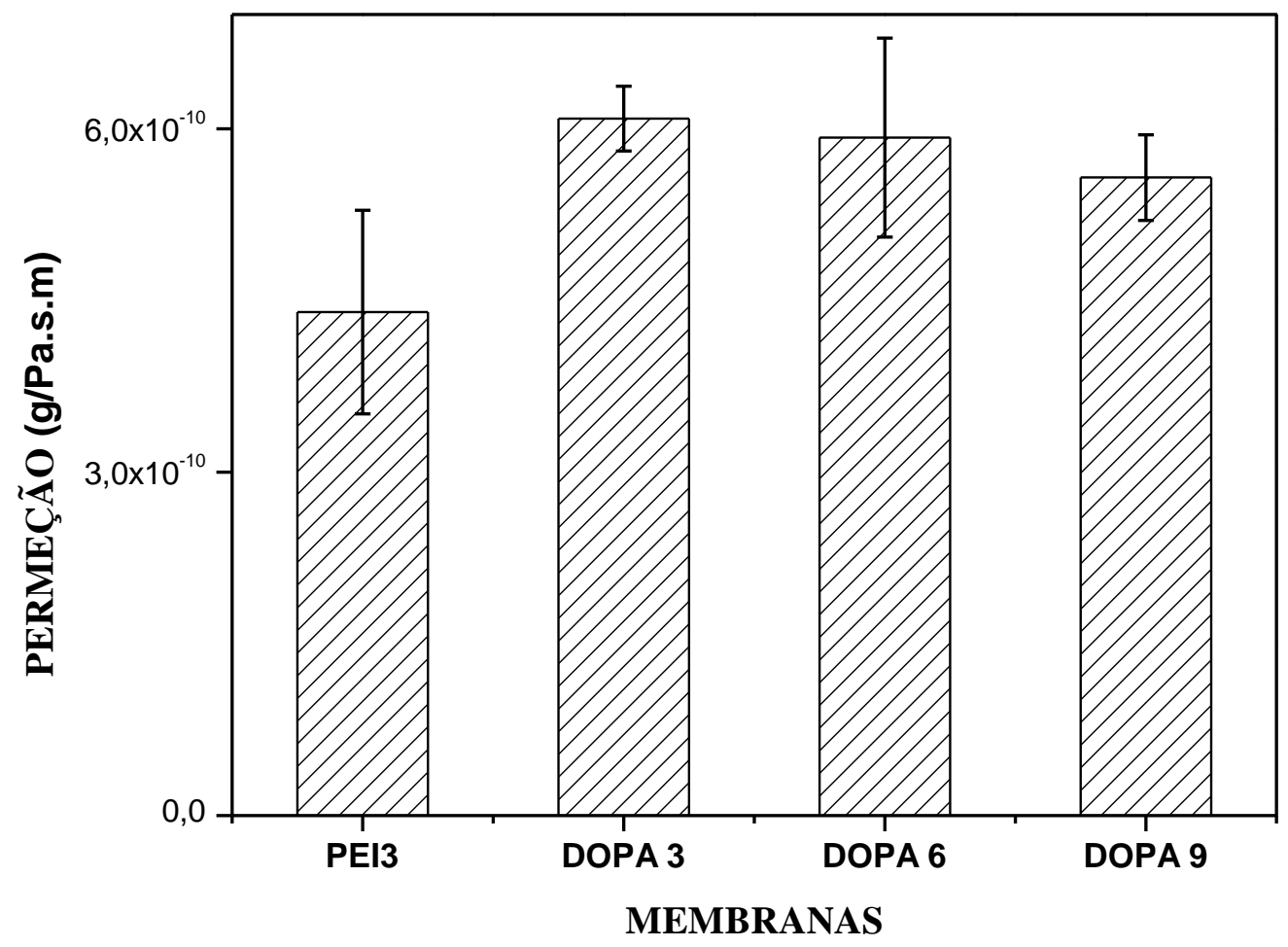

Fonte: Autoria própria

Pode se observar que as membranas de PEI modificadas (recobertas com polidopamina) apresentaram maiores taxas de permeação de vapor de água que a membrana não modificada. 
Este comportamento provavelmente se deve ao caráter hidrofóbico diminuído das membranas modificadas, previamente apontado pelos resultados dos ângulos de contato e energia livres de interação, na seção anterior. O transporte de vapor de água por membranas microporosas ocorre por sorção das moléculas na superfície da membrana e posterior difusão por entre os poros até dessorverem na face oposta. Pode-se sugerir que a presença de grupos polares, como as hidroxilas presentes na estrutura da polidopamina, aumentem as interações polares, promovam a atenuação do caráter hidrofóbico e auxiliem na etapa de sorção de moléculas de água pela superfície. Assim, maior concentração de moléculas sorvidas promoveram a criação de um gradiente de concentração para a etapa da difusão, e resultaram em maior taxa de permeação.

Os resultados obtidos para as análises de permeância dos gases $\mathrm{O}_{2}, \mathrm{CO}_{2}$ e de fator de separação $\mathrm{O}_{2} / \mathrm{CO}_{2}$ estão compilados na Tabela 13.

Tabela 13. Valores de taxa de permeância e de fator de separação $\mathrm{O}_{2}$ e $\mathrm{CO}_{2}$ para membranas de $\mathrm{PEI}$ modificadas e não modificada.

\begin{tabular}{cccc}
\hline \hline Amostra & $\begin{array}{c}\text { Permeância } \mathrm{O}_{2} \\
(\text { GPU) }\end{array}$ & $\begin{array}{c}\text { Permeância CO} \mathbf{~} \\
(\mathbf{G P U})\end{array}$ & $\begin{array}{c}\text { Fator de separação } \\
\mathbf{O}_{2} / \mathbf{C O}_{2}\end{array}$ \\
\hline \hline PEI 3 & $2,99 \pm 1,73$ & $4,86 \pm 2,05$ & $0,59 \pm 0,10$ \\
DOPA 3 & $21,07 \pm 10,10$ & $28,30 \pm 9,60$ & $0,73 \pm 0,11$ \\
DOPA 6 & $21,26 \pm 3,06$ & $23,09 \pm 0,04$ & $0,92 \pm 0,13$ \\
DOPA 9 & $8,41 \pm 6,22$ & $14,40 \pm 2,16$ & $0,56 \pm 0,35$ \\
\hline \hline
\end{tabular}

Nota-se pelos valores de permeância dos gases $\mathrm{O}_{2} \mathrm{e} \mathrm{CO}_{2}$ a tendência de aumento na taxa de permeância de ambos os gases para as membranas modificadas em relação à membrana não modificada. Estes resultados podem ser compreendidos por meio da explicação supracitada, parágrafo referente a permeação de vapor de água, aumento da quantidade de moléculas sorvidas e criação de um gradiente de concentração que impulsiona o processo difusivo. A mesma tendência pôde ser observada em relação ao fator de separação, na comparação entre as membranas DOPA 3 e DOPA 6 e a membrana PEI 3. Nota-se a ocorrência de expressivo aumento na permeância de $\mathrm{O}_{2}$ que aproximou os valores referentes aos dois gases e contribuiu para um maior valor de fator de separação, próximo da unidade. Contudo, materiais que apresentem valores para fator de separação menores que 1 não são designados seletivos. Portanto a modificação de superfície por recobrimento com polidopamina foi capaz de 
aprimorar a permeância do gás $\mathrm{O}_{2}$ de membranas do tipo PEI 3, ao ponto de quase igualar as permeâncias de ambos os gases testados, contudo o objetivo de alcançar a seletividade $\mathrm{O}_{2} / \mathrm{CO}_{2}$ não foi alcançada. 


\section{Conclusão Parcial}

A partir da análise das imagens digitais das membranas, onde foi possível observar características das membranas de PEI antes e depois da modificação bioinspirada, identificouse a deposição da polidopamina, a mudança de coloração das membranas indicou a eficácia do procedimento de auto polimerização. Ficou demonstrado, pelas análises termogravimétricas, presença de substância química capaz de alterar eventos térmicos característicos de PEI, e pela aferição de ângulos de contato entre as membranas e líquidos polares e apolares, a ocorrência de alterações superficiais. Através da obtenção do valor da energia livre de interação das membranas foi possível avaliar o caráter hidrofóbico delas e relacionar esta característica com os resultados de permeação ao vapor de água e de permeância dos gases $\mathrm{O}_{2}$ e $\mathrm{CO}_{2}$. Sendo, as membranas modificadas, menos hidrofóbicas e mais permeáveis.

Foi possível concluir, através do exposto, que a modificação bioinspirada é um método simples e eficaz de deposição de polidopamina, que alterou somente as características de superfície, mantendo a morfologia típica de membrana assimétrica preservada. Que a presença de polidopamina nas membranas as tornam materiais menos hidrofóbicos e com maior capacidade de participar de interações químicas com espécies polares, alterando propriedades como molhabilidade e permeabilidade. 


\section{CONCLUSÃO GERAL E PERSPECTIVAS}

Este trabalho colaborou para reafirmar a eficácia da técnica de Loeb-Sourirajan para a produção de membranas porosas assimétricas, como mostraram as imagens de MEV. Adicionalmente apontou o polímero PEI como material apropriado para produzir as referidas membranas, uma vez que ficaram comprovadas suas estabilidades térmica e química, por meio dos resultados das análises termogravimétricas e espectroscopia na região do infravermelho.

Através do estudo sistemático empregado na etapa de produção das membranas, planejamento fatorial e método de superfície de resposta, foi possível avaliar como diferentes combinações entre os fatores, inerentes ao método de produção, impacta os perfis morfológicos das membranas. Também foi possível compreender que as influências das variáveis são particulares quando avaliadas unicamente ou em sinergia. Ficou demonstrado que um estudo sistemático possibilita controlar as características do produto.

Para além das investigações empregadas na etapa de produção, ficou demostrado que as modificações de superfície são capazes de promover alterações significativas em propriedades importantes dos materiais modificados. As membranas que foram submetidas a modificação bioinspirada demonstraram-se mais hidrofílicas e com maior capacidade de interagir com substância polares, e decorrente desta ampliação de reatividade superficial, pôde-se identificar o aprimoramento das propriedades de transporte destes materiais: permeabilidade ao vapor de água e permeância dos gases $\mathrm{O}_{2}$ e $\mathrm{CO}_{2}$.

A partir do que foi apresentado e discutido nos capítulos I, II e III deste trabalho conclui-se que o emprego de planejamento experimental e modificação superficial, como metodologia, promoveu amplo conhecimento sobre produção e aprimoramento das membranas, pois foi possível conhecer as condições de obtenção e modificações necessárias para se alcançar produto final com características suficientes para aplicações específicas, como sugestão, processos de oxigenação sanguínea. Neste tipo de processo é requerido material filtrante que possuam satisfatórias permeabilidades aos gases $\mathrm{O}_{2}$ e $\mathrm{CO}_{2}$, além de resistência ao acúmulo de espécie orgânicas, fouling, causador do encurtamento da vida útil destes materiais, como dois de seus pré-requisitos. O material desenvolvido no presente trabalho mostrou ser permeável ao gás $\mathrm{O}_{2}$ e apresentou condições de interação polar e apolar em suas faces superficiais, sugerindo boa atividade anti-fouling. 
Contudo, ao se pensar em aplicações na área médica, se faz necessário a realização de estudos complementares visando avaliar bio e hemocompatibilidade,e comprovar atividade anti - fouling, assim como testes de oxigenação sanguínea. Sendo assim, pode-se sugerir que o presente trabalho abre perspectivas para trabalhos futuros. 


\section{REFERÊNCIAS}

AHMAD, A. L.; OLATUNJI, S. Y.; JAWAD, Z. A. Thickness effect on the morphology and permeability of $\mathrm{CO}_{2} / \mathrm{N}_{2}$ gases in asymmetric polyetherimide membrane. Journal of Physical Science, Penang, v. 28, p. 201-213, 2017.

AHMAD, A. L.; SALAUDEEN, Y. O.; JAWAD, Z. A. Synthesis of asymmetric polyetherimide membrane for $\mathrm{CO}_{2} / \mathrm{N}_{2}$ separation. IOP Conference Series: materials science and engineering, Bristol, v. 206, n. 1, 2017.

AINSCOUGH, T. J.; OATLEY-RADCLIFFE, D. L.; BARRON, A. R. Parametric optimisation for the fabrication of polyetherimide-sPEEK asymmetric membranes on a nonwoven support layer. Separation and Purification Technology, Oxford, v. 186, p. 78-89, 2017.

ALQAHEEM, Y.; ALOMAIR, A. Recent developments in polyetherimide membrane for gas separation. Journal of the Chinese Chemical Society, Taipei, v. 66, n. 12, p. 1738-1744, 2019.

AMANCIO-FILHO, S. T.; ROEDER J.; NUNES S.P.; DOS SANTOS J.F.; BECKMANN F. Thermal degradation of polyetherimide joined by friction riveting (FricRiveting). Part I: Influence of rotation speed. Polymer Degradation and Stability, London, v. 93, n. 8, p. 1529-1538, 2008.

AMERICAN SOCIETY FOR TESTING AND MATERIALS. ASTM E 96: standard test methods for water vapor transmission of materials. West Conshohocken, 2017.

AMERICAN SOCIETY FOR TESTING AND MATERIALS. ASTM D 5725: standard test method for surface wettability and absorbency of sheeted materials using an automated contact angle tester. West Conshohocken, 2008.

ASHLAND. Pharmasolve ${ }^{\text {TM }}$ N-methyl-2-pyrrolidone chemistry: intermediates and solvents. Wilmington, [2020]. Disponível em:

https://www.ashland.com/industries/pharmaceutical/oral-solid-dose/pharmasolve-n-methyl-2pyrrolidone. Acesso em: 17 mar. 2020.

BAKER, R. W. Membrane technology and application. 2. ed. Chichester: John Wiley and Sons, 2001.

BAKERI, Gh; ISMAIL, A.F.; SHARIATY-NIASSAR, M.; MATSUURA, T. Effect of polymer concentration on the structure and performance of polyetherimide hollow fiber membranes. Journal of Membrane Science, Amsterdam, v. 363, n. 1-2, p. 103-111, 2010.

BAKERI, Gh.; MATSUURA, T.; ISMAIL, A.F.; RANA, D. A novel surface modified polyetherimide hollow fiber membrane for gas-liquid contacting processes. Separation and Purification Technology, Oxford, v. 89, p. 160-170, 2012. 
BAKERI, Gh.; ISMAIL, A.F.; RAHIMNEJAD, M.; MATSUURA, T. Porous polyethersulfone hollow fiber membrane in gas-liquid contacting processes. Chemical Engineering Research and Design, London, v. 92, n. 7, p. 1381-1390, 2014.

BAKERI, G.; MATSUURA, T.; ISMAIL, A. F. The effect of phase inversion promoters on the structure and performance of polyetherimide hollow fiber membrane using in gas-liquid contacting process. Journal of Membrane Science, Amsterdam, v. 383, n. 1-2, p. 159-169, 2011.

BURZIO, L. A.; WAITE, J. H. Cross-linking in adhesive quinoproteins: studies with model decapeptides. Biochemistry, Washington, v. 39, n. 36, p. 11147-11153, 2000.

CARROCCIO, S.; PUGLISI, C.; MONTAUDO, G. Thermal degradation mechanisms of polyetherimide investigated by direct pyrolysis mass spectrometry. American Chemical Society, Polymer Preprints, Division of Polymer Chemistry, Blacksburg, v. 41, n. 1, p. 684-685, 2000.

CHAPMAN, C. L.; BHATTACHARYYA, D.; EBERHART, T.R.; TIMMONS, R.B.; CHUONG, C. Plasma polymer thin film depositions to regulate gas permeability through nanoporous track etched membranes. Journal of Membrane Science, Amsterdam, v. 318, n. 1-2, p. 137-144, 2008.

CHEN, X. Y; VINH-THANG, H.; RAMIREZ, A.A.; RODRIGUE, D.; KALIAGUINES, S. Membrane gas separation technologies for biogas upgrading. RSC Advances, Cambridge, v. 5, p. 24399-24448, 2015.

DE BARROS NETO B., SCARMINIO I S., BRUNS, B. R. E. Como fazer experimentos: pesquisa e desenvolvimento na pesquisa e na indústria. 2. ed. Campinas: Editora UniCamp, 2001.

DREYER, D. R.; MILLER, D.J.; FREEMAN , B.D.; PAUL, D.R.; BIELAWSKI, C.W. Elucidating the structure of poly(dopamine). Langmuir, Washington, v. 28, n. 15, p. 64286435, 2012.

GEORGE, G.; BHORIA, N; ALHALLAQ, S.; ABDALA, A.; MITTAL, V. Polymer membranes for acid gas removal from natural gas. Separation and Purification Technology, Oxford, v. 158, p. 333-356, 2016.

GOVARDHAN, B.; CHANDRASEKHAR, S. S.; SRIDHAR, S. Purification of surface water using novel hollow fiber membranes prepared from polyetherimide/polyethersulfone blends. Journal of Environmental Chemical Engineering, Amsterdam, v. 5, n. 1, p. 1068-1078, 2017.

HASHEMIFARD, S. A.; ISMAIL, A. F.; MATSUURA, T. Co-casting technique for fabricating dual-layer flat sheet membranes for gas separation. Journal of Membrane Science, Amsterdam, v. 375, n. 1-2, p. 258-267, 2011.

HASHEMIFARD, S. A.; ISMAIL, A. F.; MATSUURA, T. To what extent the conventional gas permeation testing method is reliable for membrane systems? Separation and

Purification Technology, Oxford, v. 114, p. 90-98, 2013. 
JIANG, J.-H.; ZHU, L.-P.; LI, X.-L.; XU, Y.-Y.; ZHU, B.-K. Surface modification of PE porous membranes based on the strong adhesion of polydopamine and covalent immobilization of heparin. Journal of Membrane Science, Amsterdam, v. 364, n. 1-2, p. 194-202, 2010.

KURDI, J.; TREMBLAY, A. Y. Preparation of defect-free asymmetric membranes for gas separations. Journal of Applied Polymer Science, Hoboken, v. 73, n. 8, p. 1471-1482, 1999.

KWOK, D. Y.; GIETZELT, T.; GRUNDKE, K.; JACOBASCH, H.-J.; NEUMANN, A.W. Contact angle measurements and contact angle interpretation: 1. Contact angle measurements by axisymmetric drop shape analysis and a goniometer sessile drop technique. Langmuir, Washington, v. 13, n. 10, p. 2880-2894, 1997.

KWOK, D. Y.; NEUMANN, A. W. Contact angle measurement and contact angle interpretation. Advances in Colloid and Interface Science, Amsterdam, v. 81, p. 167-249, 1999.

LAGUTSCHENKOV, A.; LANGER, J.; BERDENG, G.; OOMENS, J.; DOPFER,O. Infrared spectra of protonated neurotransmitters: dopamine. Physical Chemistry Chemical Physics, Cambridge, v. 13, n. 7, p. 2815-2823, 2011.

LEE, H.; DELLATORE, S.M.; MILLER, W. M.; MESSERSMITH, P. B. Mussel-inspired surface chemistry for multifunctional coatings. Science, Washington, v. 318, n. 5849, p. 426430, 2007.

LEE, H.; LEE, B. P.; MESSERSMITH, P. B. A reversible wet / dry adhesive inspired by mussels and geckos. Nature, London, v. 448, p. 338-342, 2007.

LEE, H.; SCHERER, N. F.; MESSERSMITH, P. B. Single-molecule mechanics of mussel adhesion. Proceedings of the National Academy of Sciences of the United States of America, Washington, v. 103, n. 35, p. 12999-13003, 2006.

LI, D. CHUNG, T.-S.; REN, J; WANG, R. Thickness Dependence of Macrovoid Evolution in Wet Phase-Inversion Asymmetric Membranes. Industrial and Engineering Chemistry Research, Washington, v. 43, n. 6, p. 1553-1556, 2004.

LI, J.; YUAN, S.; WANG, J.; ZHU, J.; SHEN, J.; VAN der BRUGGEN, B. Mussel-inspired modification of ion exchange membrane for monovalent separation. Journal of Membrane Science, Amsterdam, v. 553, p. 139-150, 2018.

THAKUR, V.K.; LIN, M.-F.; TAN, E.J.; LEE, P.S. Green Aqueous Modification of Fluoropolymers for Energy Storage. Journal of Material Chemistry, Cambridge, v. 22, p. 5951-5959, 2012.

LÓPEZ, T. et al. Treatment of parkinson's disease: Nanostructured sol-gel silica-dopamine reservoirs for controlled drug release in the central nervous system. International Journal of Nanomedicine, Auckland, v. 6, n. 1, p. 19-31, 2011. 
MAHAJAN, R.; KOROS, W. J.; THUNDYIL, M. Mixed matrix membranes: important and challenging! Membrane Technology, Oxford, n. 105, p. 6-8, 1999.

MULDER, M. Basic principles of membranes technology. [S. l.]: Springer, 1992. 374p.

MULTI CHEMIE. N-Metil pirrolidona. FISPQ048: Ficha de informação de segurança de produto químico. São Paulo, 2011. Disponível em:

https://multichemie.com.br/assets/img/pdf/0b588d88e94272f080d37bfbfe8934cc.pdf. Acesso em: 25 mar. 2020.

NAIM, R.; ISMAIL, A. F. Effect of polymer concentration on the structure and performance of PEI hollow fiber membrane contactor for $\mathrm{CO}_{2}$ stripping. Journal of Hazardous

Materials, Amsterdam, v. 250-251, p. 354-361, 2013.

NIKPOUR, N.; KHOSHNEVISAN, B. Enhanced selectivity of $\mathrm{O}_{2} / \mathrm{N}_{2}$ gases in co-casted mixed matrix membranes filled with $\mathrm{BaFe}_{12} \mathrm{O}_{19}$ nanoparticles. Separation and Purification Technology, Oxford, v. 242, p. 116815, 2020.

NORADRENALINA, $\mathrm{C}_{8} \mathrm{H}_{11} \mathrm{NO}_{3}$. Química Nova Interativa. São Paulo, [201-?]. Disponível em:

http://qnint.sbq.org.br/qni/popup_visualizarMolecula.php?id=A_3wEphgIKdNJPdfpgLli2c4I doShPwAGVPr65nAURp6Buw-v5W-cbSIBtfu22aXCezfvV1R6MGpNLOtJPYeKg==.

Acesso em: 25 mar. 2020.

PEREIRA FILHO, E. R. Planejamento fatorial em química: maximizando a obtenção de resultados. São Carlos: EdUFSCar, 2015. 88 p.

QTAISHAT, M.; RANA, D.; KHAYET, M.; MATSUURA, T. Preparation and characterization of novel hydrophobic/hydrophilic polyetherimide composite membranes for desalination by direct contact membrane distillation. Journal of Membrane Science, Amsterdam, v. 327, n. 1-2, p. 264-273, 2009.

RANGARAJAN, R.; MAZID, M. A.; MATSUURA, T.; Sourirajan, S. Permeation of Pure Gases under Pressure through Asymmetric Porous Membranes. Membrane Characterization and Prediction of Performance. Industrial and Engineering Chemistry Process Design and Development, Washington, v. 23, n. 1, p. 79-87, 1984.

RESINEX. Sabic innovative plastics. Braga, [2020]. Disponível em: https://www.resinex.pt/produtores/sabic-ip.html. Acesso em: 2 mar. 2020.

REUVERS, A. J. Formation of membranes by means of immersion precipitation. 1957. Tese (Doutorado em Ciências) - University of Twente, Amersfoort, 1957.

SABIC. ULTEM resins. Riyadh, 2020. Disponível em: https://www.sabic.com/en/products/specialties/ultem-resins/ultem-resin?grade=1010m. Acesso em: 3 out. 2020. 
SAEDI, S.; MADAENI, S. S.; SEIDI, F.; SHAMSABADI, A. A.; LAKI, S. Fixed facilitated transport of $\mathrm{CO}_{2}$ through integrally-skinned asymmetric polyethersulfone membrane using a novel synthesized Poly (acrylonitrile-co-N, N-Dimethylaminopropyl acrylamide). Chemical Engineering Journal, Amsterdam, v. 236, p. 263-273, 2014.

SAEDI, S.; MADAENI, S. S.; SHAMSABADI, A. A. Fabrication of asymmetric polyethersulfone membranes for separation of carbon dioxide from methane using polyetherimide as polymeric additive. Chemical Engineering Research and Design, London, v. 92, n. 11, p. 2431-2438, 2014.

SCHOFIELD, R. W.; FANE, A. G.; FELL, C. J. D. Gas and vapour transport through microporous membranes. I. Knudsen-Poiseuille transition. Journal of Membrane Science, Amsterdam, v. 53, n. 1-2, p. 159-171, 1 out. 1990.

SHAMSABADI, A. A.; KARGARI, A.; BABAHEIDARI, M. B.; LAKI, S.; AJAMI, H. Role of critical concentration of PEI in NMP solutions on gas permeation characteristics of PEI gas separation membranes. Journal of Industrial and Engineering Chemistry, Amsterdam, v. 19, n. 2, p. 677-685, $2013 \mathrm{a}$.

SHAMSABADI, A. A.; KARGARI, A.; BABAHEIDARI, M. B.; LAKI, S.. Separation of hydrogen from methane by asymmetric PEI membranes. Journal of Industrial and Engineering Chemistry, Amsterdam, v. 19, n. 5, p. 1680-1688, 2013 b.

SILVERMAN, H. G.; ROBERTO, F. F. Understanding marine mussel adhesion. Marine Biotechnology, New York, v. 9, n. 6, p. 661-681, 2007.

TIEN-BINH, N.; VINH-THANG, H.; YUAN, X. Crosslinked MOF-polymer to enhance gas separation of mixed matrix membranes. Journal of Membrane Science, Amsterdam, v. 520, p. 941-950, 2016.

TOMÉ, L. C.; ISIK, M.; FREIRE, C. S. R.; MECERREYES, D.; MARRUCHO, I. M. Novel pyrrolidinium-based polymeric ionic liquids with cyano counter-anions: HIGH performance membrane materials for post-combustion $\mathrm{CO}_{2}$ separation. Journal of Membrane Science, Amsterdam, v. 483, p. 155-165, 2015.

UENISHI, M.; FUKUSHIMA, N.; MIZUTA, M.; KAMO, J.; TSURU, T. Gas-permeable composite hollow-fiber membrane with a three-layered structure. Journal of Membrane Science, Amsterdam, v. 467, p. 175-187, 2014.

URIARTE, C.; ALFAGEME, J.; IRUIN, J. J. Carbon dioxide transport properties of composite membranes of a polyetherimide and a liquid crystal polymer. European Polymer Journal, Oxford, v. 34, n. 10, p. 1405-1413, 1998.

VAN DE WITTE, P.; DIJKSTRA, P. G.; VAN DEN BERG, J.W.A.; FEIJEN, J. Phase separation processes in polymer solutions in relation to membrane formation. Journal of Membrane Science, Amsterdam, v. 117, n. 1-2, p. 1-31, 1996. 
VAN OSS, C. J. Hydrophobicity of biosurfaces: origin, quantitative determination and interaction energies. Colloids and Surfaces B: biointerfaces, Amsterdam, v. 5, n. 3-4, p. 91$110,1995$.

VAN OSS, C. J.; CHAUDHURY, M. K.; GOOD, R. J. Interfacial Lifshitz - van der Waals and Polar Interactions in Macroscopic Systems. Chemical Reviews, Washington, v. 88, n. 6, p. 927-941, 1988.

VEDOVELLO, P. Correlação estrutura x propriedades de transporte de $\mathrm{CO}_{2} \mathrm{em}$ membranas de poli(éterimida)/líquido iônico. 2017. Dissertação (Mestrado em FísicoQuímica) - Departamento de Química, Universidade Federal de São Carlos, São Carlos, 2017.

WANG, T.; QIBLAWEY, H.; SIVANIAH, E.; MOHAMMADIAN, A. Novel methodology for facile fabrication of nanofiltration membranes based on nucleophilic nature of polydopamine. Journal of Membrane Science, Amsterdam, v. 511, p. 65-75, 2016.

WANG, Y. B.; GONG, M.; YANG, S.; NAKASHIMA, K.; GONG, Y. -K. Hemocompatibility and film stability improvement of crosslinkable MPC copolymer coated polypropylene hollow fiber membrane. Journal of Membrane Science, Amsterdam, v. 452, p. 29-36, 2014.

WIENK, I. M.; BOOM, R. M.; BEERLAGE, M. A. M.; BULTE, A. M. W.; SMOLDERS, C. A.; STRATHMANN, H. Recent advances in the formation of phase inversion membranes made from amorphous or semi-crystalline polymers. Journal of Membrane Science, Amsterdam, v. 113, n. 2, p. 361-371, 1996.

XI, Z. -Y.; XU, Y. -Y.; ZHU, L. -P.; WANG, Y.; ZHU, B. -K. A facile method of surface modification for hydrophobic polymer membranes based on the adhesive behavior of poly(DOPA) and poly(dopamine). Journal of Membrane Science, Amsterdam, v. 327, n. 12, p. 244-253, 2009.

XU, Y.; LI, Z.; SU, K.; FAN, T.; CAO, L. Mussel-inspired modification of PPS membrane to separate and remove the dyes from the wastewater. Chemical Engineering Journal, Amsterdam, v. 341, n. February, p. 371-382, 2018.

YANG, E.; GOH, K.; CHUAH, C. Y.; WANG, R.; BAE, T. -H. Asymmetric mixed-matrix membranes incorporated with nitrogen-doped graphene nanosheets for highly selective gas separation. Journal of Membrane Science, Amsterdam, v. 615, p. 118293, 2020.

YILDIRIM ERBIL, H.; MCHALE, G.; ROWAN, S. M.; NEWTON, M. I. Determination of the receding contact angle of sessile drops on polymer surfaces by evaporation. Langmuir, Washington, v. 15, n. 21, p. 7378-7385, 1999.

YU, M.; HWANG, J.; DEMING, T. J. Role of L-3,4-Dihydroxyphenylalanine in mussel adhesive proteins. Journal of the American Chemical Society, Washington, v. 121, n. 24, p. 5825-5826, 1999. 
ZULHAIRUN, A. K.; Ng, B.C.; ISMAIL, A .F.; SURYA MURALI, R.; ABDULLAH, M.S. Production of mixed matrix hollow fiber membrane for $\mathrm{CO}_{2} / \mathrm{CH}_{4}$ separation. Separation and Purification Technology, Oxford, v. 137, p. 1-12, 2014. 